\title{
Fragipan influence on hydropedological properties of benchmark soilscapes in West Virginia
}

John F. Beck

West Virginia University

Follow this and additional works at: https://researchrepository.wvu.edu/etd

\section{Recommended Citation}

Beck, John F., "Fragipan influence on hydropedological properties of benchmark soilscapes in West Virginia" (2011). Graduate Theses, Dissertations, and Problem Reports. 3392.

https://researchrepository.wvu.edu/etd/3392

This Dissertation is protected by copyright and/or related rights. It has been brought to you by the The Research Repository @ WVU with permission from the rights-holder(s). You are free to use this Dissertation in any way that is permitted by the copyright and related rights legislation that applies to your use. For other uses you must obtain permission from the rights-holder(s) directly, unless additional rights are indicated by a Creative Commons license in the record and/ or on the work itself. This Dissertation has been accepted for inclusion in WVU Graduate Theses, Dissertations, and Problem Reports collection by an authorized administrator of The Research Repository @ WVU.

For more information, please contact researchrepository@mail.wvu.edu. 
FRAGIPAN INFLUENCE ON HYDROPEDOLOGICAL PROPERTIES OF BENCHMARK SOILSCAPES IN WEST VIRGINIA

\author{
John F. Beck
}

Dissertation submitted to the College of Agriculture, Natural Resources and Design at West Virginia University in partial fulfillment for the requirements for the degree of

Doctor of Philosophy in Plant and Soil Sciences

Committee:

Dr. James A. Thompson, Chair

Dr. Steven Kite

Dr. Eugenia M. Pena-Yewtukhiw

Dr. Michael Strager

Dr. Nicolas Zegre

Division of Plant and Soil Sciences

Morgantown, WV 


\begin{abstract}
Fragipan Influence on Hydropedological Properties of Benchmark Soilscapes in West Virginia
\end{abstract}

John F. Beck

Soil wetness and the interactions between soil and water influence the potential uses of soil and must be considered when making decisions regarding soil use and management. The strategic placement of hydrologic monitoring instrumentation on a benchmark soilscape is critical toward providing the users of soil information with reliable predictability of water movement at the soil-water interface.

A hydropedologically significant study site that satisfies the benchmark soilscape criteria as defined by the Natural Resources Conservation Service (NRCS) was selected for this research. Because of the high cost of performing investigations and research, benchmark soils are targeted and the information gleaned from those studies is extrapolated to other like regions. The area of this research consists of a 53 ha catchment located approximately $15 \mathrm{~km}$ east of Morgantown, West Virginia in Coopers Rock State Forest. The catchment is in a mature deciduous forest in Major Land Resource Area 127.

Piezometric data confirm that the depth to the water is consistent with the first encounter of redoximorphic depletions as identified in the soil profile descriptions. Results reveal that water is present in the layer immediately above the fragipan zone at all hillslope locations with the exception of the backslope, at which results are mixed and can be attributed to the sub-landforms commonly encountered across the backslope. As hypothesized, the footslope location exhibits a higher frequency and duration of saturation than any other position on the hillslope. 


\section{Acknowledgements}

This dissertation is the culmination of ideas nurtured by a community of professionals dedicated to their respective fields. This work would not have been possible without the input of many others whom I would like to mention here.

First, I would like to thank Dr. James Thompson for his guidance throughout this project, without which this work would still be untested ideas in my head. His guidance and confidence in my ability to find the right solution to a multitude of issues has given me confidence in myself as I move further into a career in soil science.

I would to thank the members of my committee for not only making themselves available, but for challenging me along the way. A sincere thank you goes to Dr. Steve Kite, Dr. Eugenia Pena-Yewtukhiw, Dr. Michael Strager, and Dr. Nicolas Zegre for their time and willingness to discuss this project as well as the many related topics. Their dedication and commitment to this project, as well as to me individually, has been outstanding.

I would like to thank the other faculty in the Division of Plant and Soil Sciences who have also taken considerable time to answer questions and offer suggestions. In no particular order I thank Dr. Louis McDonald, Dr. Jeffrey Skousen, and Dr. Barton Baker for their input into my project as well as toward my development as a graduate student and professional in the field of soil science. I also thank Dr. Henry Lin at Pennsylvania State University for assistance and guidance with the installation of the soil monitoring probes.

I want to thank my NRCS "family" for all of their effort toward the success of this project and their interest in me as a person. Thank you to Minnesota and West Virginia. The list is too exhaustive to mention everyone (mostly, I fear I will inadvertently leave someone out as there are so many), but I especially appreciate the extra effort provided by the MLRA Soil Survey leader Skip Bell and soil scientists Wendy Noll and Aron Sattler for their input into the site selection and further assistance and consultation throughout the project. I also want to thank soil scientist Steve Carpenter as the MO13 office for supporting this research project. From the National Soil Survey Center I would like to thank the director, Jon Hempel for the opportunity afforded me to attend graduate school at West Virginia University. From the Geospatial Research Unit in Morgantown a special thank you to: data analyst, Darrell Kautz and soil scientists, Sharon Waltman, Tom D’Avello, Henry Ferguson, and Amanda Moore, whose expertise and dedication to the field of soil science is unsurpassed.

Finally, I would like to thank all of my fellow graduate students who have helped me in this project and/or to be a successful graduate student including: Mike Harman, Rishi Prasad, Travis Keene, Curtiss DeLong, Sriroop Chaudhuri, Mimi Roy, Mike Mara, Calene Thomas, and Donglin Huang. And finally, I thank Tara Matheny, Katey Buckland, and Aaron Burkholder for field assistance and/or some laboratory analyses. 
Table of Contents

1. Introduction and Literature Review ........................................................ 1

1.1. Soil Morphology and Hydrology ................................................................ 1

1.2. Soil Classification and Soil Survey ............................................................ 3

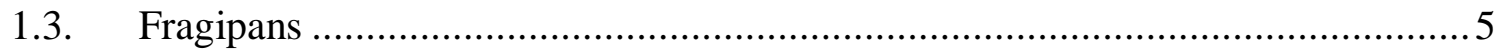

1.4. Linking Pedology and Hydrology into a Hydropedological Approach ............... 9

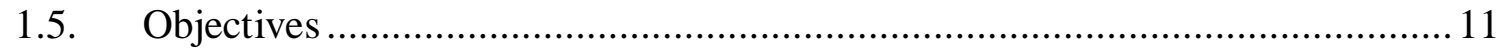

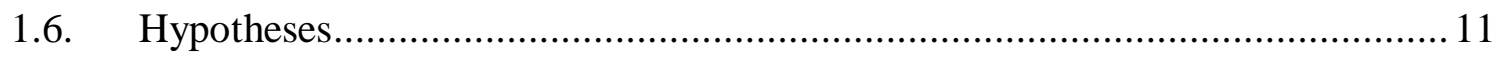

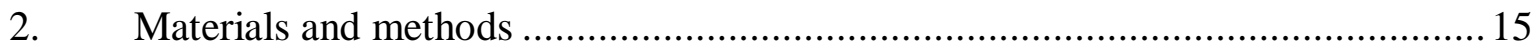

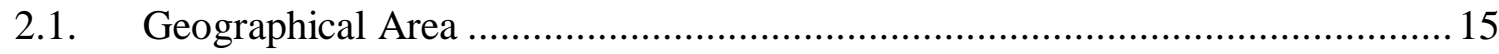

2.2. Site Description.................................................................................... 17

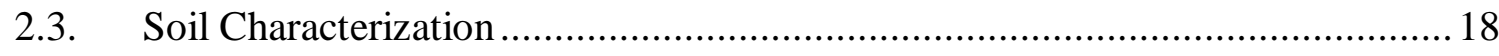

2.3.1. Soil Characterization Sampling ..................................................... 21

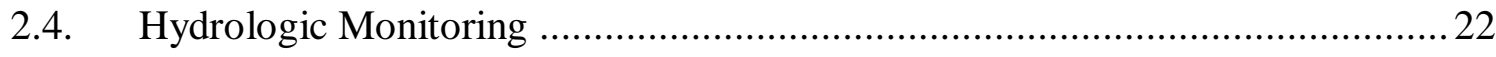

2.4.1. Volumetric Water Content and Soil Temperature .............................. 23

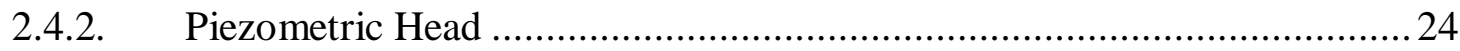

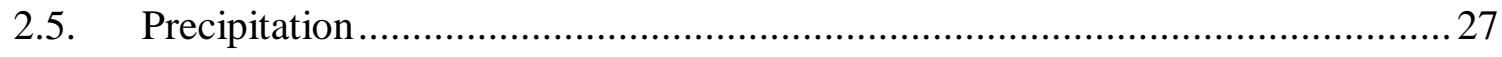

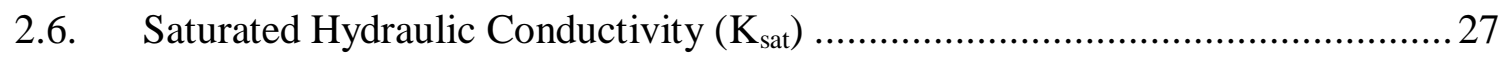

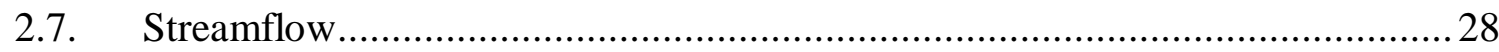

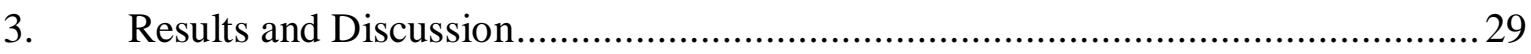

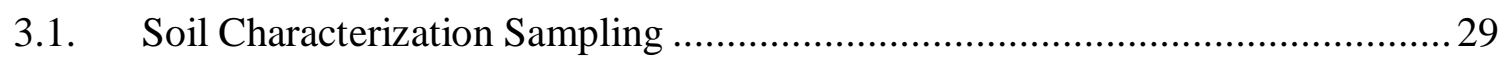

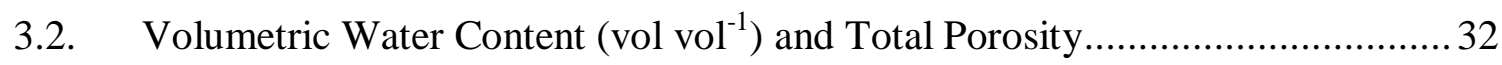

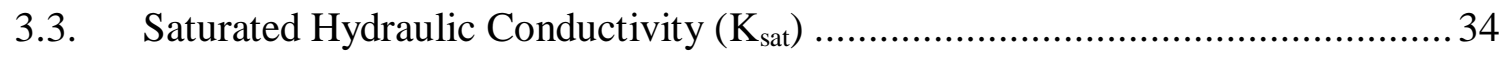

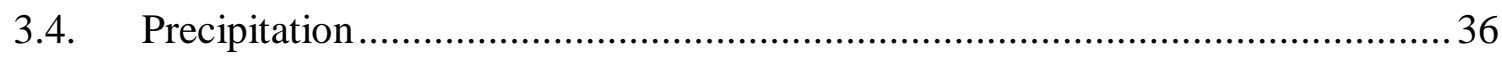

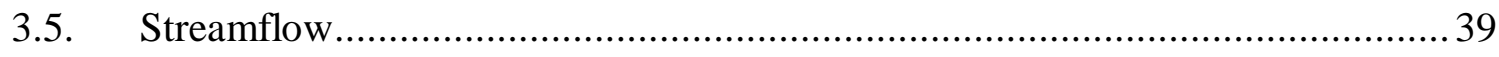

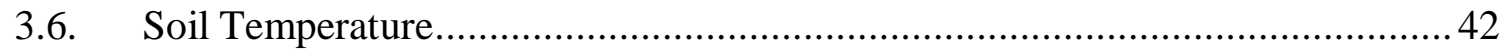

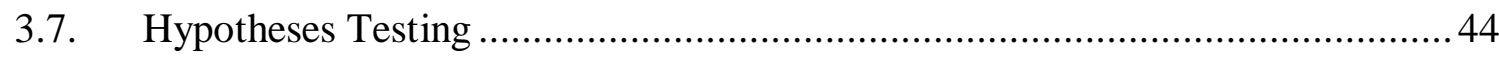

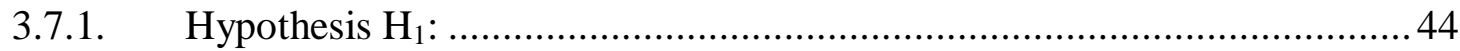

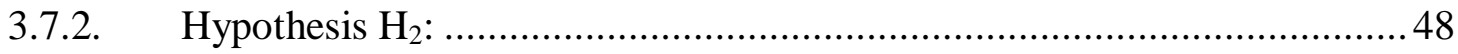

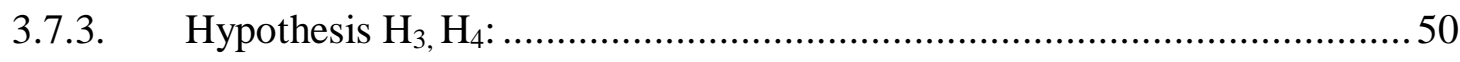

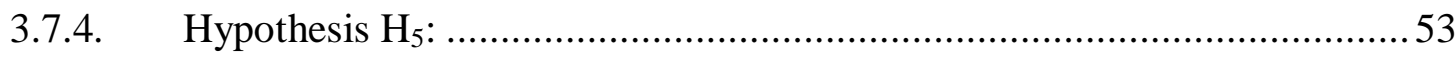




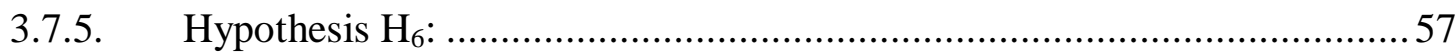

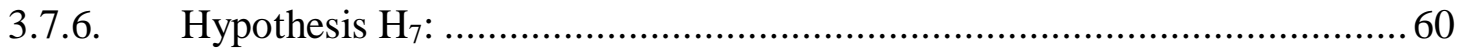

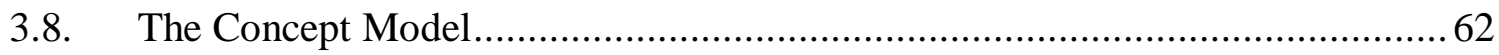

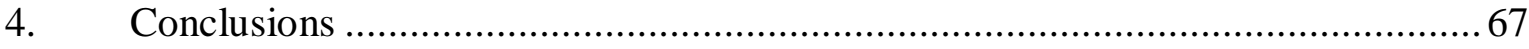

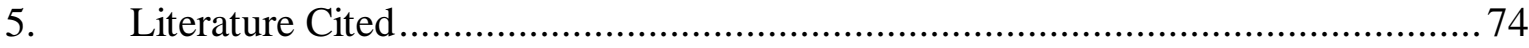

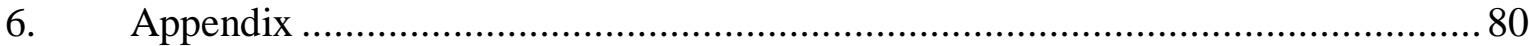

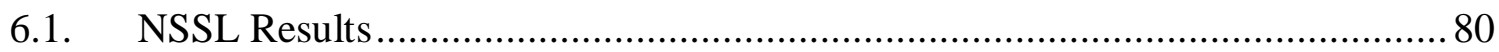

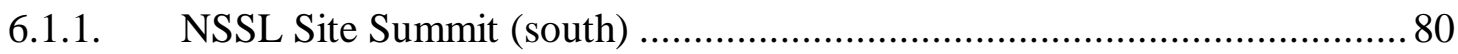

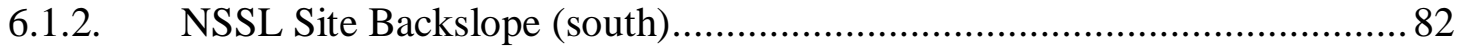

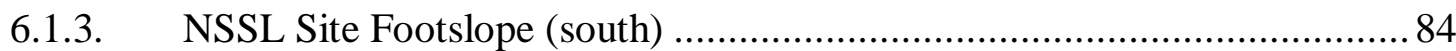

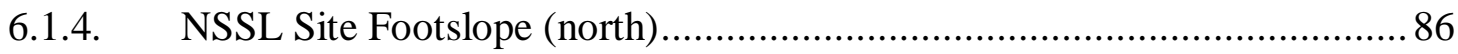

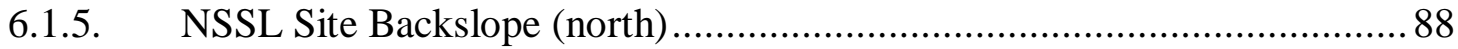

6.1.6. NSSL Site Summit (north) ..................................................................... 91

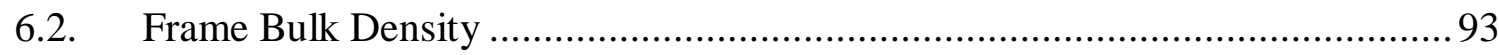

6.2.1. Frame Bulk Density Site Summit (south).................................................. 93

6.2.2. Frame Bulk Density Site Backslope (south) ............................................... 94

6.2.3. Frame Bulk Density Site Footslope (south)................................................ 95

6.2.4. Frame Bulk Density Site Footslope (north) ................................................96

6.2.5. Frame Bulk Density Site Backslope (north) ............................................... 97

6.2.6. Frame Bulk Density Site Summit (north) ................................................... 98

6.3. Schema of Sensors/Probes Installation ………................................................. 99

6.3.1. Schema of Sensors/Probes Site Summit (south) .........................................99

6.3.2. Schema of Sensors/Probes Site Backslope (south) .................................... 100

6.3.3. Schema of Sensors/Probes Site Footslope (south) ……………................. 100

6.3.4. Schema of Sensors/Probes Site Footslope (north) .................................... 101

6.3.5. Schema of Sensors/Probes Site Backslope (north) ................................... 101

6.3.6. Schema of Sensors/Probes Site Summit (north) ....................................... 102

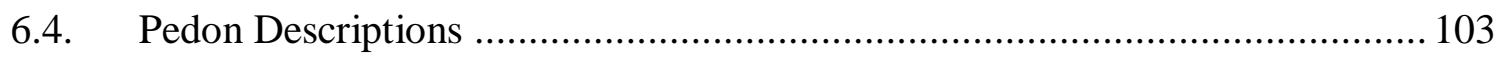

6.4.1. Pedon Description Site Summit (south) ................................................... 103

6.4.2. Pedon Description Site Backslope (south) ………………….................... 106

6.4.3. Pedon Description Site Footslope (south) …………………………........ 109 
6.4.4. Pedon Description Site Footslope (north)........................................ 112

6.4.5. Pedon Description Site Backslope (north) ....................................... 115

6.4.6. Pedon Description Site Summit (north).......................................... 118 


\section{List of Tables}

Table

Page \#

Table 2-1: Horizon and depth of installed nested-piezometers by hillslope position. .......26

Table 3-1: Selected properties of the soils by hillslope location.................................. 30

Table 3-2: USDA saturated hydraulic conductivity $\left(\mathrm{K}_{\text {sat }}\right)$ classes. .............................. 35

Table 3-3: Precipitation ( $\mathrm{mm}$ ) recorded at the CRSF-WS and the hillslope gauges for the 2010 calendar year. Temperature data is from the CRSF-WS for the same time

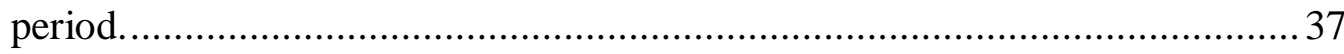

Table 3-4: Precipitation differences (\%) between hillslope gauges and the CRSF-WS for the summer period (May through October) for 2010. Positive values indicate higher precipitation was recorded at the hillslope gauges............................. 38

Table 3-5: The average of all hillslope rain gauges compared to the CRSF-WS. A positive $\%$ difference reflects higher average precipitation recorded by the hillslope gauges. Negative \% difference values reflect lower average precipitation recorded by the hillslope gauges. Data are May through October, 2010........ 38

Table 3-6: Stream stage $(\mathrm{cm})$ and corresponding monthly average discharge $\left(\mathrm{L} \mathrm{s}^{-1}\right)$ for the length of the study.

Table 3-7: Comparison of the fragipan vs. the paralithic contact soil to the nine storm events for the 2010 calendar year. 


\section{List of Figures}

Figure

Page \#

Figure 2-1: Geographic extent of MLRA 127 in the continental U.S. The location of the study area is indicated by the yellow triangle.

Figure 2-2: The study area is located in north-central West Virginia approximately $15 \mathrm{~km}$ ( $~ 9 \mathrm{mi}$ ) east of Morgantown.

Figure 2-3: The study area consists of a 53 ha $(131 \mathrm{ac})$ catchment. The soils map (Soil Survey Staff, 2008) of the study area includes the benchmark soil series of Buchanan and Tilsit (BeC and TlB respectively). Also mapped is the Dekalb soil series (DaB, DaC, DdC, and DdE).

Figure 2-4: Schema of the hydrologic monitoring probes installed at the Summit (south) location.

Figure 2-5: Each aspect-paired hillslope position was instrumented with a set of nested piezometers

Figure 3-1: Stream stage hydrograph of the 21 months of observation. (Data shown are August 2009 through April 2011. Data is unavailable for December 17, 2010 through February 19, 2011.)

Figure 3-2: Volume flow rate $\left(\mathrm{L} \mathrm{s}^{-1}\right)$ was determined at various stream stages $(\mathrm{cm})$ using salt tracers. The linear regression equation is: $y=0.48 \mathrm{x}+1.85 ; \mathrm{r}^{2}=0.91$. The explanatory variable is the stage $(\mathrm{cm})$ of water recorded throughout the duration of the study.

Figure 3-3: Mean monthly, near surface soil temperature at hillslope location. (Data shown are 2010 calendar year)

Figure 3-4: Mean monthly soil temperature used to derive mean annual soil temperature (MAST) used in soil classification by hillslope location. (Data shown are 2010 calendar year)

Figure 3-5: Daily average thickness of water perching above the fragipan as measured at the Summit (south) hillslope location.

Figure 3-6: Daily average thickness of water perching above the fragipan as measured at the Footslope (south) hillslope location.

Figure 3-7: Daily average thickness of water perching above the fragipan as measured at the Footslope (north) hillslope location.

Figure 3-8: Percent of the sum of thickness of water recorded at the deepest piezometers by hillslope location.

Figure 3-9: Percent saturation of the fragipan horizon comparisons at hillslope locations.

Figure 3-10: Daily average thickness of water observed in deep piezometers as measured at the backslope hillslope locations. 
Figure 3-11: Daily average thickness of water observed in deep piezometers as measured at the footslope hillslope locations.

Figure 3-12: Daily average thickness of water observed in the deep piezometers as measured at all hillslope locations.

Figure 3-13: Daily average thickness of water perching above the fragipan or paralithic contact at all locations.

Figure 3-14: Thickness of water perching at slope curvature. 61

Figure 3-15: The Concept Model of water perching in winter. Depicted are two separate perching water tables. 1a-Water perched above the fragipan at the summit. $1 \mathrm{~b}$-Water perched above the fragipan at the footslope. 2a-Water perched above the paralithic contact beneath the fragipan at the summit. 2b- Water perched above the paralithic contact at the non-fragipan summit. 2c-Water perched above the paralithic contact beneath the fragipan at the footslope. 3A small amount of water may be perched at the contact with the underlying bedrock

Figure 3-16: The Concept Model of water perching in summer. 1-Water perched above the paralithic contact beneath the fragipan at the summit. 2-Water perched above the paralithic contact beneath the fragipan at the footslope. 


\section{Introduction and Literature Review}

\subsection{Soil Morphology and Hydrology}

Soil wetness and the interactions between soil and water influence the potential uses of the soil, and must be considered when making decisions regarding land use and management. Shallow water tables may cause homeowners to experience failing septic drain fields or wet basements. Farmers may experience severe compaction on grazing land if stocking rates are too high or if timing of grazing is such that livestock are put to pasture during wet periods. Compaction caused by heavy machinery during wet periods in cropped fields and forest logging roads and landing settings is also a management concern. These and other issues speak to a need for accurate and precise information on soil- and site-specific hydrologic and hydromorphic soil properties that can be used to formulate reliable soil interpretations.

The properties of soils occur along a continuum across most landscapes (Schoenenberger et al. 2002). The physical, chemical, and biological properties of soil, which include the organic and inorganic components, occur in gradations along hillslopes and throughout landscapes. The gradation of properties is due to the differential rate of weathering that takes place within a landscape (Johnson, 1963) in all types of parent material under varying climates and through time. Soil materials may be redistributed and differential rates of leaching may be observed as the weathering process continues to cycle. The result is due in large part by the movement of water both at the surface and below ground (Ruhe, 1975). Soil water is typically expressed as soil water content, stored soil water, or water that is in the process of being transported either at or below the soil surface. The constituent components of the minerals that make up various parent materials affect 
the rate of weathering (Buol and Eswaran, 2000), which in turn affect the soil genesis and morphology (Schaetzl and Anderson, 2005). Mineral weathering is enhanced in the presence of water. It is because of this that precipitation has been identified as one of the principal variables influencing soil formation (Jenny, 1941). Precipitation that falls on the land is partitioned into (i) runoff; (ii) infiltration and through flow; (iii) stored soil water; and (iv) evaporated water either at the surface or within the larger soil pores or transpired through the vegetation as evapotranspiration (Dingman, 2008). How that water is distributed into each of these components affects the rates of physical, chemical, and biological weathering of the soil. At the hillslope scale, this partitioning of water is strongly influenced by soil cover type and topography, as well as the properties of the soils (Lin et al., 2006).

The variation of soils that occur across a typical hillslope may in part be explained by the five soil forming factors (Jenny, 1941). The climate under which a soil develops plays a key role in the rate at which the diagnostic soil features develop as well as the extent of their expression. Biological activity (both plants and animals) under which the parent material is exposed contribute to the physical and chemical properties that result over time. While soil development may occur under any number of conditions, the observable features expressed in the soil profile reflect the history of the environment in which the soil has developed.

Hall (1983) has attributed water movement and distribution on the landscape as the primary reason for differences in soil development. Richardson et al. (1992) described the movement or restriction of movement of water as critical in the formation of soil. Soil morphology offers a long-term history of the conditions under which the soil has 
developed (Stolt et al., 1998). The determination of whether a soil is saturated at some time during the growing season can be interpreted from the soil morphology (Jacobs et al., 2002). Morgan and Stolt (2006), as a result of research linking redoximorphic features to seasonal high water table depths, suggest soil morphology be used when making land-use decisions. Additional research has contributed to the body of knowledge confirming a correlation between pedological development and the presence of water (Boersma et al., 1972; Simonson and Boersma, 1972; Vepraskas et al., 1974; Veneman et al., 1976;

Richardson et al., 1992; Thompson et al., 1998; Szogi and Hudnall, 1998; D’Amore et al., 2000; and references therein). As the soil is weathered and development occurs, recognizable features in the soil appear which provide the basis for soil classification (Soil Survey Staff, 1999), soil mapping, and development of interpretations.

\subsection{Soil Classification and Soil Survey}

The seasonal frequency and duration of soil saturation may be inferred from the taxonomic classification of a soil. Several soil classification systems exist in practice worldwide (Glazovskaya, 1972; Buol et al., 2003; and references therein). Each has been developed by soil scientists in particular countries or groups of countries to meet the need for the development of interpretations. The current U.S. classification system uses hierarchies of classes that take into consideration the relationships among and between soils and the factors responsible for their character. Soil Taxonomy (Soil Survey Staff, 1999) provides a means with which to classify soils to facilitate soil mapping and communicate information about soils through a soil survey. It assumes that the processes within the soil have been dominant for a long period of time. As a result of these processes, morphological and chemical characteristics of the soil are expressed (Schaetzl 
and Anderson, 2005). Through this taxonomic classification system, the pathways of soil development through which the soil forming processes have occurred, may be captured by grouping soils with similar properties into a single taxa. This is the genetic thread that links processes of soil development into groups of like soils. The soil taxonomic classification system is therefore properties-based. The categorically higher levels within this hierarchical system are based on the presence or absence of diagnostic surface and subsurface horizons. Once identified, these basic soil units may then be arranged in an orderly system. Through this system it is possible to establish interrelationships among and between the basic soil units (Beckmann, 1984). The concept of a soil series is that of a range of properties that collectively capture the interpretive uses of the soil as a whole and is the lowest level within the soil taxonomic classification system.

Delineated polygons on a soil map represent areas of similar soils grouped into soil map units (Soil Survey Division Staff, 1993). The purpose of these maps is to enable the assignment of interpretations of how the soil will respond under a wide range of uses and management regimes. Soil map unit delineations represent areas of soils dominated by properties that fit a range in characteristics of a named soil series and, to a lesser extent, other series that exhibit similar properties. Map units commonly contain inclusions of soils other than the named series for the particular map unit (Schaetzl and Anderson, 2005). This is due to the inherent variability of soil (Hole, 1978) at any scale of observation. Lin (2010) describes the irreversible nature of pedogenesis as evolving toward heterogeneity. The properties of the inclusions may be contrasting to those that determine the named series. The presence of such inclusions is necessary due to the scale of mapping and the complexity of the soils within most landscapes. A well designed soil 
map unit is one that is capable of capturing the full range of properties within a single polygon while maintaining usefulness for interpretation development. Extremely complex or overly simplified map units are of little value for the generation of interpretations. A balance of only the most pertinent information is the goal. The attribute data assigned to each polygon contain information of the properties of the soil. The reported information may be used for the development of interpretations for each soil or for individual components of a map unit. This properties-based development of interpretations allows the analyst to make informed decisions regarding the management and predictability of the soil response to a variety of uses. Soil map unit delineations are cartographic representations of recurring predictable patterns of soils which are fundamental to the development of a soil map.

A fragipan or lithic contact greatly influences interpretations; other diagnostic horizons such as albic or cambic has little influence on interpretations. The ability to recognize diagnostic features while in the field is fundamental to soil mapping. Further, recognizing the repeating pattern of associated soils that occur on any given landscape is the ongoing challenge facing soil scientists (Gerrard, 1993). The goal is to provide the user of soils information with the most robust set of data with which to predict soil behavior under the widest range of potential uses as possible.

\subsection{Fragipans}

A fragipan is a subsurface horizon that restricts the entry of water and roots into the soil matrix. The properties of the fragipan effect root growth as well as the water regime of the soil. The restriction of roots and water into the soil matrix is due to the high bulk density relative to the horizon above the fragipan. The orientation and close-packing of the 
soil particles within the fragipan restricts root growth and limits water movement, thereby creating seasonally saturated conditions above the fragipan (Ciolkosz and Waltman, 2000). Consequently, fragipan layers often have evidence of saturation just above the contact with the top of the diagnostic horizon (Norfleet, 1992). Individual peds within the fragipan exhibit a polygonal pattern when observed in the horizontal cross-section, allowing some water and root penetration into the cracks between the polygonal faces. Dabney and Selim (1987) found penetrometer resistance in the ped interiors to be greater than the resistance between the peds. Characteristically, fragipan soils are often overlain to the top of the fragipan zone with colluvium or re-worked eolian deposits, usually high in silt content, of appreciable depth (usually less than $1 \mathrm{~m}$ ) (Drohan et al., 2009). The loosely packed overlying deposits allow for the relatively high percolation of water necessary to translocate weathered mineral by-products from higher in the soil profile to lower in the solum at the contact with the fragipan. Because of the dense properties of the horizon and the relatively thin soil above the pan, the water table levels may be near the soil surface many times throughout the growing season (McDaniel et al., 2001). Day et al. (1998) determined that $63 \%$ of the water on a hillslope in northeastern Pennsylvania moved laterally off slope at the contact with the fragipan. Their results also show that of the remaining $37 \%$ that moved through the fragipan, approximately $10 \%$ moved laterally and $27 \%$ moved vertically through the interconnected prism faces. In a study by McDaniel et al. (2007), subsurface lateral flow at the contact with the fragipan was $90 \%$ of the measured precipitation and snowmelt in early spring.

Soil horizons that meet the following criteria and have an upper boundary within 1 m of the soil surface are considered fragipans as defined by the Soil Survey Staff (2010). 
The horizon must meet the minimum thickness requirement of at least $15 \mathrm{~cm}$. There must be evidence of pedogenesis in addition to density and brittleness within the horizon. Roots and water must be restricted from 60 percent or more of the volume of the horizon. Soil aggregates between 5 to $10 \mathrm{~cm}$ diameter from more than 50 percent of the horizon must slake (disperse and break apart) when submerged in water, and the soil must not effervesce in dilute $\mathrm{HCl}$.

The genesis of fragipans is obscure (Grossman and Carlisle, 1969), but fragipans are considered pedogenic soil horizons. Most fragipan soils exhibit the presence of oriented clays (either in the matrix or on the faces of peds), albic materials or coatings of albic materials on faces of peds or between the ped faces, soil structure, and redoximorphic features in the matrix or on faces of peds (Soil Survey Staff, 1999). Illuviation is likely the cause of redistribution of clay and other weatherable minerals downward into the underlying horizons and may be the cause of the start of fragipan development as suggested by Norfleet (1992).

Many papers have been published in which the research focus has been on the processes and mechanisms behind the development of a fragipan (Grossman and Carlisle, 1969; Bryant, 1989; Norfleet, 1992; Payton, 1992; Duncan and Franzmeier, 1999;

Ciolkosz and Waltman, 2000; Scalenghe et al., 2004; Weisenborn and Schaetzl, 2005; and references therein). The genesis of fragipans has been considered by some a subject of controversy (Karathanasis, 1987), and is beyond the scope of this manuscript. More important to the topic of this paper is prior research that has addressed the role of the fragipan on perching water on hillslopes. Miller et al. (1971) studied precipitation and the subsurface lateral flow above fragipans in Eastern Ohio. Miller et al. (1971) determined 
that water flows across fragipan surfaces. Heald and Rogowski (1977) examined the use of chemical analysis of water samples to complement hydrologic data in east-central Pennsylvania. They described "mounds" (perching water) due to physical barriers in their “sloping fragipan system.” Dabney and Selim (1987) analyzed fragipan soil cores to determine lateral and vertical flow above and through the fragipan. Parlange et al. (1989) investigated the water distribution at the contact with the fragipan zone in New York and concluded that the average distance between the cracks of the fragipan polygons are linked to the subsurface flow of water above the fragipan. Rhoton and Romkens (1998) analyzed plant available water of the fragipan zone in Mississippi and determined that roots have "indirect" access to water within the restrictive zone. They determined that fragipan horizons contributed water to the horizons above during the growing season. McDaniel et al. (2001) researched seasonally perched water tables in the northwest U.S. and concluded that perching varies considerably from year to year. McDaniel et al. (2007) scrutinized the link between fragipans, perched water tables, and hydrologic processes in the northwest U.S. and described the "flashy" response of perching to storm events. Gburek et al. (2006) observed fragipan soils of east-central Pennsylvania and noted that these soils can dominate runoff response after a storm event. Gburek et al. (2006) describe a nexus between soils mapped as having fragic properties and the ability to understand the hydrology at a watershed scale. Gburek et al. (2006) results show that fragipan soils produce runoff an order of magnitude greater than similar non-fragipan soils.

Related research on non-fragipan soils has shown that water movement is not only restricted to the vertical forces of gravity but is likewise influenced by property discontinuities in horizons that favor lateral subsurface flow. In Mollisol soils in 
Minnesota, Thompson et al. (1998) found lateral groundwater flow which they attributed to the stratigraphy of the parent material. Similar results were determined by D'Amore et al. (2000) in western Oregon, in which a link between piezometer derived water levels and soil stratigraphy was made. Lacking in the literature, however, is a conceptualization of the role that fragipan soils contribute to the mid-Atlantic hillslope hydrology, particularly on the heavily forested hillslopes of West Virginia. This is in spite of the relatively large area - estimated at 2 million ha ( $~ 5$ million ac) - associated with fragipan soils in the region given the hydrological importance that these soils have on the total landscape.

\subsection{Linking Pedology and Hydrology into a Hydropedological Approach}

Pedology has been defined as a unique branch of soil science whereby the morphology, classification, and distribution of soils are quantified and integrated at the landscape scale (Wilding, 2000; Buol et al., 2001; Lin et al., 2006; and references therein). The properties of soils on most hillslopes exhibit spatial variability due to differential weathering driven by flow and transport in the vadose zone (Wilding and Lin, 2006). Water movement through the soil is dynamic and complex. This phenomenon is compounded at the watershed scale. The behavior of water movement attributed to stratigraphically or pedologically variable zones in the soil is of particular interest to many users of the soil resource.

Hydrology is the science that is concerned with the origin, circulation, and distribution of water around the globe (Dingman, 2008). It encompasses all phases of water and at all scales (point, local, regional, and global). The spatial and temporal variation of water as it occurs in the soil is of interest to many. The discontinuity of soil properties within a hillslope due to inherent soil heterogeneity often leads to complex 
hydrologic processes (Corwin et al., 2006). Some understanding of these processes can be accomplished by coupling the observation of soil morphological features with known hydrologic events through continuous monitoring of hillslope soil hydrology (Lin et al., 2006). This is the hydropedological approach and is the field of study that interlocks the disciplines of hydrology and pedology (Lin, 2003) into a single research approach. Understanding the association between the two disciplines will aid in more complete and accurate set of soil interpretations at a multitude of scales.

In the mid-Atlantic region of the U.S., fragipan soils make up a large geographical extent of the landscape. It is estimated from the current Soil Survey Geographical (SSURGO) database that soils with fragipan properties occupy 40 percent of the land area within the Appalachian Plateau's physiographic province (Sharon Waltman, personal communication, 2009). Pedologically, the presence of redoximorphic features leads to the expectation that water is perching for a significant period of time during the growing season. The relationship between hillslope position and soil wetness is examined by comparing the depth of water perching at the contact with the fragipan layer at multiple hillslope locations across the upper reach of a representative watershed. The piezometric head at the fragipan contact as well as deeper in the soil profile are examined.

The strategic placement of hydrologic monitoring instrumentation on a benchmark soilscape is critical toward providing the users of soil information with research-based predictions of water movement at the soil-water interface. Hydropedologically linked characteristics have been identified as an area that is in critical need of further exploration (Lin et al., 2006). Understanding the processes at the field instrument level is the first step toward the spatial aggregation and prediction of soil/water interactions at the hillslope, 
catchment, watershed, river basin, and global scale. Collecting in situ hydrologic data in a manner designed to develop a concept model is an effective means of addressing the multiscale need hydropedological information. Thompson et al. (1998), in reference to the links between wetland hydrology and soil genesis at a hillslope scale, suggested that the temporal dimension be included in modeling of those processes. Through the inclusion of the temporal component of these studies, mapping tools in the form of conceptual hydropedological models may be developed.

\subsection{Objectives}

The objective of this research was to select a representative hillslope of fragipan dominated soils common in West Virginia, at which strategically placed in situ hydrologic point measurements could be taken. The purpose driving the collection of the data was to facilitate the development of a concept model not only capable of predicting the temporal and spatial presence of water at the study location, but to enable the inference to noninstrumented locations throughout the region. To facilitate the development of this concept model, research hypotheses were developed and tested.

\subsection{Hypotheses}

There are seven hypotheses for which this field research has been designed to address. The first of which involves the relationship between soils with fragipan properties and the movement of water within the soil profile. McDaniel and Falen (1994) described significant perching of water above the fragipan (episaturation). Karathanasis et al. (2003) determined fragipans have an effect on episaturation. McDaniel et al. (2008) linked fragipan soils with perched water tables. Calmon and Day (1999) established that 
fragipans with low $\mathrm{K}_{\mathrm{sat}}$ relative to layers above tend to perch water. Heald and Rogowski (1977) reported perched water tables above the fragipan horizon to be greatest after storm events. The specific research hypothesis is: The fragipan will restrict the downward movement of water $\left(H_{1}\right)$.

The second hypothesis is related to hillslope position and the amount of saturation of the fragipan soils at each position. Karathanasis et al. (2003) described the longest saturated conditions at the lowest positions on the landscape. Calmon and Day (1999) established a significant effect of landscape position on fluctuating water tables, reporting that the footslope positions have the highest number of days of saturation, followed by the summit position, while the backslope position had the fewest. The specific research hypothesis is: The footslope position will be the wettest location on the hillslope $\left(\mathrm{H}_{2}\right)$.

The third and fourth research hypotheses compare the fragipan soil and the nonfragipan soil found on site, with their respective thickness and duration of perched water, as well as their flashy response to storm events. Lindbo et al. (1995), while comparing fragipan soils with non-fragipan soils described less brittleness and greater root penetration in the non-fragipan soils (which leads to the expectation of greater water movement due to the presumption of lower bulk density in the non-fragipan soil). McDaniel et al. (2008) found fragipan soils with high $\mathrm{K}_{\mathrm{sat}}$ surface layers to be hydrologically very flashy. The rate at which water moves through each of the soil horizons is a key component to understanding the potential for water movement within the watershed hillslope. Water moves through soil most rapidly when the soil is under saturated conditions. When soil is at saturation (all pores become filled with water) gravity becomes the dominant influence on water movement. The specific research hypotheses are: Fragipan soils will perch less 
water and for shorter duration than the paralithic contact soil $\left(H_{3}\right)$; and fragipan soils will react faster to storm events (i.e., more flashy) than the paralithic contact soil $\left(\mathrm{H}_{4}\right)$.

The fifth research hypothesis involves the relationship between the thickness of water and slope aspect. Carter and Ciolkosz (1991) described soil development differences due to north-south aspect differences and attributed these differences to higher moisture levels on the northwest facing slopes when compared to the southwest facing. Reid (1973) deduced cumulative differences in evaporative water loss between north-facing and southfacing slopes to be small but further stated that over time the small differences may have an effect on the long-term hydrologic balance. They described groundwater seeps and springs as more prevalent on the north-facing aspect. The specific research hypothesis is: The thickness of water will be greater on north-facing slopes $\left(H_{5}\right)$.

The sixth research hypothesis is related to the relationship between the thickness of water perching and season. McDaniel and Falen (1994) showed the influence of fragipans on perching water to be proportionally higher during low potential evaporation periods. Karathanasis et al. (2003) described water tables nearer the surface in late winter and spring. Calmon and Day (1999) found fragipan related water tables to be absent during summer. McDaniel et al. (2008) linked fragipan soils to the development of seasonal perched water tables. The specific research hypothesis is: The thickness of water perching will be greater during the winter $\left(H_{6}\right)$.

The seventh research hypothesis involves the thickness of water perching on top of the fragipan and slope curvature. Calmon and Day (1999) established that fragipans on backslopes, experience greater short-duration saturation events than on shoulder slopes. Famiglietti et al. (1998) reported that once the surface layer was moistened during a storm 
event and allowed to dry, that a correlation between curvature and percent soil moisture content became apparent. Further concluding that lateral movement was more strongly correlated to profile curvature than to plan curvature. Fujimoto et al. (2011) scrutinized the effect of planar versus convergent hillslope types on water movement during varying rainfall events. These authors concluded that during low precipitation events, planar slopes continue to contribute to runoff while convergent areas retained the water on the hillslope longer. The hillslope position of backslope contains three unique slope curvatures in the plan view: linear, concave, and convex. As such, it is expected that the thickness of water perching on top of the fragipan will vary across the backslope related to slope curvature. The specific research hypothesis is: The concave position will exhibit the greatest thickness of water perching followed by the linear with the convex exhibiting the least thickness of water perching $\left(H_{7}\right)$. 


\section{Materials and methods}

\subsection{Geographical Area}

This research was conducted in Major Land Resource Area (MLRA) 127 (Eastern

Allegheny Plateau and Mountains). This MLRA comprises 50,370 km² (5,037,000 ha) and occurs in Maryland, New York, Pennsylvania, Virginia, and West Virginia (Figure 2-1). The physiographic area is a deeply dissected plateau with the high escarpment of the Allegheny Front forming the eastern boundary of the MLRA where it borders the Northern Appalachian Ridges and Valleys (US Department of Agriculture, 2006). The elevation range within the plateau is typically $300 \mathrm{~m}$ to $800 \mathrm{~m}$ with local relief of about $100 \mathrm{~m}$. The elevation of the summits in the mountain portion of the MLRA in the southeastern part of the region ranges from $1,100 \mathrm{~m}$ to over $1,400 \mathrm{~m}$. The geology consists of alternating beds of sandstone, limestone, coal, and shale in the uplands, and the major river valleys are filled with unconsolidated alluvial deposits of sand, silt, clay, and gravel. The lower portion of most hillslopes is mantled with varying thicknesses of colluvial deposits. 


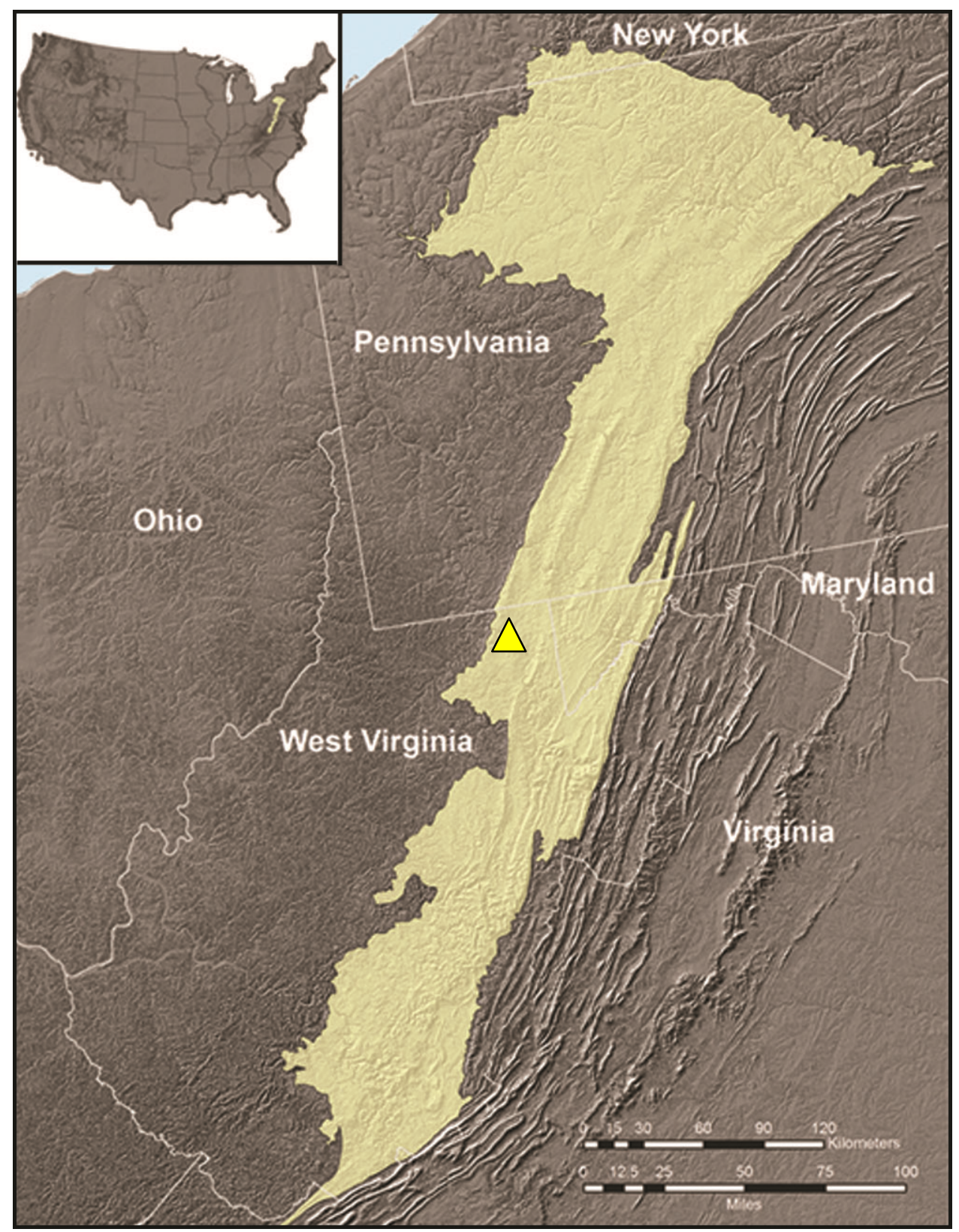

Figure 2-1: Geographic extent of MLRA 127 in the continental U.S. The location of the study area is indicated by the yellow triangle.

The average annual precipitation of the entire MLRA ranges from 840 to $1,725 \mathrm{~mm}$

(33 to 68 inches). The average annual temperature ranges from 6 to $12{ }^{\circ} \mathrm{C}$ (43 to $\left.54{ }^{\circ} \mathrm{F}\right)$.

The frost-free period ranges from 115 to 205 days with an average of 160 days (US

Department of Agriculture, 2006). Soils of MLRA 127 are dominated by Ultisols and 
Inceptisols. The soils occur dominantly in the mesic soil temperature regime with some having developed under frigid temperature regimes occurring in the northern part of the area and at higher elevations. The soils throughout the MLRA developed under udic soil moisture regimes and have mixed or siliceous mineralogy. These soils are generally moderately deep to very deep, excessively to somewhat poorly drained. Soils with fragic properties typically formed in the colluvium on backslope and footslope positions. Other Ultisols and Inceptisols formed in residuum on hills and ridges. A smaller extent of Entisols can be found throughout the area, usually associated with surface mining activities. The soils of this physiographic region provide a medium for high-quality hardwood growth with species such as oak, black cherry, yellow-poplar, maple, and other associated hardwoods common. Most of MLRA 127 is forested (76\%), followed by cropland (7\%), pastureland (7\%), urban development (6\%), water $(1 \%)$, and other uses (3\%). The main forest management concern throughout the MLRA is the proper construction of forest harvest trails, critical area planting, and water bars on trails (US Department of Agriculture, 2006).

\subsection{Site Description}

The research site is located approximately $15 \mathrm{~km}(\sim 9 \mathrm{mi})$ east of Morgantown, West Virginia (Fig. 2-2) in Coopers Rock State Forest. The study area consists of a 53 ha catchment (Fig. 2-3) located in north-central West Virginia. The geology at the site is largely comprised of Pottsville Formation bedrock (Hare, 1957), which is dominated by strongly cemented sandstone (upper and lower Connoquenessing sandstones) overlain by the Mercer Shale of varying thickness and capped with the Homewood Sandstone. 
Cardwell et al. (1975), maps the lowest portion of the research watershed as Mauch Chunk Formation.

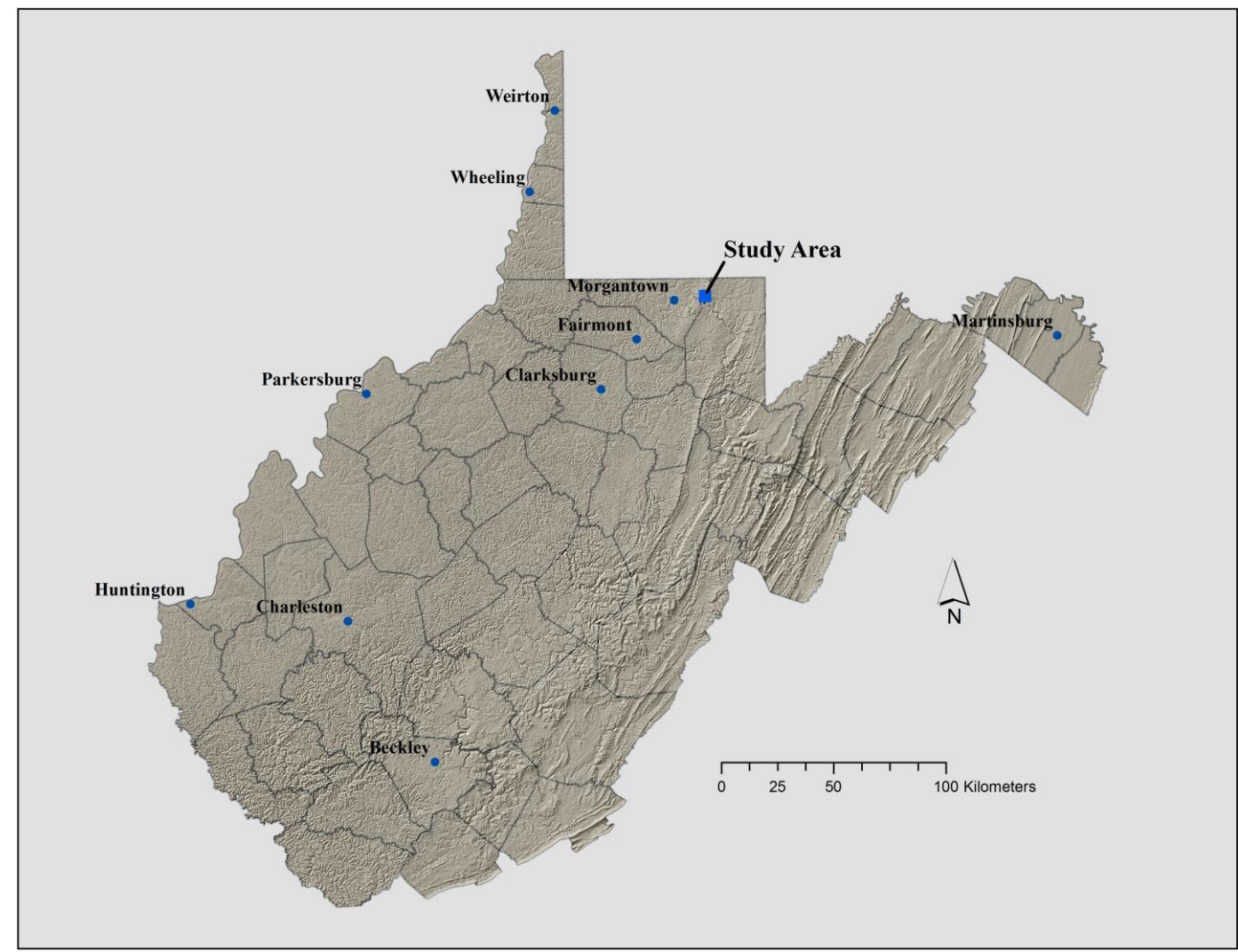

Figure 2-2: The study area is located in north-central West Virginia approximately $15 \mathrm{~km}(\sim 9$ mi) east of Morgantown.

\subsection{Soil Characterization}

The soils at the site of this research developed in the colluvium and to a lesser extent residuum associated with the alternating beds of sandstone and shale. The dominant soils within this watershed are benchmark soil series. Benchmark soils are soils of a series or multiple series (i) that are of large extent, (ii) that hold a key position in the soil classification system, (iii) for which there is a large amount of data, or (iv) that have special significance to farming, engineering, forestry, ranching, recreational development, urban development, wetland restoration, or other uses (USDA, 2007). Benchmark soils are 
selected based on the greatest potential for the extrapolation of key properties and, most importantly, the interpretations of those properties, to other soils. There is a relatively high cost associated with performing on-site soil investigations and research (Calmon and Day, 1999) and therefore benchmark soils are targeted for research and the information gleaned from those studies is extrapolated to other like regions.

A soilscape is a geographically recognizable unit along a soil continuum (Hole, 1978). Soilscapes contain a limited number of soils grouped by properties that are distributed in a geographically identifiable pattern (Lagacherie et al., 2001). To assure the most efficient use of limited resources, soilscapes that consists of benchmark soils are targeted. A study site that satisfies the benchmark soilscape criteria as defined above was selected for this research. The soils map (Soil Survey Staff, 2008) of the study area includes the benchmark soil series (Soil Survey Staff, 2008) of the Buchanan series and the Tilsit series (Figure 2-3). Upon field review of the soil map, it was determined that the Dekalb soil series was over-mapped. The DdE map unit (Figure 2-3) consists mostly of soils with fragipan horizons, which is not consistent with the Dekalb soil series concept. 


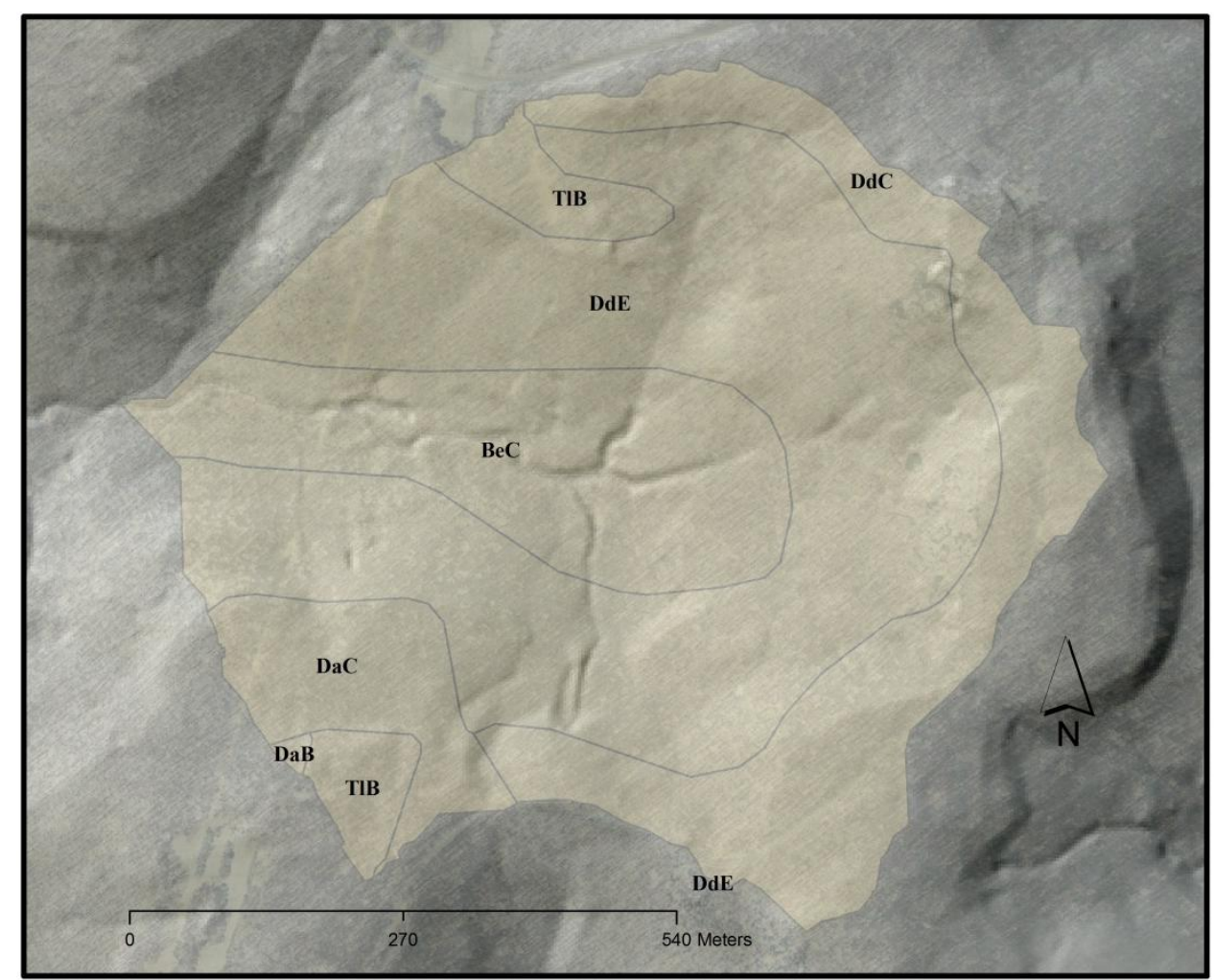

Figure 2-3: The study area consists of a 53 ha (131 ac) catchment. The soils map (Soil Survey Staff, 2008) of the study area includes the benchmark soil series of Buchanan and Tilsit (BeC and TIB respectively). Also mapped is the Dekalb soil series (DaB, DaC, DdC, and DdE).

Field work started in the early winter of 2008. A preliminary soils investigation was performed by transecting the hillslopes and writing soil profile descriptions focusing the location of the independent observation at each hillslope position change. Detailed soil profile descriptions were taken at the hillslope summit, shoulder, backslope, footslope, and toeslope positions using standard procedures as described by Schoeneberger et al. (2002). During the initial phase of research, approximately twenty detailed soil profiles were described throughout the entire study area and the following data was recorded: (1) the location of the observation with respect to the position on the landform, hillslope position, slope aspect, and slope gradient; (2) the depth to redoximorphic features (both depletions and concentrations); (3) the depth to the top of and the thickness of the fragipan, if present, 
or the argillic horizon if no pan was present; and (4) the makeup of the underlying stratigraphy (if observed within $2 \mathrm{~m}$ depth). Upon review of the initial soil profile descriptions, six point locations on the hillslope were selected for further study. These selected sites were paired observations on both the north-facing and south-facing slope at the summit, backslope and footslope hillslope position (Figure 2.5). Labels of the paired sets that will be used throughout this dissertation were derived from a combination of hillslope position followed by the slope aspect on which the point is located. I will use Summit (south), Backslope (south), Footslope (south), Footslope (north), Backslope (north), and Summit (north) to identify the site under discussion. When discussing observations made at depth within the soil, a descriptive depth modifier, e.g., Summit (south, shallow), Summit (south, deep), etc. will be used.

\subsubsection{Soil Characterization Sampling}

Six soil pits were excavated, described, and sampled to characterize the soil within the watershed. To eliminate potential negative effects caused by the use of heavy machinery, only hand equipment was used. Hand-dug rectangular soil pits approximately $1.5 \mathrm{~m} \times 2 \mathrm{~m}$ were opened to a depth of $1.75 \mathrm{~m}$. Pits along a north-south transect were located at the Summit (south), Backslope (south), Footslope (south), Footslope (north), Backslope (north), and Summit (north). Detailed soil profile descriptions were prepared using standard procedures as described by Schoeneberger et al. (2002), on the up-gradient pit wall at each of the six site locations. The observed horizons at each pit location were then sampled following National Soil Survey Laboratory procedures (Soil Survey Laboratory Staff, 2004). While collecting the soil samples special care was taken to 
minimize the disturbance to the freshly exposed up-gradient pit wall. To facilitate this, samples were extracted from the exposed wall perpendicular to the up-gradient pit face. Sampling occurred in early July 2009. The samples were sent to the National Soil Survey Lab (NSSL) in Lincoln, Nebraska, for complete characterization analysis. Analyses performed include: particle size distribution analysis (PSDA) and rock fragments; bulk density and moisture; carbon and extractions; cation exchange capacity (CEC) and bases; pH; organic; and clay mineralogy (Soil Survey Laboratory Staff, 2004).

\subsection{Hydrologic Monitoring}

While the soil pits were open for the soil characterization sampling, probes specifically designed for soil moisture monitoring were installed in the upslope sidewall of each pit. The upslope side was chosen to minimize the impact of the disturbance caused by the opening of the access pit. By installing the instruments in this manner, water moving down slope will first encounter the probes/sensors before entering the disturbed area. This is the currently accepted method of installation of the devices chosen for this research (personal communication, Lin, 2008).

All probes were installed in a vertical point of reference, perpendicular to the orientation of the horizon within the soil profile (Decagon Devices, Inc., 2008). In each pit a total of nine soil moisture sensing probes capable of taking a total of 21 measurements were inserted in select horizons. Sensor type, horizon name and respective depth of installation were recorded. A small tipping-bucket rain gauge was also affixed at the top of a metal fence post (about $1.5 \mathrm{~m}$ above ground elevation) installed at each site. All sensors and gauges were linked by cables to two separate data logging devices attached below the rain gauge on the metal posts. Once installation was complete at all six locations, the data 
loggers were set to query the sensors at 10 minute intervals. Figure 2-4 shows the probe and sensor installation depths of one of the six instrumented hillslope locations. (See Appendix for the schema of the installed probes at all six locations).

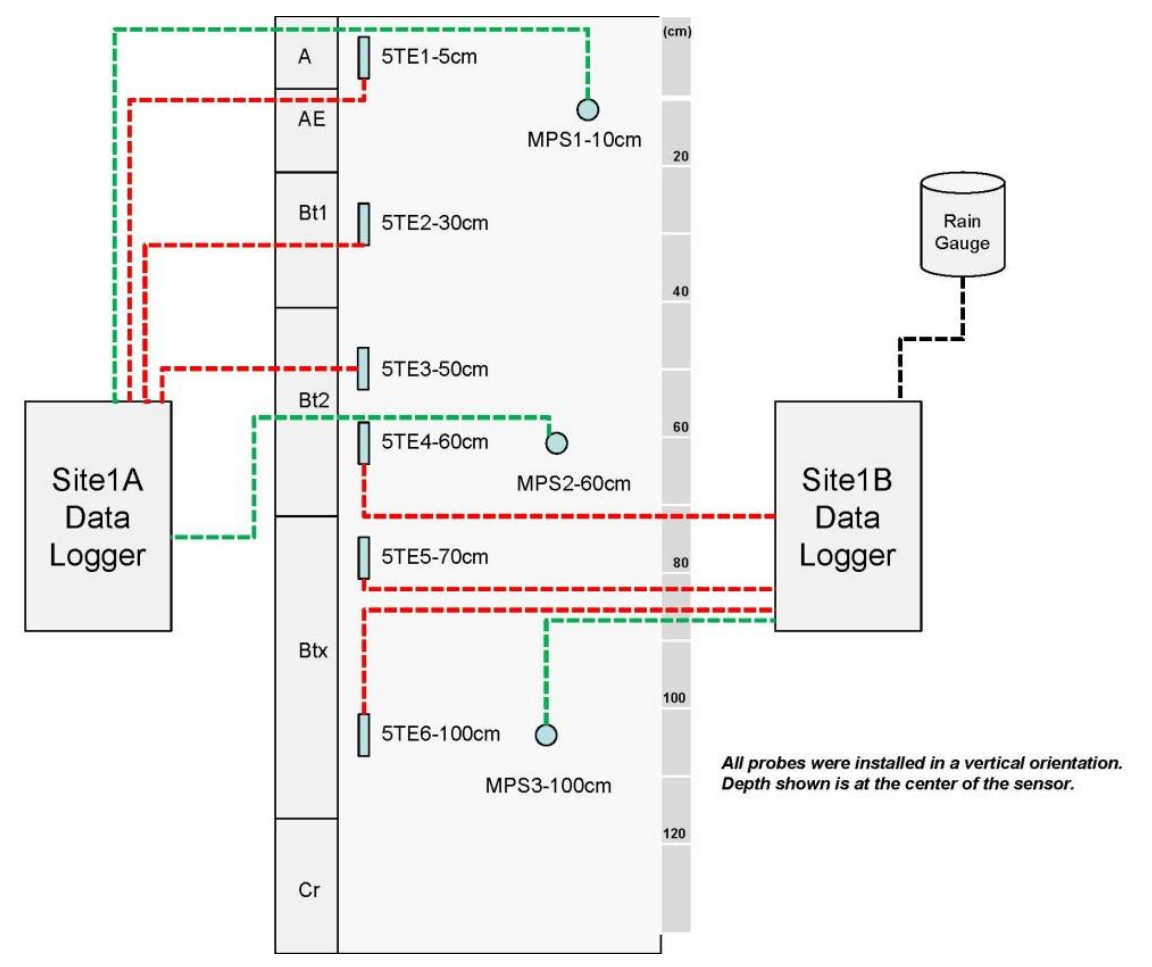

Figure 2-4: Schema of the hydrologic monitoring probes installed at the Summit (south) location.

\subsubsection{Volumetric Water Content and Soil Temperature}

Decagon ${ }^{\circledR} 5$ TE probes were installed at select horizons to measure the volumetric water content $\left(\mathrm{m}^{3} \mathrm{~m}^{-3}\right)$ and soil temperature $\left({ }^{\circ} \mathrm{C}\right)$. The compact 5 TE probe is a good choice for installation at this site as it is designed as a single unit with the capability of performing multiple property measurements. In situ soil measurements have the potential to be less reliable due to the disturbance required during installation of sensors. Every effort was made during the installation of the probes to minimize the soil disturbance driven by the 
goal of collecting the most accurate measurements of in situ properties at the soil-water interface as possible.

The volumetric water content $\left(\mathrm{m}^{3} \mathrm{~m}^{-3}\right)$ is interpreted from the stored electrical charge in each horizon. The Decagon ${ }^{\circledR} 5$ TE probes utilize an electromagnetic field to measure the dielectric permittivity of the soil material surrounding the probe. When queried, the probe supplies an oscillating wave that charges according to the dielectric of the soil material in which the probe is installed. The measured (stored) charge is proportional to the soil dielectric, which is related to the soil volumetric water content. The 5TE unit has a microprocessor that measures the charge and outputs a value of dielectric permittivity from the probe. Typical soil material has a dielectric of less than 5 while water has a dielectric of nearly 80 . The higher the dielectric constant the more water is in the soil surrounding the probe. In this manner, the volume of water present per unit volume of soil immediately surrounding the probe may be recorded.

Soil temperature $\left({ }^{\circ} \mathrm{C}\right)$ measurements were taken at multiple depths using a surfacemounted thermistor that is built into each of the 5TE probes.

\subsubsection{Piezometric Head}

The piezometric head is the amount of pressure exerted at zones within the soil that is directly related to the column of water found at the location. Height of water column may be utilized to compare the effect of soil properties at multiple depths within a soil profile. Additionally, comparisons at multiple hillslope position locations enhance our understanding of saturated flow throughout a watershed. A pair of nested piezometers, one at the fragipan contact and one lower in the profile, was installed at the six major hillslope position locations described above (Figure 2-5). Table 2-1 depicts the depth and 
associated horizon of the installed nested-piezometers by hillslope location. Two additional sites were instrumented at the backslope position to compare the effect of slope curvature (of the backslope) on water table depth (locations are not depicted in the Figure 2-5).

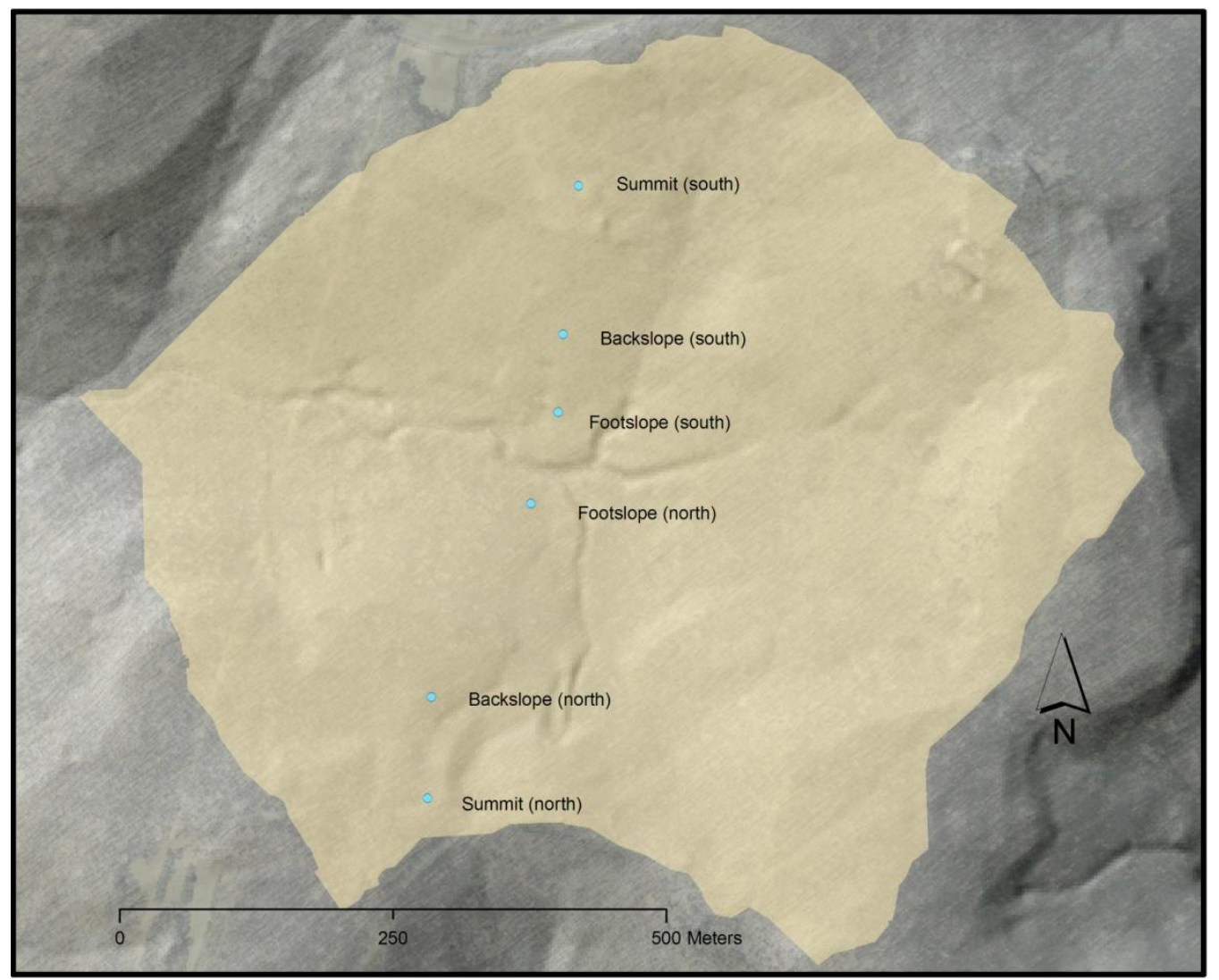

Figure 2-5: Each aspect-paired hillslope position was instrumented with a set of nested piezometers 
Table 2-1: Horizon and depth of installed nested-piezometers by hillslope position.

\begin{tabular}{lllllc}
\hline \multirow{2}{*}{ Site } & \multicolumn{2}{c}{ Shallow piezometer } & & \multicolumn{2}{c}{ Deep piezometer } \\
\cline { 3 - 3 } \cline { 5 - 6 } & Horizon & Depth & & Horizon & Depth \\
\hline Summit (south) & & $\mathrm{cm}$ & & $\mathrm{cm}$ \\
Backslope (south) & $\mathrm{Btx} 1$ & 57 & & $\mathrm{Cr}$ & 158 \\
Footslope (south) & $\mathrm{Btx} 2$ & 74 & & $\mathrm{Cr}$ & 141 \\
Footslope (north) & $\mathrm{Btx} 1$ & 79 & & $\mathrm{Btx} 3$ & 152 \\
Backslope (north) & $\mathrm{Btx} 1$ & 69 & & $\mathrm{Btx} 3$ & 150 \\
Summit (north) & $\mathrm{Cr}$ & 52 & & $\mathrm{Btx} 3$ & 118 \\
\hline
\end{tabular}

At the time of installation of the access PVC tubes, additional soil profile descriptions were taken to assure accuracy of the placement of the instrumentation. To facilitate the installation of the piezometric head pressure transducers, holes $(7.62 \mathrm{~cm} \mathrm{dia.})$ were opened to the depth of the top of the fragipan horizon. The fragipan horizon in the soil is immediately below an overlying argillic horizon and is near the contact where the redoximorphic features of the overlying argillic horizon begin to increase from few $(<2 \%$ of area of ped face) to common (2-20\% of area of ped face). The bore hole was extended into the fragipan layer to a depth of approximately $5 \mathrm{~cm}$. PVC pipes were installed following the standard procedure identified for installing equipment for the hydric soil technical standard (Sprecher, 2008). The slotted portion of the PVC was surrounded with $>0.3 \mathrm{~mm}$ dia. sand until the slotted portion of the pipe met with the solid. At the solid portion of the pipe bentonite clay was packed around the PVC to assure a close fit with the pipe to restrict downward movement of water from above the zone of interest. A second PVC tube was installed approximate $1.5 \mathrm{~m}$ away from the previously installed piezometer at a depth below the fragipan or $>150 \mathrm{~cm}$ if still in the horizon with fragipan characteristics.

Solinst ${ }^{\circledR}$ pressure transducers with built-in data loggers were inserted into the PVC access tubes and initially launched to record the depth of water at each nested location at 6 
hour intervals. The measurement time was changed to record every 10 minutes early in the first season to capture the storm-event effect as described by McDaniel et al. (2007) as "very flashy". An observation well (completely slotted PVC) was installed near the outlet of the watershed to measure the streamflow.

\subsection{Precipitation}

Thirty-year daily temperature and precipitation data is available from the Cooper's Rock State Forest Weather Station (CRSF-WS) located within the West Virginia University Forest $3 \mathrm{~km}(1.9 \mathrm{mi})$ northeast of the watershed. A summary of long-term weather data at the West Virginia University Forest is provided by Carvell (1983).

Previous research has shown that spatial variation of throughfall contributes to the variation in soil moisture patterns (Keim et al., 2006). Consequently, rain gauges were installed at each of the six selected locations along the north-south transect of the hillslope. The gauges are subjected to the interception of rainfall due to the fully forested canopy found at the site. Ford and Vose (2007) have linked canopy interception with soil moisture. The precipitation gauges were set to record rainfall at the 10 min time-step.

\subsection{Saturated Hydraulic Conductivity $\left(K_{\text {sat }}\right)$}

Saturated hydraulic conductivity $\left(\mathrm{K}_{\mathrm{sat}}\right)$ measurements were taken in select horizons in situ using compact constant head permeameters (CCHP) (Amoozegar, 1989).

Measurements were taken at each of the six hillslope positions. The CCHP measurements were taken in three replications in each of the major horizons identified. Horizons measured include the near surface; the argillic; the fragipan; and the paralithic material. The placement of each measurement was within $3 \mathrm{~m}$ of the instrumentation at each hillslope site. 


\subsection{Streamflow}

In August 2009 a well was installed at a stable portion of the stream bank near the watershed outlet. The well placed in the stream bottom, is a slotted PVC access tube with a pressure transducer inserted to measure the stage height of the water in the stream. The logger was set to record at 10 minute time-steps.

A stream cross-section varies from one side of the stream bank to the opposite side of the stream. Likewise, depth of water will vary depending on the location along the cross-section at which the measurement is taken. To determine the volume flow rate of streamflow near the outlet of the watershed, salt-tracer experiments were conducted during the low and high streamflow period following Moore (2005). A known mass of sodium

chloride was injected into the stream and volume flow rate $\left(\mathrm{L} \mathrm{s}^{-1}\right)$ was calculated using the time difference between the first detection and return to pre-detection levels at a downstream electrical conductivity (EC) sensor. 


\section{Results and Discussion}

\subsection{Soil Characterization Sampling}

Select results of the lab analyses as well as select properties as described in the soil pedon descriptions are shown in Table 3-1. Complete results of the laboratory analyses may be found in the appendix (6.1. NSSL Results). An identification code is provided below the column header that references the laboratory methods used for each analysis. Refer to Soil Survey Laboratory Staff (2004) for the detailed procedures. Complete soil profile descriptions are also provided in the appendix (6.4. Pedon Descriptions).

An appreciable amount of leaf litter was described on the surface at all site locations. Oi horizons that are $3 \mathrm{~cm}$ thick and consist of undecomposed leaf litter were described at all locations with the exception of Summit (north) where the layer is $6 \mathrm{~cm}$ thick. The relatively thick organic layer at the surface may provide insulation to the underlying mineral horizons. (See section 3.6 and associated tables for discussion of soil temperature results.) Soils with fragic properties, designated as Btx horizons, were described at all site locations with the exception of the Summit (north). At the Summit (north) a paralithic contact, designated as Cr was described. At the Summit (south) and the Backslope (south) a paralithic contact was described below the fragipan (102 cm and 117 cm, respectively). At the Footslope (south), Footslope (north), and Backslope (north) locations, the depth of observation terminated while still in a fragipan horizon $(150 \mathrm{~cm})$. 
Table 3-1: Selected properties of the soils by hillslope location.

\begin{tabular}{|c|c|c|c|c|c|c|}
\hline Horizon & Depth & Texture & $\begin{array}{l}\text { Bulk } \\
\text { density }\end{array}$ & $\begin{array}{l}\text { Redoximorphic } \\
\text { features type }\end{array}$ & $\begin{array}{c}\text { Total } \\
\text { porosity }\end{array}$ & $\mathrm{K}_{\text {sat }}$ \\
\hline \multirow{2}{*}{\multicolumn{6}{|c|}{$\begin{array}{l}\mathrm{cm} \\
\quad \text { Summit south }\left(39^{\circ} 39^{\prime} 6.50^{\prime \prime} \mathrm{N}, 79^{\circ} 47^{\prime} 23.10^{\prime \prime} \mathrm{W} \text { : elevation } 666.7 \mathrm{~m}\right)\end{array}$}} & $\mathrm{cm} \mathrm{h}^{-1}$ \\
\hline & & & & & & \\
\hline Oi & $0-3$ & leaf litter & 0.10 & --- & 0.92 & --- \\
\hline A & $3-7$ & sil & 0.64 & --- & 0.76 & 20.7 \\
\hline $\mathrm{AE}$ & $7-15$ & sicl & 1.34 & --- & 0.49 & 20.7 \\
\hline Bt1 & $15-47$ & sicl & 1.60 & --- & 0.40 & 0.01 \\
\hline Bt2 & $47-66$ & sicl & 1.67 & masses and depletions & 0.37 & 0.01 \\
\hline Btx & $66-102$ & sil & 1.93 & masses and depletions & 0.27 & 0.01 \\
\hline $\mathrm{Cr}$ & $102-150+$ & ( sil) & 1.94 & --- & 0.27 & -- \\
\hline \multicolumn{7}{|c|}{ Backslope south $\left(39^{\circ} 39^{\prime} 1.60^{\prime \prime} \mathrm{N}, 79^{\circ} 47^{\prime} 23.20^{\prime \prime} \mathrm{W}\right.$; elevation $\left.643.6 \mathrm{~m}\right)$} \\
\hline $\mathrm{Oi}$ & $0-3$ & leaf litter & 0.04 & --- & 0.97 & -- \\
\hline $\mathrm{Oe}$ & $3-6$ & mkpt & 0.07 & --- & 0.95 & 25.5 \\
\hline A & $6-10$ & 1 & 0.16 & --- & 0.94 & 25.5 \\
\hline $\mathrm{BE}$ & $10-24$ & 1 & 1.38 & --- & 0.48 & --- \\
\hline Bt1 & $24-37$ & $\mathrm{cl}$ & 1.61 & --- & 0.39 & 0.12 \\
\hline Bt2 & $37-59$ & $\mathrm{cl}$ & 1.60 & depletions & 0.40 & --- \\
\hline Btxl & $59-80$ & 1 & 1.84 & masses and depletions & 0.31 & 0.02 \\
\hline Btx2 & $80-117$ & sicl & 2.00 & masses & 0.25 & 0.01 \\
\hline $\mathrm{Cr}$ & $117-150+$ & (1) & 2.19 & --- & 0.17 & 0.01 \\
\hline \multicolumn{7}{|c|}{ Footslope south $\left(39^{\circ} 38^{\prime} 59.80^{\prime \prime} \mathrm{N}, 79^{\circ} 47^{\prime} 24.40^{\prime \prime} \mathrm{W}\right.$; elevation $\left.636.6 \mathrm{~m}\right)$} \\
\hline Oi & $0-3$ & leaf litter & 0.05 & --- & 0.96 & --- \\
\hline $\mathrm{Oe}$ & $3-6$ & mkpt & 0.09 & --- & 0.93 & 9.0 \\
\hline A & $6-10$ & sil & 0.45 & --- & 0.83 & 9.0 \\
\hline $\mathrm{BE}$ & $10-17$ & sil & 1.14 & --- & 0.57 & --- \\
\hline Bt1 & $17-25$ & sil & 1.32 & --- & 0.50 & -- \\
\hline Bt2 & $25-52$ & sil & 1.64 & depletions & 0.38 & 14.1 \\
\hline Btxl & $52-72$ & 1 & 1.79 & masses and depletions & 0.32 & 0.01 \\
\hline Btx2 & $72-116$ & 1 & 1.68 & masses & 0.37 & 0.01 \\
\hline Btx3 & $116-150+$ & sil & 1.71 & masses & 0.35 & --- \\
\hline \multicolumn{7}{|c|}{ Footslope north $\left(39^{\circ} 38^{\prime} 57.10^{\prime \prime} \mathrm{N}, 79^{\circ} 47^{\prime} 25.10^{\prime \prime} \mathrm{W}\right.$; elevation $\left.635.9 \mathrm{~m}\right)$} \\
\hline $\mathrm{Oi}$ & $0-3$ & leaf litter & 0.06 & --- & 0.95 & --- \\
\hline A & $3-10$ & 1 & 0.74 & --- & 0.72 & 4.6 \\
\hline BA & $10-18$ & sil & 1.48 & --- & 0.44 & --- \\
\hline Bt1 & $18-38$ & $\mathrm{cl}$ & 1.61 & --- & 0.39 & 0.94 \\
\hline Bt2 & $38-65$ & 1 & 1.46 & depletions & 0.45 & --- \\
\hline Btxl & $65-74$ & 1 & 1.72 & masses and depletions & 0.35 & --- \\
\hline Btx2 & $74-110$ & 1 & 1.63 & --- & 0.38 & 0.01 \\
\hline Btx3 & $110-150+$ & 1 & 1.84 & --- & 0.31 & --- \\
\hline \multicolumn{7}{|c|}{ Backslope north $\left(39^{\circ} 38^{\prime} 51.90^{\prime \prime} \mathrm{N}, 79^{\circ} 47^{\prime} 29.40^{\prime \prime} \mathrm{W}\right.$; elevation $\left.666.1 \mathrm{~m}\right)$} \\
\hline $\mathrm{Oi}$ & $0-3$ & leaf litter & 0.16 & --- & 0.88 & -- \\
\hline A & $3-8$ & sil & 0.60 & --- & 0.77 & 15.1 \\
\hline BA & $8-17$ & sil & 1.35 & --- & 0.49 & --- \\
\hline Bt1 & $17-33$ & sil & 1.67 & --- & 0.37 & 4.7 \\
\hline Bt2 & $33-58$ & sicl & 1.55 & masses and depletions & 0.42 & 4.7 \\
\hline Btxl & $58-72$ & sic & 1.65 & masses and depletions & 0.38 & 0.07 \\
\hline Btx2 & $72-96$ & sicl & 1.51 & masses and depletions & 0.43 & 0.07 \\
\hline Btx3 & $96-123$ & sicl & 1.87 & depletions & 0.29 & -- \\
\hline Btx4 & $123-150+$ & sic & 1.78 & depletions & 0.33 & --- \\
\hline \multicolumn{7}{|c|}{ Summit north $\left(39^{\circ} 38^{\prime} 48.40^{\prime \prime} \mathrm{N}, 79^{\circ} 47^{\prime} 28.90^{\prime \prime} \mathrm{W}\right.$; elevation $\left.676.2 \mathrm{~m}\right)$} \\
\hline $\mathrm{Oi}$ & $0-6$ & leaf litter & 0.1 & --- & 0.92 & --- \\
\hline A & $6-14$ & sicl & 0.69 & --- & 0.74 & 13.8 \\
\hline BA & $14-22$ & $\mathrm{cl}$ & 1.28 & --- & 0.52 & --- \\
\hline Bt1 & $22-50$ & $\mathrm{cl}$ & 1.58 & --- & 0.40 & -- \\
\hline Bt2 & $50-60$ & $\mathrm{cl}$ & 1.51 & --- & 0.43 & 0.09 \\
\hline BC & $60-68$ & 1 & 1.67 & depletions & 0.37 & 0.01 \\
\hline $\mathrm{Cr}$ & 68-108 & (1) & 1.78 & --- & 0.33 & 0.01 \\
\hline $\mathrm{R}$ & $108+$ & --- & --- & --- & --- & --- \\
\hline
\end{tabular}


The bulk density of the first mineral horizon, designated as A (Table 3-1), is low at all site locations. The bulk density range of the A horizons is $0.16 \mathrm{~g} \mathrm{~cm}^{-3}$ to $0.74 \mathrm{~g} \mathrm{~cm}^{-3}$. With depth, the bulk density increases into the $\mathrm{Bt} 2$ horizon at all sites. The bulk density range of the Bt2 horizons is $1.46 \mathrm{~g} \mathrm{~cm}^{-3}$ to $1.67 \mathrm{~g} \mathrm{~cm}^{-3}$. The bulk density of the first fragipan horizon described at each site, Btx or Btx1 horizon, has a range of $1.65 \mathrm{~g} \mathrm{~cm}^{-3}$ to $1.93 \mathrm{~g} \mathrm{~cm}^{-3}$. Grossman and Carlisle (1969) state that the bulk density of most eastern U.S. fragipan soils exceeds $1.60 \mathrm{~g} \mathrm{~cm}^{-3}$. Ciolkosz and Waltman (2000) found bulk densities of the fragipan horizon to be less than 1.60 when in loess soils. The bulk density of the deepest horizon described at all fragipan sites ranges from $1.71 \mathrm{~g} \mathrm{~cm}^{-3}$ to $2.19 \mathrm{~g} \mathrm{~cm}^{-3}$. The bulk density of the deepest horizon described (Cr) in the non-fragipan soil at the Summit (north) is $1.78 \mathrm{~g} \mathrm{~cm}^{-3}$. At all sites the bulk density increases with depth into the fragipan layers. The implication of these results is that vertical water movement is expected to be restricted at the contact with the fragipan horizon, and downward movement will stall causing it to move laterally at the contact. McDaniel et al. (2001) credited the dense properties of the fragipan and a relatively thin overlying soil with fluctuating water tables near the soil surface many times throughout the growing season. Ciolkosz and Waltman (2000) attributed the orientation and close-packing of soil particles of the fragipan the restriction of root growth and limiting water movement, creating seasonally saturated conditions.

At all site locations with fragipans described, redoximorphic depletions occur in the horizon above the fragipan (Table 3-1). The range of depth to the redoximorphic features (from the ground surface) ranges from $25 \mathrm{~cm}$ to $47 \mathrm{~cm}$. The range of depth to the top of the first fragipan horizon at all locations is from $52 \mathrm{~cm}$ to $66 \mathrm{~cm}$. At the Summit (north), 
which has no fragipan, redoximorphic depletions occur in the horizon above the paralithic contact at $60 \mathrm{~cm}$ depth from the surface. The depth to the paralitihic contact is $68 \mathrm{~cm}$. Pedologically, the presence of redoximorphic features leads to the expectation that water is perching above the fragipan and the paralithic contact for a significant period of time during the growing season. Jacobs et al. (2002) stated that the determination of whether a soil is saturated at some time during the growing season can be interpreted from the soil morphology. Morgan and Stolt (2006) linked redoximorphic features to seasonal high water tables and further make the case that soil morphology be used when making land-use decisions. Others have contributed to the body of knowledge that establishes a positive correlation between the presence of water and redoximorphic features described as evidence of pedological development (Boersma et al., 1972; Simonson and Boersma, 1972; Vepraskas et al., 1974; Veneman et al., 1976; Richardson et al., 1992; Thompson et al., 1998; Szogi and Hudnall, 1998; D'Amore et al., 2000; and references therein).

\subsection{Volumetric Water Content (vol vol ${ }^{-1}$ ) and Total Porosity}

The relationship of volumetric water content (VWC) to soil properties is evident throughout the literature. Volumetric water content was derived from gravimetric water and bulk density by Pachepsky et al. (2006) to study the usefulness of pedotransfer functions in hydropedology. Surface and subsurface VWC was utilized by Lin et al. (2006) to examine temporal changes in soil moisture at dry and wet sites. However, the direct use of VWC toward the understanding of hydrological processes may be limited for some research. While Lin et al. (2006) discovered daily VWC across a catchment helpful in their determination of spatial and temporal variability they also found their "wet sites" maintained consistently high content of moisture. Due to the high percentages of 
redoximorphic features encountered at all site locations combined with the relatively higher bulk densities with depth (restricting downward movement of water) within these soils, it was predicted that the study site would be wet for a long period of time. Therefore, the VWC data would best be utilized for the determination of the relative degree of saturation at each soil horizon, expressed as percent saturation. In this way, a relative comparison of soil moisture content could made at the precise moisture content when values fell below saturation. Water-filled pores are the total volume of pore space (total porosity) occupied by water. Total porosity is calculated by:

$$
\text { Total porosity }=(1-(\text { bulk density } / \text { particle density }))
$$

The relationship between total porosity and VWC is given as:

$$
\text { Percent saturation }=(\text { VWC } / \text { total porosity }) \times 100
$$

Particle density values used in equation [1] are $2.65 \mathrm{~g} \mathrm{~cm}^{-3}$ for the mineral horizons and $1.30 \mathrm{~g} \mathrm{~cm}^{-3}$ for the organic horizons. Total porosity results depicted in Table 3-1 are high in the organic leaf litter (Oi horizon) and the first mineral layer (A horizon) at all site locations. The range in the total porosity of the leaf litter is 0.88 to 0.97 and the range of the first mineral layer is 0.72 to 0.94 . Total porosity declines with depth and at the first fragipan horizon described at each site, Btx or Btx1 horizons, has a range of 0.27 to 0.38 . At the deepest horizon described at all sites ranges from 0.17 to 0.35 . At the Summit (north) the total porosity of the Cr horizon is 0.33 . Lin (2006) found total porosity values decrease with depth. In that study, the total porosity of the Cr horizon was not determined, however, the $\mathrm{C}$ horizons were listed as having values of 0.34 to 0.41 . There is an inverse relationship between bulk density and porosity as well as between bulk density and $\mathrm{K}_{\text {sat }}$. As bulk density increases, the total porosity decreases. Likewise, as bulk density increase, 
the $\mathrm{K}_{\mathrm{sat}}$ decreases (Table 3-1). Further discussion of these relationships occurs in the results of the second research hypothesis (3.8 Hypotheses). There, hillslope wetness comparisons are made utilizing percent saturation by hillslope location.

\subsection{Saturated Hydraulic Conductivity $\left(K_{\text {sat }}\right)$}

Saturated hydraulic conductivity $\left(\mathrm{K}_{\mathrm{sat}}\right)$ measurements were taken in select horizons in situ using compact constant head permeameters (CCHP) (Amoozegar, 1989).

Measurements were taken at each of the six hillslope positions (Table 3-1). The range in $\mathrm{K}_{\mathrm{sat}}$ of the first mineral layer is $4.6 \mathrm{~cm} \mathrm{~h}^{-1}$ to $25.5 \mathrm{~cm} \mathrm{~h}^{-1}$. The range in $\mathrm{K}_{\text {sat }}$ in the horizons above the fragipan, and above the paralithic contact at the non-fragipan site, is $0.01 \mathrm{~cm} \mathrm{~h}^{-1}$ to $14.1 \mathrm{~cm} \mathrm{~h}^{-1}$. The range in $\mathrm{K}_{\text {sat }}$ in the fragipan horizons at all locations is $0.01 \mathrm{~cm} \mathrm{~h}^{-1}$ to $0.07 \mathrm{~cm} \mathrm{~h}^{-1}$. The $\mathrm{K}_{\mathrm{sat}}$ of the Summit (north), non-fragipan soil is $0.01 \mathrm{~cm} \mathrm{~h}^{-1}$. As expected, the saturated hydraulic conductivity $\left(\mathrm{K}_{\text {sat }}\right)$ values decrease with increasing depth at all locations. $\mathrm{K}_{\mathrm{sat}}$ values correspond to high conductivity at the surface to low or moderately low once depth to the fragipan (or paralithic) contact is reached. The first mineral layer (A horizon) at each location has the highest $\mathrm{K}_{\mathrm{sat}}$ and collectively fall within the USDA $\mathrm{K}_{\mathrm{sat}}$ class of high (Table 3-2). McDaniel et al. (2008) described fragipan soils with surface layers with high $\mathrm{K}_{\text {sat }}$ to be hydrologically very flashy. The $\mathrm{K}_{\mathrm{sat}}$ in the horizons above the fragipan, and above the paralithic contact at the non-fragipan site, bridges multiple $\mathrm{K}_{\mathrm{sat}}$ classes and collectively range from low to high. As expected, the underlying diagnostic horizon identified as fragipan (Btx) as well as the paralithic contact $(\mathrm{Cr})$ were observed having the lowest $\mathrm{K}_{\mathrm{sat}}$ values. The $\mathrm{K}_{\mathrm{sat}}$ in the fragipan as well as the deepest horizons described are low to moderately low. McDaniel and Falen (1994) associated soils with relatively low $\mathrm{K}_{\text {sat }}$ with seasonal perched zones of saturated conditions. Calmon and Day 
(1999), although no $\mathrm{K}_{\mathrm{sat}}$ values were given, state that fragipans with lower $\mathrm{K}_{\mathrm{sat}}$ relative to layers above tend to perch water. The fragipan has a varied bulk density with depth at several site locations but is most variable at the Backslope (north).

Table 3-2: USDA saturated hydraulic conductivity $\left(K_{\text {sat }}\right)$ classes.

\begin{tabular}{lll}
\hline Class & \multicolumn{1}{c}{$\mu \mathrm{m} \mathrm{s}^{-1}$} & \multicolumn{1}{c}{$\mathrm{K}_{\text {sat }}$} \\
\hline Very High & $\geq 100$ & $\geq 36.0$ \\
High & $10-100$ & $3.6-36$ \\
Moderately High & $1-10$ & $0.36-3.6$ \\
Moderately Low & $0.1-1$ & $0.036-0.36$ \\
Low & $0.01-0.1$ & $0.0036-0.036$ \\
Very Low & $<0.01$ & $<0.0036$ \\
\hline \multicolumn{2}{c}{$\quad$ Source: 3rd Ed. Soil Survey Manual (1993) Tables: $3-7,3-8)$}
\end{tabular}

The fragipan at the Backslope (north) location has a bulk density of the four fragipan horizons described (Btx1, Btx2, Btx3, and Btx4) of 1.65, 1.51, 1.87 and $1.78 \mathrm{~g} \mathrm{~cm}^{-3}$. In contrast, the first fragipan horizon described at the Backslope (south) location has a bulk density of $1.84 \mathrm{~g} \mathrm{~cm}^{-3}$ followed by the subsequent fragipan horizon with a bulk density of $2.00 \mathrm{~g} \mathrm{~cm}^{-3}$. Ciolkosz and Waltman (2000), suggested that soils with less dense upper pan layers coupled with the physical observation of decreasing strength of pan properties with depth, exhibit overall pan properties that may be in the process of degradation. Grossman et al. (1959) stated that the encroachment of eluvial material from above onto the fragipan layer degrades the fragipan. Lindbo et al. (2000) argue that fragipan soils with glossic horizons containing albic material along the primary ped faces indicate degradation. At all locations with the exception of the Footslope (south), the uppermost fragipan layers are less dense than the underlying horizons and albic material is described along the primary ped faces. However, without accompanying field observations sufficient to determine 
strength of pan properties described by Ciolkosz and Waltman (2000), this assessment cannot be determined. The soils of this research were described in July when the soil water content is lowest. Determining brittleness properties of dry, firm or very firm soil of the fragipan on site has proven most challenging. The soil pedon descriptions of the fragipan layers lack the description of brittleness that is necessary for the diagnostic horizon of fragipan. Lindbo et al. (1995) describe the brittleness criteria for the confirmation of fragipans as subjective and a function of moisture content and therefore not reliable. Where roots were described in the fragipan layers they were found between ped faces and at top of the peds, never throughout. Clay films, albic material, redoximorphic features and soil structure were all described in these soils. In the soils that exhibit fragipan properties, iron depletions with or without accompanying redoximorphic concentrations are described in the horizon immediately above the fragipan zone (Table 31). This supports the thesis that water is perching on top of the fragipan layer.

\subsection{Precipitation}

Precipitation recorded at the Cooper's Rock State Forest Weather Station (CRSFWS) was $1,344 \mathrm{~mm}$ for the 2009 calendar year and 1,323 $\mathrm{mm}$ for 2010. Mean annual air temperature at CRSF-WS for 2010 was $9{ }^{\circ} \mathrm{C}$. Monthly as well as cumulative precipitation totals for the 2010 calendar year from CRSF-WS and each hillslope location are shown in Table 3-3. 
Table 3-3: Precipitation $(\mathbf{m m})$ recorded at the CRSF-WS and the hillslope gauges for the 2010 calendar year. Temperature data is from the CRSF-WS for the same time period.

\begin{tabular}{|c|c|c|c|c|c|c|c|c|c|c|c|c|c|}
\hline Gauge location & Jan & Feb & Mar & Apr & May & Jun & Jul & Aug & Sep & Oct & Nov & Dec & Cumulative \\
\hline CRSF-WS & 133 & 159 & 114 & 86 & 137 & 123 & 99 & 61 & 83 & 119 & 118 & 92 & 1323 \\
\hline Summit (south) & 94 & 14 & 115 & 95 & 161 & 169 & 104 & 98 & 174 & 95 & 163 & 43 & 1325 \\
\hline Backslope (south) & 112 & 7 & 116 & 103 & 159 & 216 & 124 & 101 & 236 & 147 & 176 & 42 & 1539 \\
\hline Footslope (south) & 92 & 12 & 109 & 92 & 130 & 151 & 82 & 87 & 149 & 76 & 157 & 40 & 1177 \\
\hline Summit (north) & 86 & 12 & 105 & 77 & 150 & 168 & 83 & 89 & 154 & 76 & 160 & 36 & 1196 \\
\hline Temperature $\left({ }^{\circ} \mathrm{C}\right)$ & -5.4 & -5.9 & 3.7 & 11.7 & 15.3 & 19.1 & 21.8 & 20.1 & 18.2 & 10.5 & 4.9 & -7.4 & $\begin{array}{c}\text { MAAT } \\
9\end{array}$ \\
\hline
\end{tabular}

The rain gauges at Backslope (north) and Footslope (north) did not function consistently and were therefore removed from this analysis. Coopers Rock State Forest Weather Station (CRSF-WS) includes a snow water equivalent for precipitation during winter months.

The precipitation values at each gauge, by hillslope location, varied throughout the 2010 year. During the winter months, precipitation was under-recorded when compared to the CRSF-WS, which included a conversion of snow to water equivalent. Precipitation in the form of snowfall was not measured at the hillslope locations. The under-recorded precipitation due to snowfall is well expressed in the month of February (Table 3-3) during which the mean temperature was $-5.9^{\circ} \mathrm{C}$. The CRSF-WS recorded $159 \mathrm{~mm}$ of precipitation which contrasts to only $7 \mathrm{~mm}$ to $14 \mathrm{~mm}$ recorded at the hillslope gauges. During the summer months, precipitation was over-recorded in most cases. A comparison of the data during the summer period (May through October), are shown in Table 3-4. The table compares the difference between CRSF-WS and the hillslope precipitation gauges using the following:

$\%$ difference $=(1-($ monthly precip. at hillslope $/$ monthly precip. at CRSF-WS $)) \times 100$ [3] 
Table 3-4: Precipitation differences (\%) between hillslope gauges and the CRSF-WS for the summer period (May through October) for 2010. Positive values indicate higher precipitation was recorded at the hillslope gauges.

\begin{tabular}{lcccccc}
\hline Gauge location & May & Jun & Jul & Aug & Sep & Oct \\
\hline Summit (south) & 18 & 38 & 5 & 62 & 111 & -20 \\
Backslope (south) & 16 & 76 & 25 & 67 & 186 & 24 \\
Footslope (south) & -5 & 23 & -17 & 44 & 47 & -36 \\
Summit (north) & 10 & 37 & -16 & 47 & -36 \\
\hline
\end{tabular}

The on-site precipitation recorded at each hillslope position during most of the six month summer period was over-recorded (positive values) (Table 3-4). Previous research has shown that spatial variation of throughfall contributes to the variation in observed soil moisture patterns (Keim et al., 2006). To account for the expected uneven distribution of rainfall throughout the watershed, the average of all hillslope gauges was determined and compared to the CRSF-WS (Figure 3-5) for the summer period. The hillslope gauges

Table 3-5: The average of all hillslope rain gauges compared to the CRSF-WS. A positive \% difference reflects higher average precipitation recorded by the hillslope gauges. Negative \% difference values reflect lower average precipitation recorded by the hillslope gauges. Data are May through October, 2010.

\begin{tabular}{lcccccc}
\hline Gauge location & May & Jun & Jul & Aug & Sep & Oct \\
\hline CRSF-WS & 137 & 123 & 99 & 60 & 82 & 119 \\
Hillslope Rain Gauges Average & 150 & 176 & 98 & 94 & 178 & 98 \\
\% difference & 9 & 30 & -1 & 36 & 54 & -21 \\
\hline
\end{tabular}

recorded values that differ from the CRSF-WS and range from over-reporting by as much as $54 \%$ (September) to under-reporting by $21 \%$ (October). The mean of the difference for the entire summer is $18 \%$ over-reported by the hillslope gauges. Ford and Vose (2007) have linked canopy interception with soil moisture. However, their research predicted a decrease in precipitation below the canopy. The differences between the onsite rain gauges 
on the hillslope and the CRSF-WS may be attributed to the distance of the latter from the watershed.

\subsection{Streamflow}

The watershed streamflow varied throughout the course of this study. Figure 3-1 shows the hydrograph of the average daily measurement of stage height $(\mathrm{cm})$ for the 21 month period of observation.

\section{Stream Hydrograph}

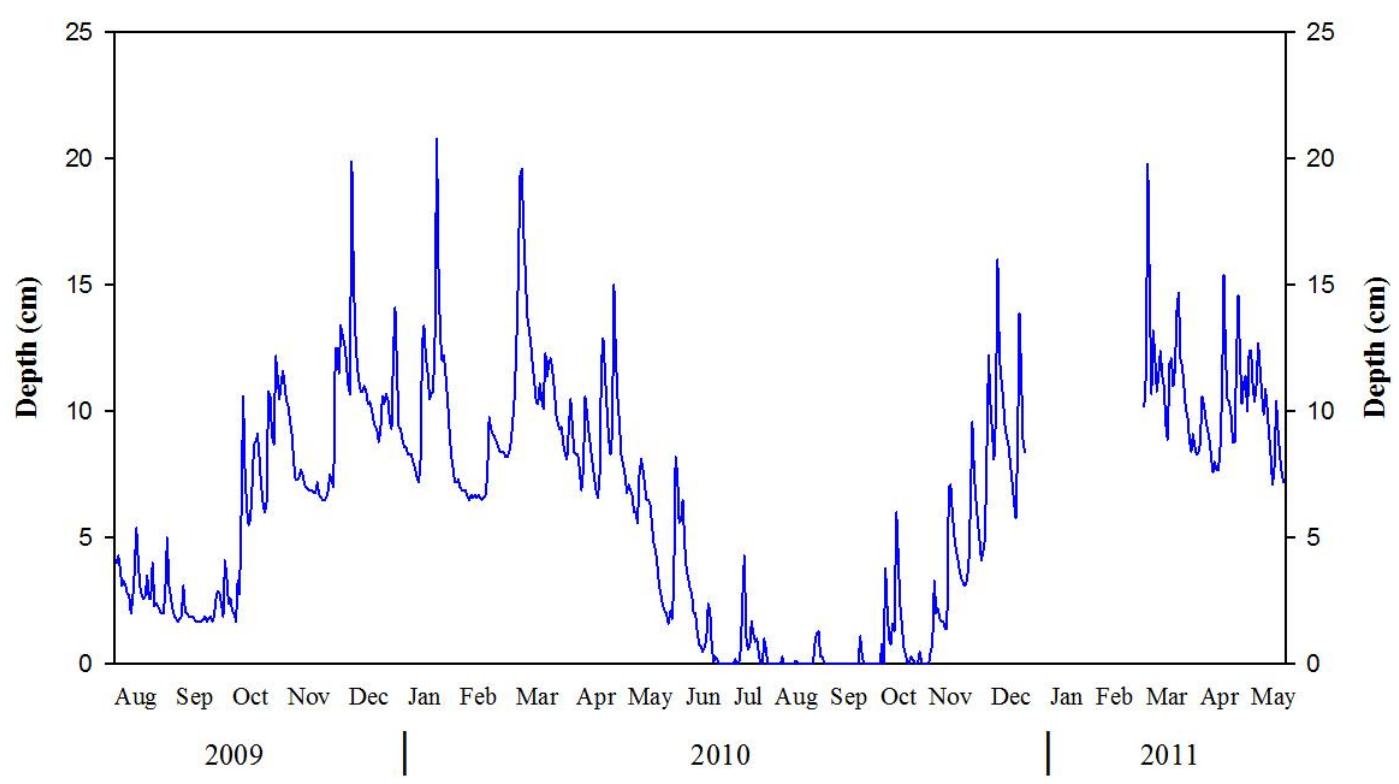

Figure 3-1: Stream stage hydrograph of the 21 months of observation. (Data shown are August 2009 through April 2011. Data is unavailable for December 17, 2010 through February 19, 2011.)

Although the relationship between stream stage and discharge is non-linear, a linear regression analysis was used due to the relatively low number of salt-tracer experiments performed. The timing of being on site during high flow periods proved difficult and therefore fewer experiments were performed. Consequently, linear regression was chosen as the best estimate for discharge. Knowing the depth of water in the stream and the 
associated flow rate of the stream during those known periods (Figure 3-2), a regression equation was determined. The prediction of discharge $\left(\mathrm{L} \mathrm{s}^{-1}\right)$ is calculated from the regression equation: $y=0.48 x+1.85$ with an $r^{2}$ of 0.91 . The explanatory variable in the equation is the stream stage $(\mathrm{cm})$ of the water recorded throughout the duration of the study.

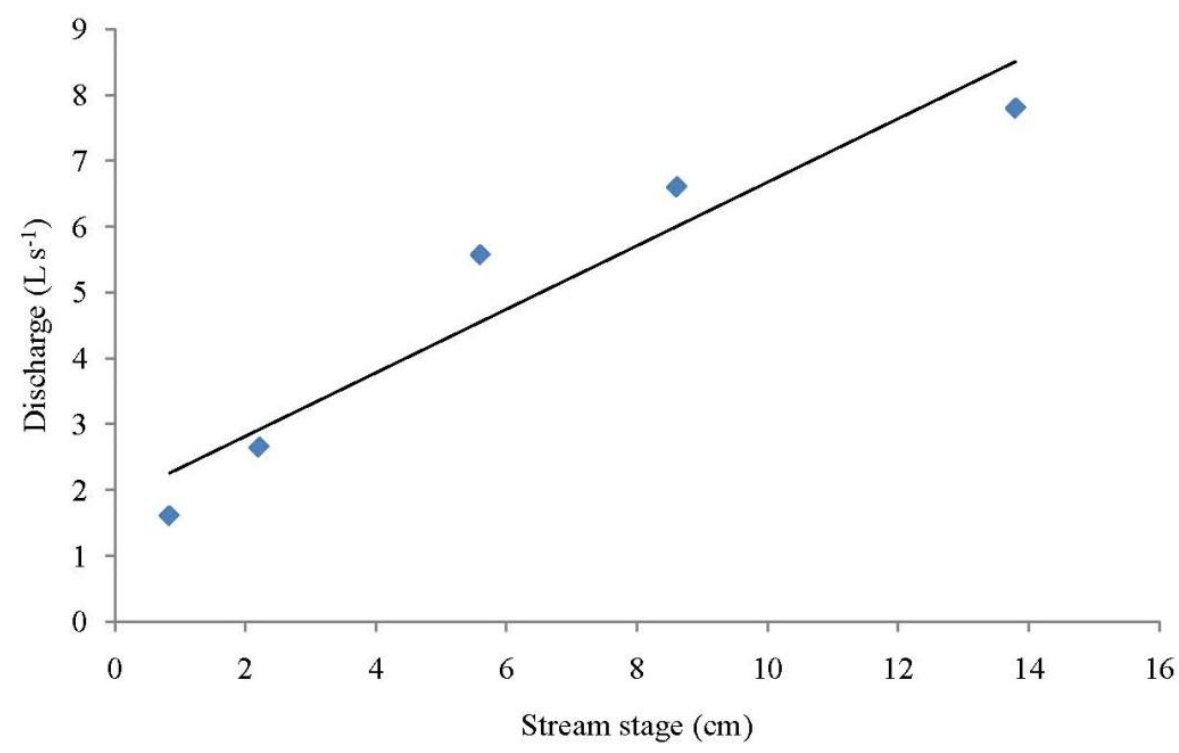

Figure 3-2: Volume flow rate $\left(\mathrm{L} \mathrm{s}^{-1}\right)$ was determined at various stream stages $(\mathrm{cm})$ using salt tracers. The linear regression equation is: $y=0.48 x+1.85 ; r^{2}=0.91$. The explanatory variable is the stage $(\mathrm{cm})$ of water recorded throughout the duration of the study.

From this equation, discharge is estimated as a function of stage for the entire period of the study (Table 3-6). While performing the mass balance assessment of recovery of total salts utilized in each experiment, observed measurement error increased with decreasing flow rate. Recovery (grams of salt) was calculated by determining the amount of sodium chloride salts $\left(\mathrm{g} \mathrm{s}^{-1} \mathrm{~L}^{-1}\right)$ that was detected at the EC sensor throughout the duration of the experiment, multiplied by the flow rate $\left(\mathrm{L} \mathrm{s}^{-1}\right)$ of the stream. The resultant mass of sodium chloride detected was then divided by the total mass of sodium 
chloride originally added to the stream. During high flow, the mass recovery was $>99 \%$, while low flow periods dropped to just over 95\%, sodium chloride recovered.

Table 3-6: Stream stage $(\mathrm{cm})$ and corresponding monthly average discharge $\left(\mathrm{L} \mathrm{s}^{-1}\right)$ for the length of the study.

\begin{tabular}{lccc}
\hline \multirow{2}{*}{ Date } & & Stage $(\mathrm{cm})$ & Discharge $\left(\mathrm{L} \mathrm{s}^{-1}\right)$ \\
\hline \multirow{3}{*}{2009} & Aug & 2.86 & 3.23 \\
& Sep & 2.07 & 2.85 \\
& Oct & 6.9 & 5.18 \\
& Nov & 7.89 & 5.66 \\
& Dec & 11.3 & 7.30 \\
\hline \multirow{4}{*}{2010} & Jan & 10.80 & 7.06 \\
& Feb & 7.49 & 5.46 \\
& Mar & 11.73 & 7.51 \\
& Apr & 8.99 & 6.19 \\
& May & 6.8 & 5.13 \\
& Jun & 2.5 & 3.06 \\
& Jul & 0.54 & 2.11 \\
& Aug & 0.14 & 1.92 \\
& Sep & 0.21 & 1.95 \\
& Oct & 1.15 & 2.41 \\
& Nov & 5.70 & 4.60 \\
& Dec & 9.76 & 6.56 \\
\hline \multirow{6}{*}{2011} & Jan & no data & --- \\
& Feb & 10.19 & 6.76 \\
& Mar & 10.82 & 5.07 \\
& Apr & 8.28 & 5.84 \\
\hline
\end{tabular}

No data available for Jan 2011

Dec 2010 and Feb 2011 are partial month averages

The average monthly stream stage for the 21 month period suggests seasonal trends. The winter months (November through April) on average, have the greatest amount of stream discharge. The highest monthly average recorded was March 2010 with $11.73 \mathrm{~cm}$ of height which corresponds to $7.51 \mathrm{~L} \mathrm{~s}^{-1}$ of discharge. It is worth noting that monthly precipitation is Forest vegetation is expected to reach peak evapotranspiration rates during the warmest time periods of June through September (see Table 3-2 for 
temperature data). As the demand for water use by the vegetation increases, the amount of water available to move through the soil and into the stream decreases. Rowe (1963) reported an increase in streamflow after deeply rooted trees were removed. Ford and Vose (2007) conclude that a reduction in evapotranspiration increases discharge. Conversely, active tree growth decreases streamflow. As Table 3-6 shows, stream discharge rates are lowest in the summer. The lowest monthly average stage was $0.14 \mathrm{~cm}$ (August 2010) which corresponds to $1.92 \mathrm{~L} \mathrm{~s}^{-1}$.

\subsection{Soil Temperature}

Soil temperature varies by location and depth. Figure 3-3 shows the average soil temperature at each hillslope location at the surface $(5 \mathrm{~cm})$ by month for the 2010 calendar year. On an annual basis, the average surface temperature is: Summit (south) $11.0{ }^{\circ} \mathrm{C}$; Backslope (south) $11.1^{\circ} \mathrm{C}$; Footslope (south) $11.3^{\circ} \mathrm{C}$; Footslope (north) $10.6{ }^{\circ} \mathrm{C}$; Backslope (north) $10.9^{\circ} \mathrm{C}$; and Summit (north) $10.6^{\circ} \mathrm{C}$.

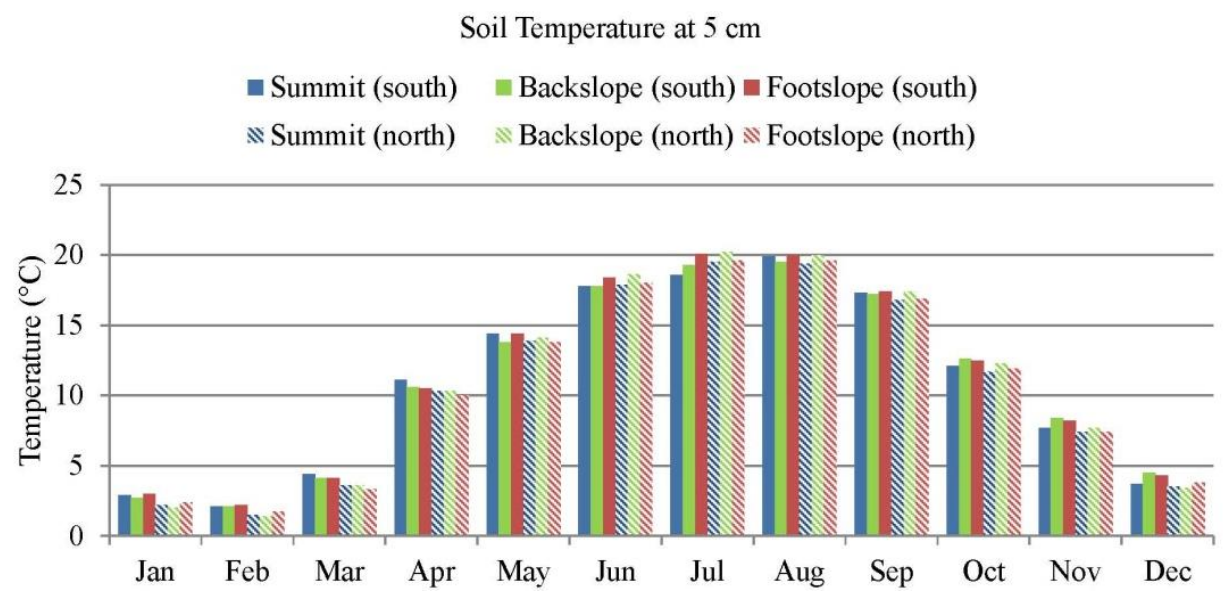

Figure 3-3: Mean monthly, near surface soil temperature at hillslope location. (Data shown are 2010 calendar year)

Mean annual soil temperature (MAST) for the purpose of soil classification is taken at $50 \mathrm{~cm}$ depth (Soil Survey Staff, 2010). Figure 3-4 depicts the average soil temperature 
at each hillslope location at $50 \mathrm{~cm}$ by month for the 2010 calendar year. On an annual basis, the average temperature at $50 \mathrm{~cm}$ by location is: Summit (south) $11.3{ }^{\circ} \mathrm{C}$; Backslope (south) $11.4{ }^{\circ} \mathrm{C}$; Footslope (south) $11.2^{\circ} \mathrm{C}$; Footslope (north) $10.7^{\circ} \mathrm{C}$; Backslope (north) $10.6^{\circ} \mathrm{C}$; and Summit (north) $10.8^{\circ} \mathrm{C}$.

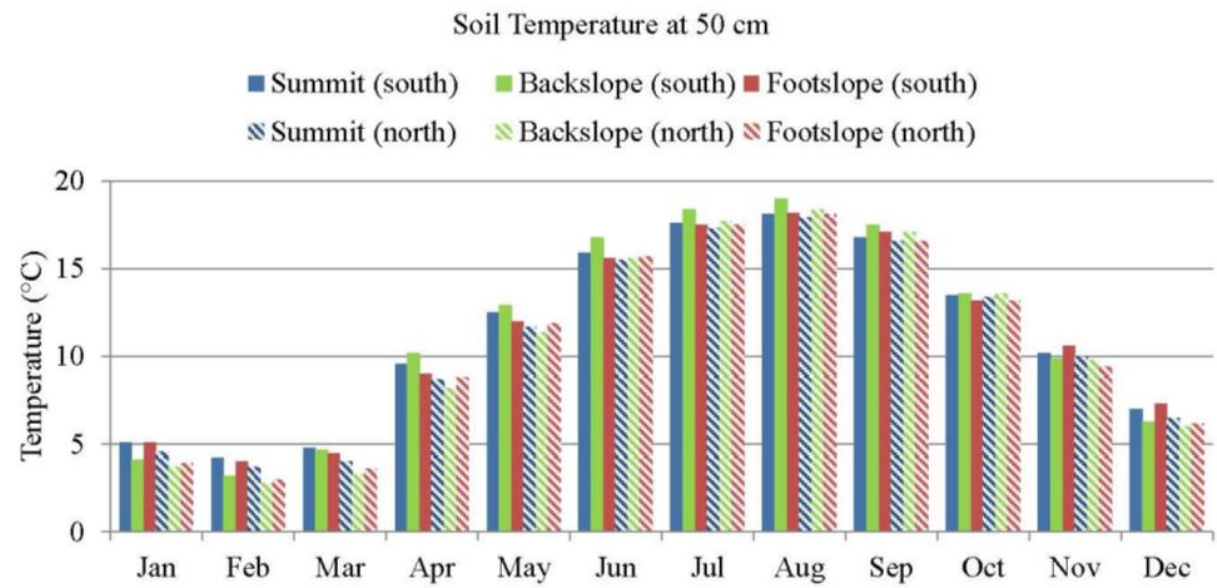

Figure 3-4: Mean monthly soil temperature used to derive mean annual soil temperature (MAST) used in soil classification by hillslope location. (Data shown are 2010 calendar year)

Differences in soil temperature by hillslope location are negligible. Noteworthy, however, is that MAST $(50 \mathrm{~cm})$ is consistently warmer at all south-facing locations compared to the north-facing counterpart location. At the summit location, the southfacing temperature at $50 \mathrm{~cm}$ is $0.5^{\circ} \mathrm{C}$ warmer than at the same depth at the north-facing location. Similar results are found at the other paired locations. The Backslope (south) is $0.8^{\circ} \mathrm{C}$ warmer than Backslope (north) and Footslope (south) is $0.5^{\circ} \mathrm{C}$ warmer than Footslope (north). The average MAST of all locations together is $11^{\circ} \mathrm{C}$ which puts these soils into the Mesic temperature regime for soil classification purposes (Soil Survey Staff, 2010). 


\subsection{Hypotheses Testing}

\subsubsection{Hypothesis $\mathbf{H}_{1}$ :}

The first hypothesis involves the relationship between soils with fragipan properties and the movement of water within the soil profile. The specific research hypothesis is: The fragipan will restrict the downward movement of water $\left(H_{1}\right)$. Results show that the effects of the fragipan layer on perching of water varied by hillslope position. The fragipan horizons at the summit and footslope positions perched water for significant periods of time throughout the course of observation, while neither backslope location, on a daily average basis, perched above the fragipan at any time.

At the Summit (south), the piezometric data on a daily average basis (Figure 3-5) shows that there is water present above the fragipan horizon throughout much of the winter period (November through April) and into the early part (May and early June) of the summer period. The average daily thickness of water perching above the fragipan for the winter period of 2010 was $3.4 \mathrm{~cm}$ with the maximum depth of $25 \mathrm{~cm}$ recorded in March. The average daily thickness of water perching above the fragipan for the summer period (May through October) of 2010 was $0.3 \mathrm{~cm}$ with the maximum depth of $22.5 \mathrm{~cm}$ recorded in May. The average daily perching of water above the fragipan horizon for the year was $1.8 \mathrm{~cm}$ of thickness. 


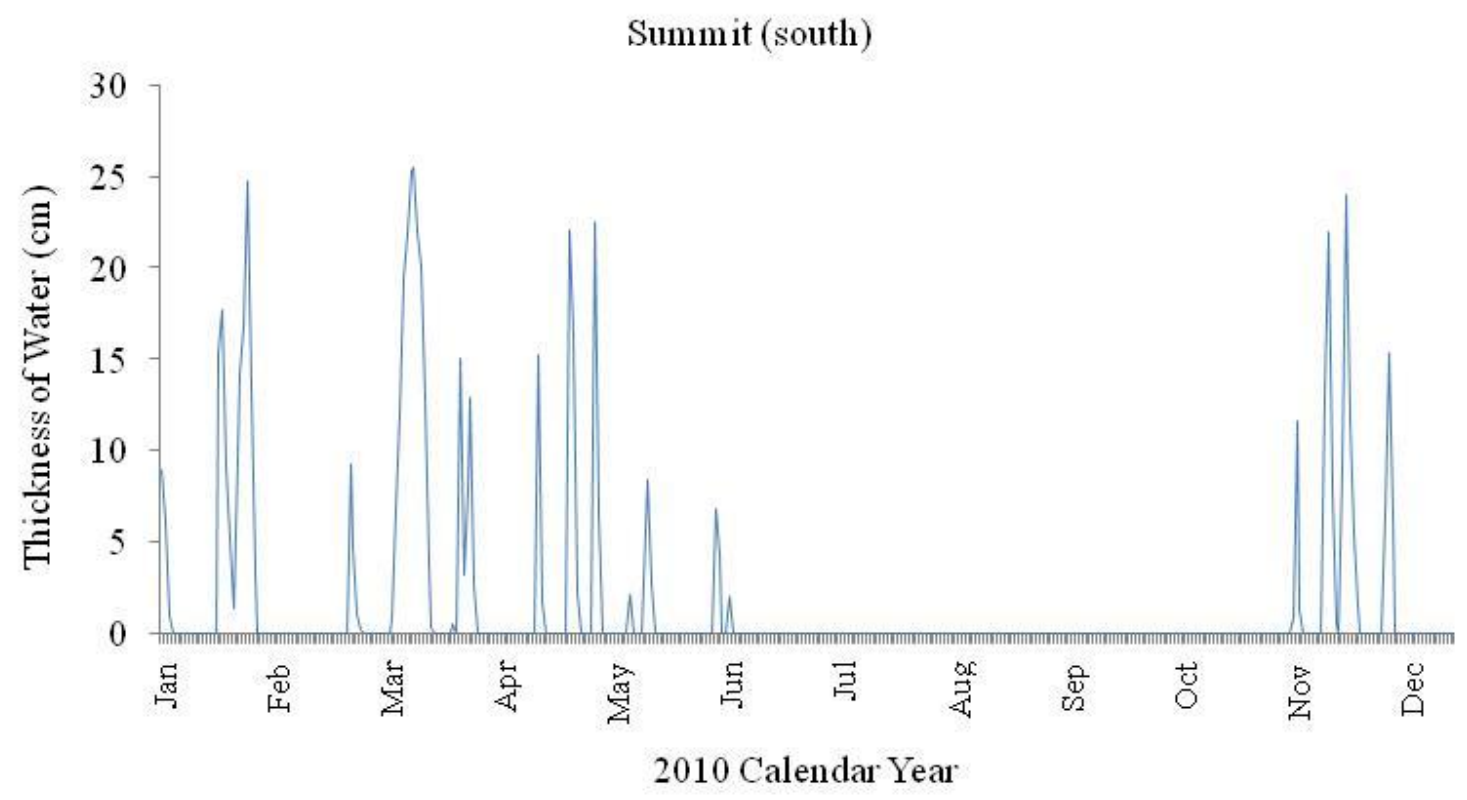

Figure 3-5: Daily average thickness of water perching above the fragipan as measured at the Summit (south) hillslope location.

The piezometric data on a daily average basis for the Footslope (south) location and Footslope (north) location demonstrate water perching above the fragipan. Both footslope locations show water present above the fragipan horizon throughout much of the winter period (November through April) and into the early part (May and June) of the summer period. At the Footslope (south) location (Figure 3-6), the average daily thickness of water perching above the fragipan for the winter period of 2010 was $7.9 \mathrm{~cm}$ with the maximum depth of $52 \mathrm{~cm}$ recorded in March. The average daily thickness of water perching above the fragipan for the summer period (May through October) of 2010 was $0.8 \mathrm{~cm}$ with the maximum depth of $27 \mathrm{~cm}$ recorded in May. The average daily perching of water above the fragipan horizon for the year was $4.2 \mathrm{~cm}$ of thickness. 


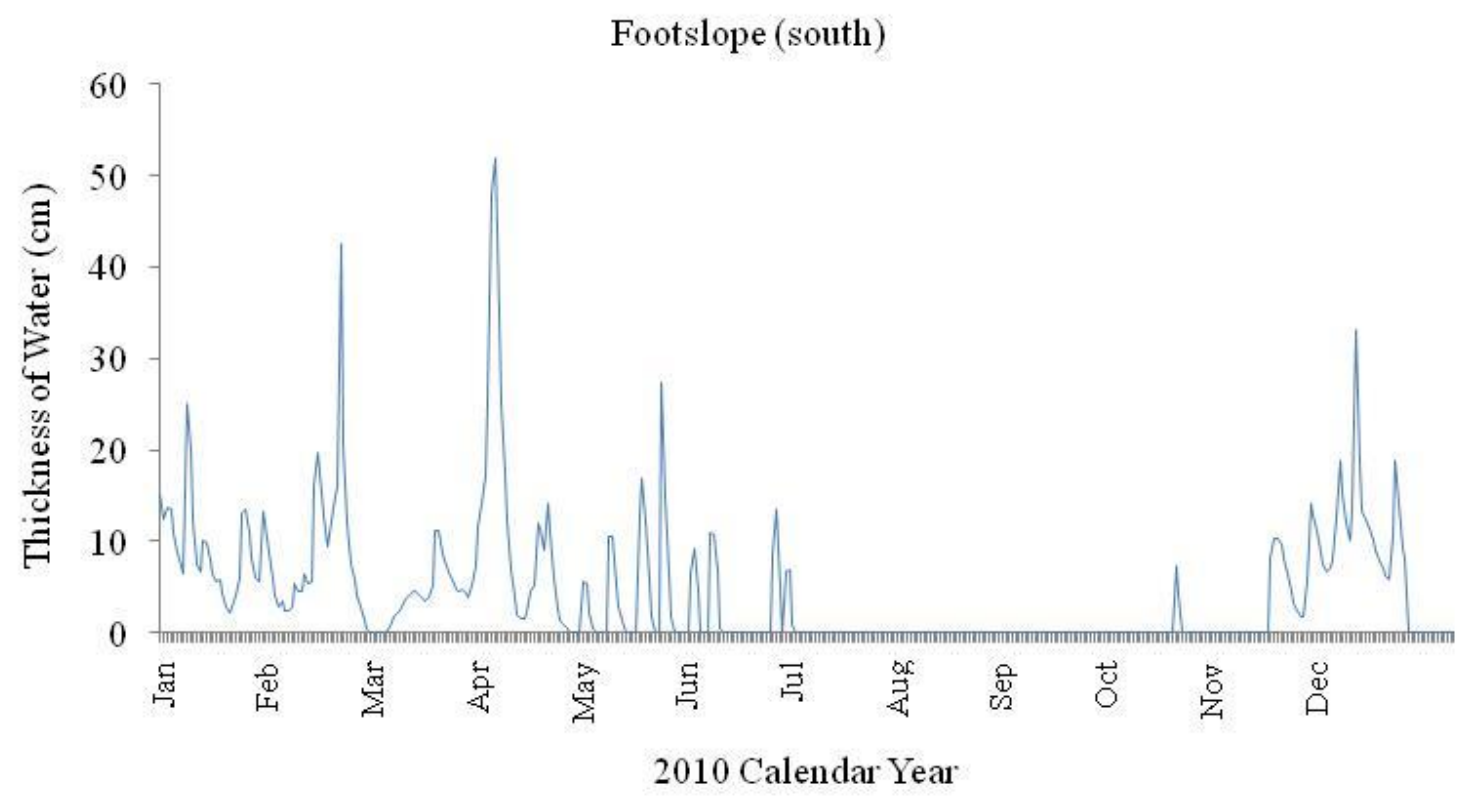

Figure 3-6: Daily average thickness of water perching above the fragipan as measured at the Footslope (south) hillslope location.

At the Footslope (north) location (Figure 3-7), the average daily thickness of water perching above the fragipan for the winter period of 2010 was $2.6 \mathrm{~cm}$ with the maximum depth of $42 \mathrm{~cm}$ recorded in March. The average daily thickness of water perching above the fragipan for the summer period (May through October) of 2010 was $0.2 \mathrm{~cm}$ with the maximum depth of $27 \mathrm{~cm}$ recorded in May. The average daily perching of water above the fragipan horizon for the year was $1.3 \mathrm{~cm}$ of thickness. 


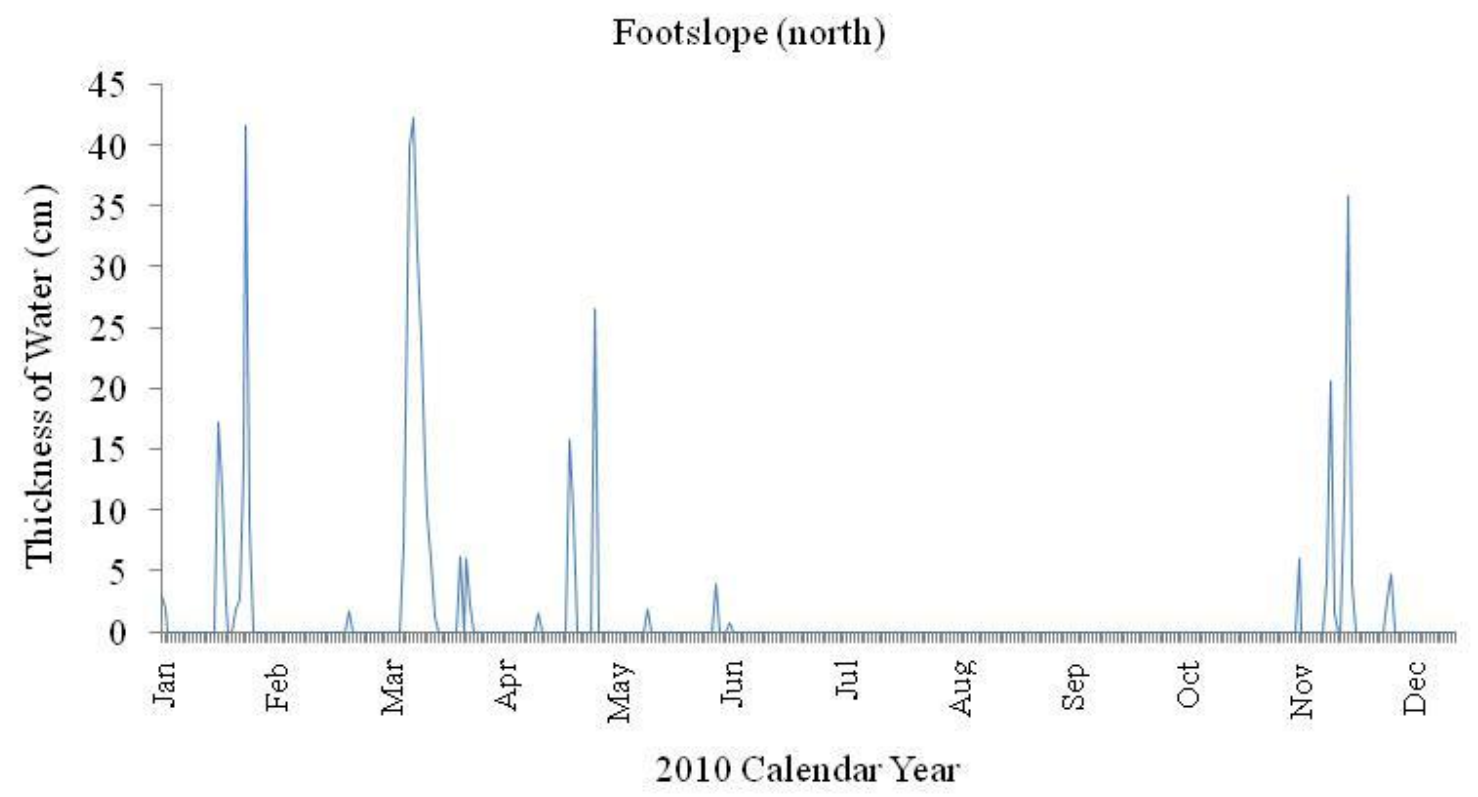

Figure 3-7: Daily average thickness of water perching above the fragipan as measured at the Footslope (north) hillslope location.

These results are consistent with previous research that has established a link between fragipan soils and the perching of water on top of the fragipan. Heald and Rogowski (1977) described perching of water above the fragipan as well as below the fragipan on non-fractured bedrock, particularly evident after storm events. McDaniel and Falen (1994) found greater amount of water perching above the fragipan immediately following snowmelt periods. Calmon and Day (1999) found perching water tables for brief periods of time that if water levels were not measure frequently, would have gone unrecorded. Karathanasis et al. (2003) concluded that water perching above the fragipan was most abundant during late winter and early spring. McDaniel et al. (2008) found perching of water on top of the fragipan that they attributed to lower Ksat values of the fragipan compared to the horizons nearer the surface. 


\subsubsection{Hypothesis $\mathbf{H}_{2}$ :}

The second hypothesis is related to hillslope position and the amount of saturation of the fragipan soils at each position. The specific research hypothesis is: The footslope position will be the wettest location on the hillslope $\left(\mathrm{H}_{2}\right)$. Results show the footslope position to be the wettest followed by the summit. The driest location was at the backslope location. The results prove the hypothesis that the footslope position is the wettest location on the hillslope.

The monthly average thickness of water recorded at the deepest piezometers by hillslope location was used to determine the percent of water by hillslope position (Figure 3-8). The results are that the footslope positions (north and south) together, account for 63-100\% (monthly average), of the water at the deep piezometers accounted for at all hillslope locations, for the 2010 calendar year. The summit location accounts for 14-33\% of the water examined in this way. And the backslope location accounts for just $4 \%$ of the sum of the water thickness, monthly average, at all sites combined. Similar results were reported by Calmon and Day (1999) where they found the footslope position to have the highest number of days of saturation, followed by the summit position. 


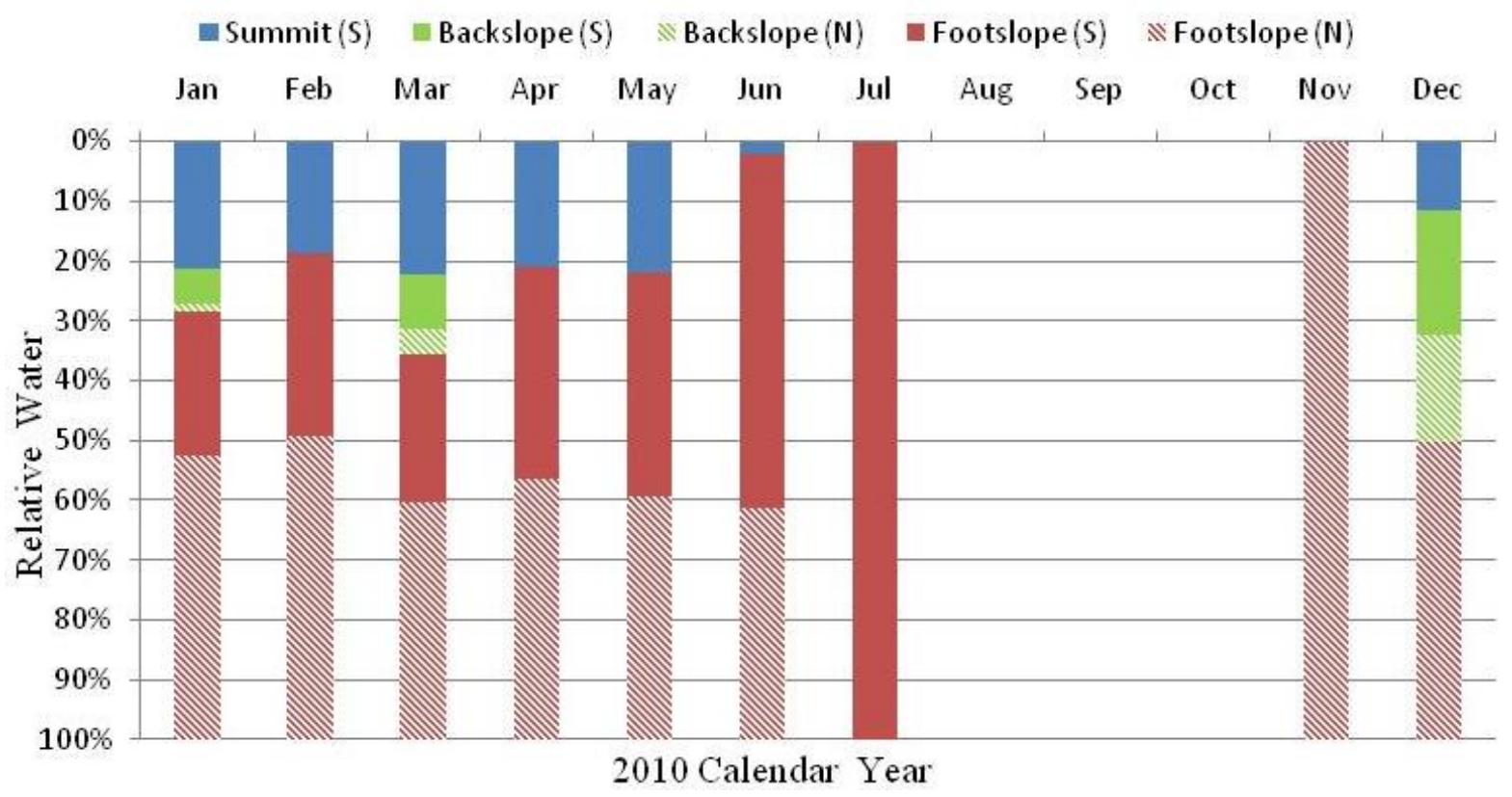

Figure 3-8: Percent of the sum of thickness of water recorded at the deepest piezometers by hillslope location.

Percent saturation (described in section 3.2) comparisons of the first fragipan horizon by hillslope location (Figure 3-9) reveal that the footslope locations had the highest percentage saturation in all months of observation. 


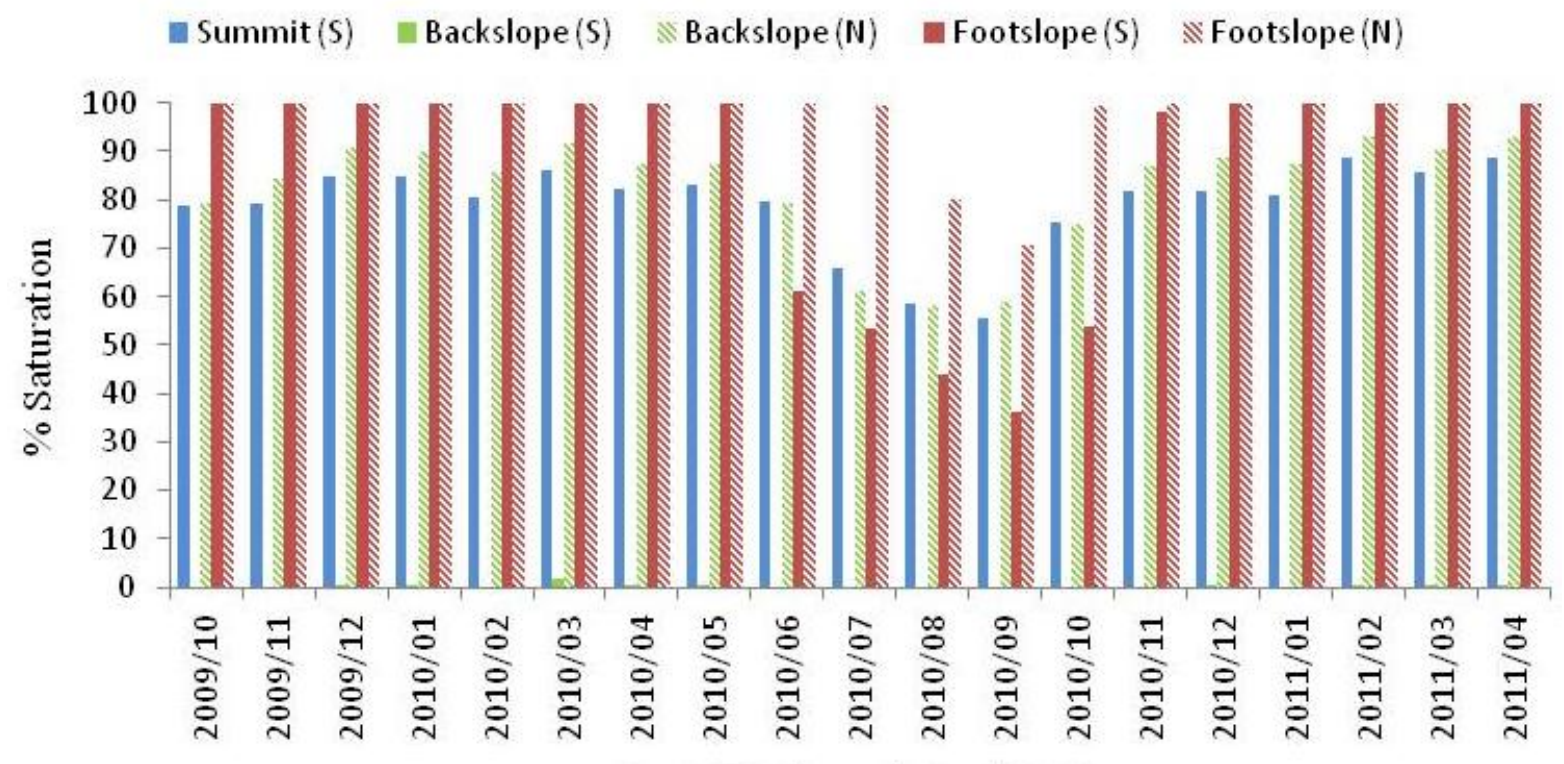

Oct 2009 through April 2011

Figure 3-9: Percent saturation of the fragipan horizon comparisons at hillslope locations.

At no time did any of the other hillslope position locations exhibit saturated conditions for an entire month. These results confirm the observations by Karathanasis et al. (2003) where they found the longest saturated conditions at the lowest positions on the landscape. The Summit (south), during the wettest two months recorded $88 \%$ and $89 \%$ saturation (Summit north location does not have a fragipan horizon and therefore was not included in this analysis). The Backslope (south) position showed very little saturation while 93\% saturation was recorded at the Backslope (north).

\subsubsection{Hypothesis $\mathrm{H}_{3}, \mathrm{H}_{4}$ :}

The third and fourth research hypotheses compare the fragipan soil and the nonfragipan soil found on site, with their respective thickness and duration of perched water, as well as their flashy response to storm events. Fragipan soils will perch less water and for shorter duration than the paralithic contact soil $\left(\mathrm{H}_{3}\right)$; and fragipan soils will react faster to storm events (i.e., more flashy) than the paralithic contact soil $\left(\mathrm{H}_{4}\right)$. Results 
comparing rainfall events with the piezometric head (thickness of water) data indicate that the fragipan soil perched less water and for shorter duration than the non-fragipan (paralithic contact) soil. Results also determined that fragipan soils react faster (flashy) to storm events. During the 2010 calendar year, 20 rainfall event periods (storm events) occurred in which $25 \mathrm{~mm}$ or more precipitation was recorded at the hillslope rain gauges (Table 3-7). Of the 20 storm events 11 had no effect on the thickness of water perching at the summit locations either at Summit (south) location with the fragipan or the Summit (north) location with the paralithic (non-fragipan) materials. During the nine storm events that had an effect on the thickness of water perching, the average thickness of the fragipan soil prior to each storm event was $5.7 \mathrm{~cm}$ with a range of zero to $22 \mathrm{~cm}$, while the paralithic soil recorded a range of zero to $38 \mathrm{~cm}$ with an average thickness of $10.7 \mathrm{~cm}$. The storms resulted in an average peak thickness of water perching above the fragipan of 18 $\mathrm{cm}$, with a range of zero to $26 \mathrm{~cm}$. The paralithic soil experienced an average thickness increase of $29.6 \mathrm{~cm}$ with a range from $5 \mathrm{~cm}$ to $47 \mathrm{~cm}$. The average flashy response (the time from the onset of the storm to the peak in the hydrograph at the piezometers) at the fragipan site was 1.6 days with a range of zero (no response) to 3 days. The flashiness at the paralithic contact site was 1.8 days with a range of one to three days. The average duration of the water perching as a result of the storm events, above the fragipan was 3.1 days with a range of zero to six days. At the paralithic contact site, the average duration of water perching as a result to the storm events was 7.9 days with a range of 2 days to 26 days. 
Table 3-7: Comparison of the fragipan vs. the paralithic contact soil to the nine storm events for the 2010 calendar year.

\begin{tabular}{|c|c|c|c|c|c|c|c|c|}
\hline \multirow[b]{2}{*}{ Date of precipitation } & \multicolumn{2}{|c|}{ Thickness of water at onset of event } & \multicolumn{2}{|c|}{ Peak thickness } & \multicolumn{2}{|c|}{ Time to peak } & \multicolumn{2}{|c|}{ Return to pre-event } \\
\hline & fragipan & paralithic & fragipan & paralithic & fragipan & paralithic & fragipan & paralithic \\
\hline & $\mathrm{cm}$ & $\mathrm{cm}$ & $\mathrm{cm}$ & $\mathrm{cm}$ & days & days & days & days \\
\hline 24-Jan & 17 & 34 & 25 & 44 & 1 & 1 & 2 & 2 \\
\hline 11-Mar & 22 & 38 & 26 & 47 & 2 & 2 & 3 & 5 \\
\hline 24-Apr & 0 & 0 & 22 & 29 & 2 & 3 & 5 & 7 \\
\hline 2-May & 0 & 0 & 23 & 38 & 1 & 1 & 3 & 5 \\
\hline 17-May & 3 & 0 & 8 & 10 & 1 & 1 & 1 & 2 \\
\hline 4-Nov & 0 & 1 & 0 & 5 & 0 & 1 & 0 & 4 \\
\hline 14-Nov & 0 & 0 & 12 & 22 & 3 & 3 & 5 & 26 \\
\hline $23-\mathrm{Nov}$ & 0 & 1 & 22 & 32 & 3 & 3 & 6 & 16 \\
\hline $30-\mathrm{Nov}$ & 9 & 20 & 24 & 39 & 1 & 1 & 3 & 4 \\
\hline averages----> & 5.7 & 10.4 & 18.0 & 29.6 & 1.6 & 1.8 & 3.1 & 7.9 \\
\hline
\end{tabular}

Precipitation events are $>25 \mathrm{~mm}$ cumulative rainfall periods

These data show that water perching was less on top of the fragipan, averaging 12.3 $\mathrm{cm}$ thickness attributed to the storm events compared to an average of $19.2 \mathrm{~cm}$ at the paralithic contact site. This confirms the hypothesis that the fragipan perches less water than the non-fragipan soil. Additionally, these data confirm that the fragipan perches water for shorter duration than the non-fragipan soil. The fragipan soil averages 3.1 days of perching compared to 7.9 days of perching at the non-fragipan soil, to return to pre-storm levels. This is due to the relatively low saturated hydraulic conductivity of the paralithic material. It is surmised that the time to return to pre-storm levels at the study site is a function of the underlying soils conductivity rate. And finally, these data show that the fragipan soil is flashier than the non-fragipan soil with an average time to peak of 1.6 days compared to an average of 1.8 days at the non-fragipan site. McDaniel et al. (2008) found fragipan soils with high $\mathrm{K}_{\text {sat }}$ surface layers hydrologically very flashy. The soil materials at the study site exhibit high $\mathrm{K}_{\text {sat }}$ values at the surface and low values at the fragipan and paralithic contact. The main difference is that the fragipan soil allows water to move between ped exteriors while the paralithic material lacks structure conducive to the vertical 
movement of water. Day et al. (1998) estimated that $27 \%$ of the water found at the hillslope moved vertically through the interconnected prism faces of the fragipan studied.

\subsubsection{Hypothesis $\mathrm{H}_{5}$ :}

The fifth research hypothesis involves the relationship between the thickness of water and slope aspect. The specific research hypothesis is: The thickness of water will be greater on north-facing slopes $\left(H_{5}\right)$. The results of the analysis suggest that there is no relationship between slope aspect and the thickness of water within the study watershed, disproving the research hypothesis. The monthly average thickness of water recorded at the deepest piezometers by hillslope location was used to test for aspect effect on the amount of water therein. The slope gradient at both summit locations are relatively gentle (10\% south facing and $7 \%$ north facing) and consequently incoming solar radiation strikes these locations at nearly the same angle. For this reason comparisons of those locations were not made. At the backslope locations, recorded slope gradients are steeper; $15 \%$ at Backslope (south), and 16\% at Backslope (north). The data at the backslope position, deep piezometers (Figure 3-13) reveal that the Backslope (south) is wetter (observed thickness of water is $3 \mathrm{~cm}$ to $21 \mathrm{~cm}$ greater) than the Backslope (north). 


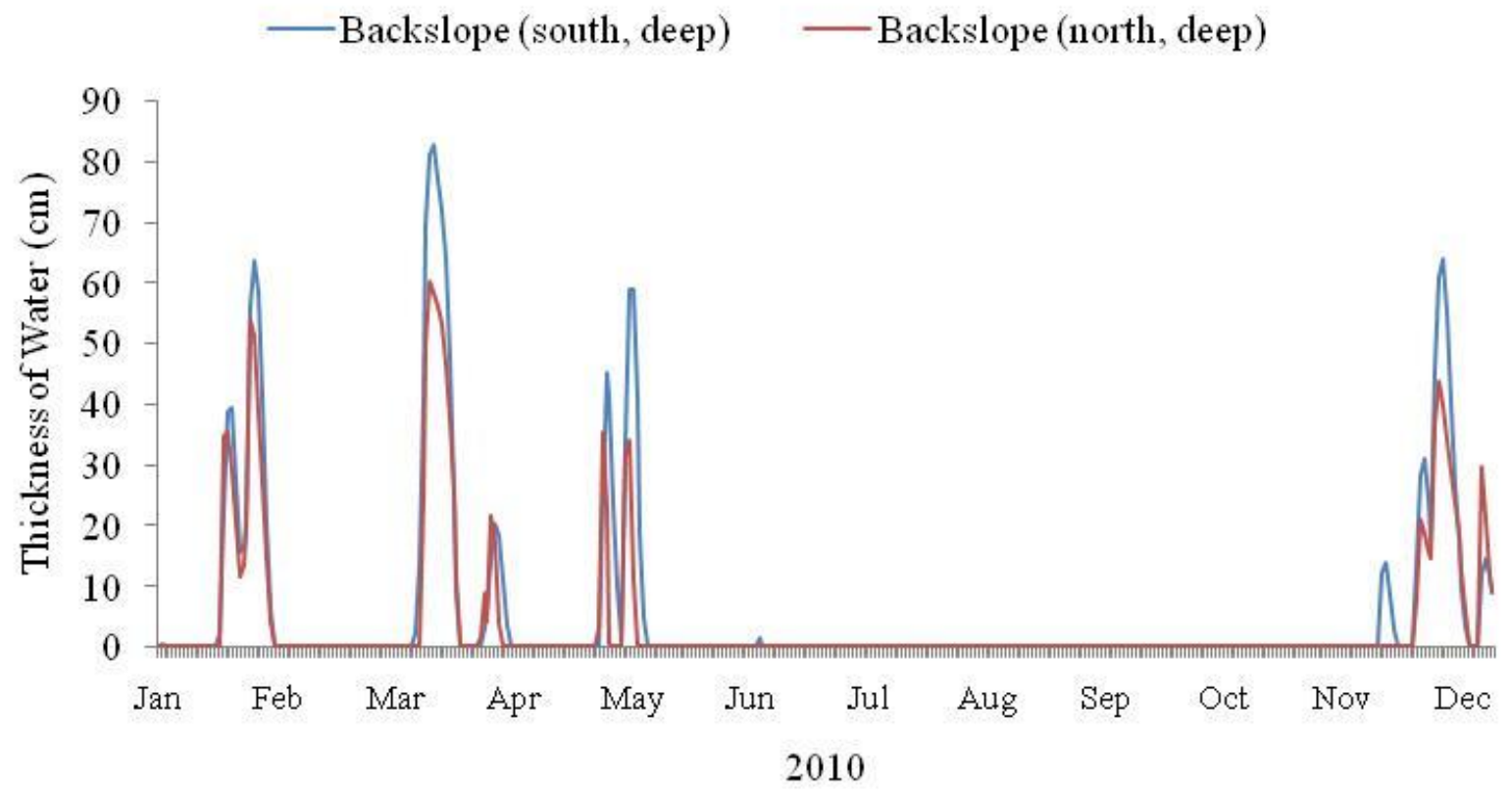

Figure 3-10: Daily average thickness of water observed in deep piezometers as measured at the backslope hillslope locations.

At the footslope locations, recorded slopes are less steep; 7\% at Footslope (south) and $10 \%$ at Footslope (north). The data at the footslope position, deep piezometers (Figure 3-11) shows that the Footslope (south) is wetter (observed thickness of water is $10 \mathrm{~cm}$ to $25 \mathrm{~cm}$ greater) than the Footslope (north) throughout the winter season and into the early summer but are drier until mid-summer when neither slope aspect registers water until the winter season returns. 


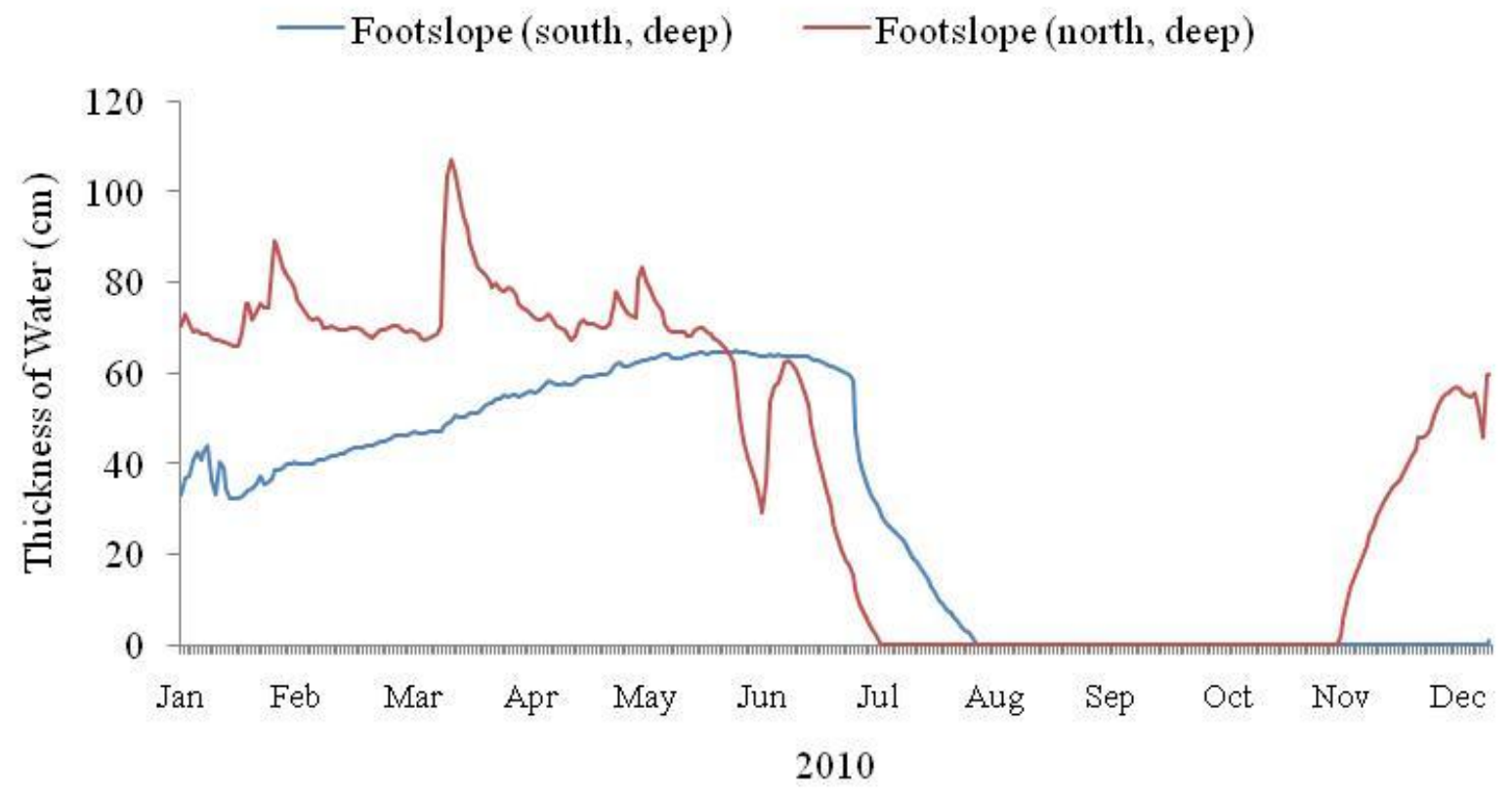

Figure 3-11: Daily average thickness of water observed in deep piezometers as measured at the footslope hillslope locations.

The comparisons of thickness of water data, show mixed results of potential slope aspect effect. At the backslope position, the Backslope (south) location shows greater thickness of water than at the Backslope (north). These results are in conflict with Carter and Ciolkosz (1991) where they found higher moisture levels on the northwest facing slopes when compared to the southwest facing. At the footslope position of the watershed, the results are inconclusive. The data show that the variation in thickness of water on this hillslope may not be due to slope aspect. It is surmised that the relatively low local relief (about 100 m elevation difference in the entire watershed) in combination with the gentle slopes throughout, do not have a significant effect on the angle of the incoming solar radiation. The research performed in this watershed is designed to address the presence of water utilizing piezometric head measurements and the connection with redoximorphic features described throughout the hillslope. The hypotheses testing herein reflect that 
connection. There are, however, other soil moisture measurements that could have been considered. Carter and Ciolkosz (1991) linked soil development differences due to northsouth aspect and attributed the differences to higher moisture levels (not necessarily saturated conditions necessary to register at a piezometer). Comparisons of percent saturation by hillslope in Hypothesis $\mathrm{H}_{2}$ (Figure 3-9) show an aspect effect utilizing the moisture content probes. From that figure, it is revealed that the Backslope (north) location is at $58 \%$ to $93 \%$ saturation (percent of total pore spaces filled with water) during the entire length of study where the Backslope (south) is at just $2 \%$ saturation during the wettest month (March 2010). A similar trend was found at the footslope locations. The Footslope (north) was at $71 \%$ to $100 \%$ saturation from June through November, 2010, while the Footslope (south) ranged from 36\% to $98 \%$ saturation during the same time period. At no time throughout the entire study period did the Footslope (south) have a higher percent saturation than the Footslope (north). The effect of slope aspect on thickness of water at this research site has not been proven. Further, Hawley et al. (1983) found little variation in topography related soil moisture which they attributed to the presence of vegetation in agricultural settings. The vegetative cover at the study site is a mature deciduous forest and the relative slope aspect differences at the canopy level are further minimized. Reid (1973) described cumulative differences in evaporative water loss between north-facing and south-facing slopes to be small but further stated that over time the small differences may have an effect on the long-term hydrologic balance. At this study site, temperature differences (section 3.6) related to slope aspect, were found. The Backslope (south) is $0.8{ }^{\circ} \mathrm{C}$ warmer than Backslope (north) and Footslope (south) is $0.5{ }^{\circ} \mathrm{C}$ 
warmer than Footslope (north). At the study site, a link between slope aspect and the thickness of water found at the piezometers has not been made.

\subsubsection{Hypothesis $\mathrm{H}_{6}$ :}

The sixth research hypothesis is related to the relationship between the thickness of water perching and season. The specific research hypothesis is: The thickness of water perching will be greater during the winter (H6). The data from the deep piezometers show a seasonal effect at all hillslope position locations (Figure 3-12). The data show a greater thickness of water in winter and early summer on all locations on the hillslope, supporting the research hypothesis. By mid-summer, water is no longer present at any hillslope position. The observed thickness of water on the hillslope is greatest at the footslope locations. At the summit, the thickness of observed water is less, but the effect of season can still be seen at both locations.

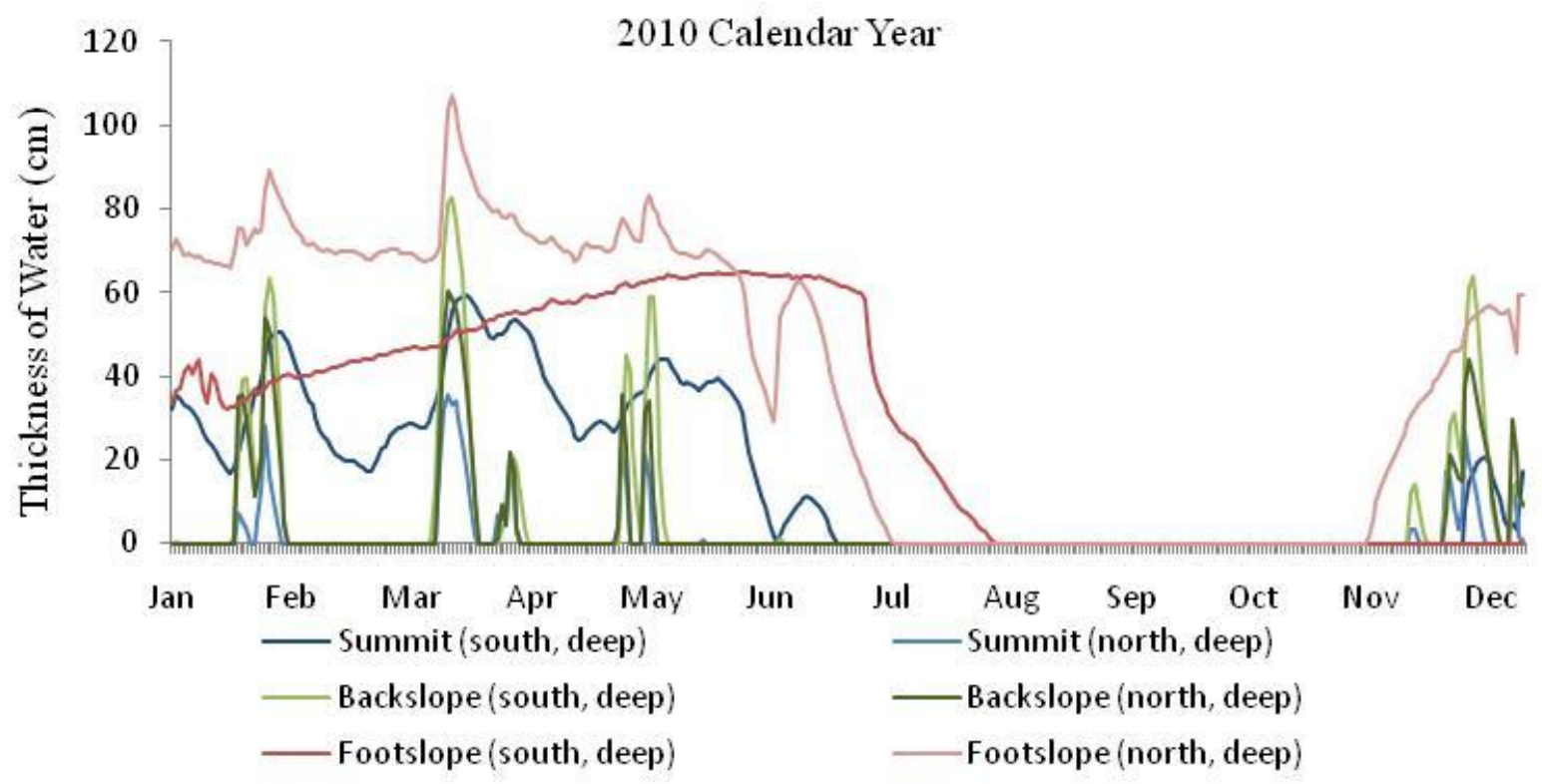

Figure 3-12: Daily average thickness of water observed in the deep piezometers as measured at all hillslope locations. 
There is less water observed at the deep piezometer at the paralithic soil location. The least amount of water observed is at the backslope locations where the last observation of water present during the 2010 calendar year, was in early May. The thickness of water observations at all locations begins again in November at the start of the winter period. When the thickness of water recorded at all deep piezometers is averaged, data results reveal for the winter period (November through April), $22.2 \mathrm{~cm}$ thickness of water perching with a maximum thickness recorded of $80.4 \mathrm{~cm}$ in March. For the summer period (May through October), results reveal an average of $8.2 \mathrm{~cm}$ thickness of water perching with a maximum thickness recorded of $69.0 \mathrm{~cm}$ in May.

The data from the shallow piezometers show a similar seasonal effect at all hillslope position locations (Figure 3-13) with the exception of backslope.

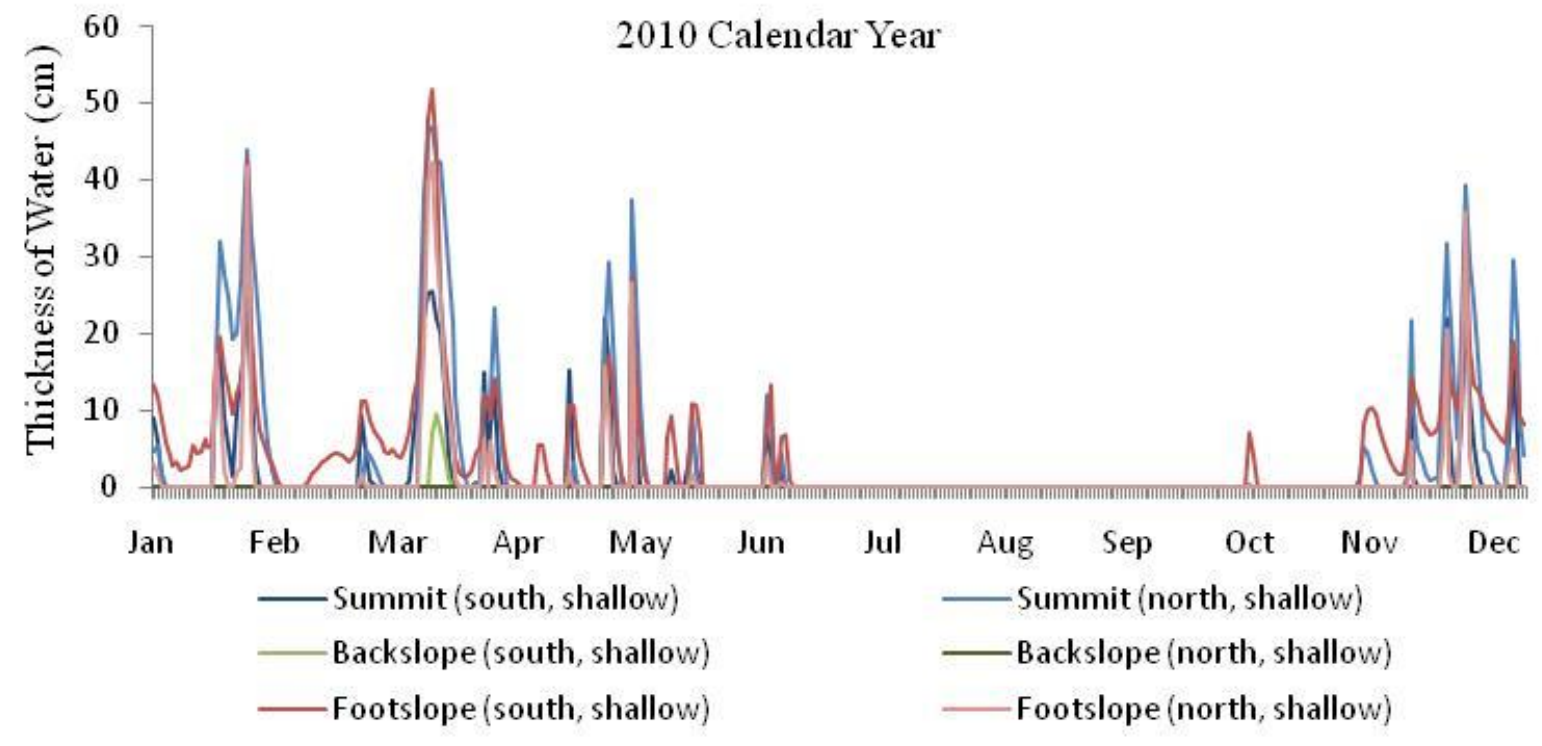

Figure 3-13: Daily average thickness of water perching above the fragipan or paralithic contact at all locations. 
The observation of water at the backslope location (mid-March) is not due to water perching on top of the fragipan but is water that has slowed moving vertically above a lower $\mathrm{K}_{\text {sat }}$ zone deeper in the soil, and is accumulating as it moves horizontally off slope (see Hypothesis $\mathrm{H}_{1}$ for further discussion).

Similar to the observations at the deep piezometers, the data show a greater thickness of water in winter and early summer at the summit and footslope positions. When the thickness of water recorded at all shallow piezometers is averaged, data results reveal for the winter period (November through April), $2.7 \mathrm{~cm}$ thickness of water perching with a maximum thickness recorded of $12.6 \mathrm{~cm}$ in December. For the summer period (May through October), results reveal an average of $0.03 \mathrm{~cm}$ thickness of water perching with a maximum thickness recorded of $1.2 \mathrm{~cm}$ in May. At the shallow piezometers however, water is no longer present at any hillslope position by mid-summer. Karathanasis et al. (2003) also found water tables nearer the surface in late winter and spring. Calmon and Day (1999) found fragipan related water tables to be absent during summer. The observed thickness of water perching on top of the fragipan zone at the summit and footslope locations is variable and no single position dominates. At the summit, water observed perching on top of the fragipan at Summit (south) is less than the observed thickness of perching on top of the paralithic contact at Summit (north). The thickness of water observations at the summit and footslope locations begins again in November at the start of the winter period. Similar results were found by McDaniel and Falen (1994) where they found the influence of fragipans on perching water to be proportionally higher during low potential evaporation periods. 
The data from the piezometers at the study site show a seasonal effect at all hillslope position locations. Similar results were reported by McDaniel et al. (2008) where they also found fragipan soils develop seasonal perched water tables.

\subsubsection{Hypothesis $\mathrm{H}_{7}$ :}

The seventh research hypothesis involves the thickness of water perching on top of the fragipan and slope curvature. Calmon and Day (1999) found fragipans on backslopes to experience greater short duration saturation events than on shoulder slopes. Famiglietti et al. (1998) reported that once the surface layer was moistened during a storm event and allowed to dry, that a correlation between curvature and percent soil moisture content became apparent. Further concluding that lateral movement was more strongly correlated to profile curvature than to plan curvature. Fujimoto et al. (2011) examined the effect of planar versus convergent hillslope types on water movement during varying rainfall events. These authors (Fujimoto et al., 2011) concluded that during low precipitation events, planar slopes continue to contribute to runoff while convergent areas retained the water on the hillslope longer. The hillslope position of backslope contains three unique slope curvatures in the plan view: linear, concave, and convex. As such, it is expected that the thickness of water perching on top of the fragipan will vary across the backslope related to slope curvature. The specific research hypothesis is: The concave position will exhibit the greatest thickness of water perching followed by the linear with the convex exhibiting the least thickness of water perching $\left(H_{7}\right)$. Results from this analysis reveal that the convergent location of concave is the wettest position. At the concave position, the data show that water is perching above the fragipan horizon for the entire period of December through May. Similar results were found by Fujimoto et al. (2011) where they 
concluded that convergent areas retained water on the hillslope longer than planar slopes. Results at the site location reveal that the divergent convex location is also wet. Data shows that water is intermittently perching above the fragipan horizon during the same period of time that the concave position is consistently saturated. Chamran et al. (2002) found concave areas to have a positive correlation to soil moisture content while convex areas exhibited a net loss in soil moisture during the same time period. Although the results of the piezometric head observations at the study site is in agreement with these earlier findings at the concave location, the results at the convex location do not align with the earlier findings. The nature of the thickness of water perching above the fragipan at the convex location is sporadic compared to the water perching at the concave location. The values of the thickness of water perching above the fragipan contact often exceed those at the concave location, but perching is shorter in duration.

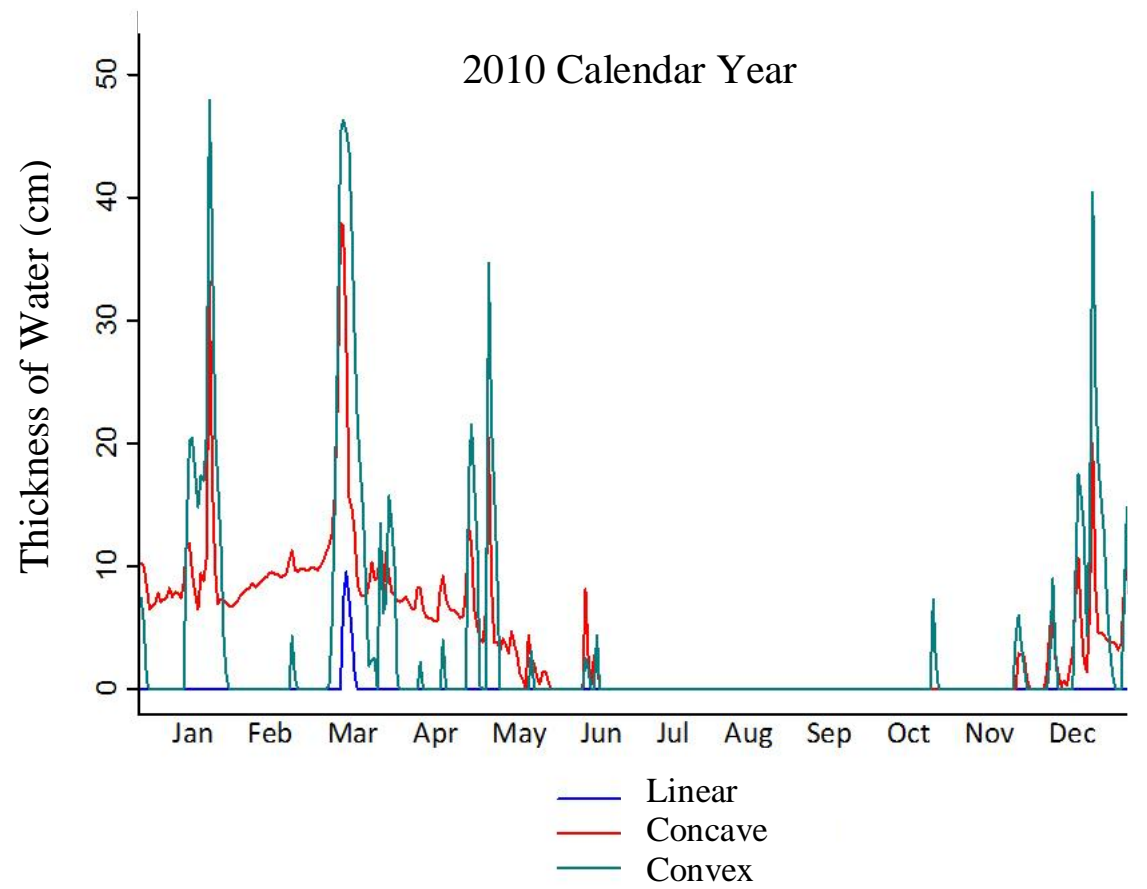

Figure 3-14: Thickness of water perching above the fragipan at slope curvature. 
The driest location is the linear position. The data shows that there is water present at the linear position for a brief period of time in March (Figure 3-17). The water at the linear location is attributed to water perching above the paralithic contact, deeper in the soil. The results of the hypothesis testing at this location are mixed. The concave location, as expected is the wettest, however, the linear location is drier than the convex. This result was not expected and nothing in the literature has resulted in these similar results. While investigating the site location, it was observed that each unique slope shape is accompanied by a correspondingly unique sub-landform. The concave location is assigned the sub-landform of swale. The convex location is assigned the sub-landform of bench. And the linear location is assigned the sub-landform of plane. These sub-landforms must be considered independently within the total backslope as the data from this research has identified widely different thicknesses of water perching above the fragipan. Interpretations derived from these data should reflect this variability.

\subsection{The Concept Model}

The concept model for the watershed is divided into two periods, summer and winter, which reflect somewhat different expectations of where the water is on the hillslope. Water is present on the hillslope during both periods but at different depths within the soil, and the thickness of which varies by hillslope position. The concept model for the watershed during the winter months (November through April) shows two separate water tables, water that is perching above the fragipan contact and water that is perching above the paralithic contact (Figure 3-15). Throughout the winter season, a shallow water table is present at both summit locations as well as at the footslope positions. The model 
depicts no water perching above the fragipan contact at the backslope, however, water is present deeper in the soil perching above the paralithic contact.

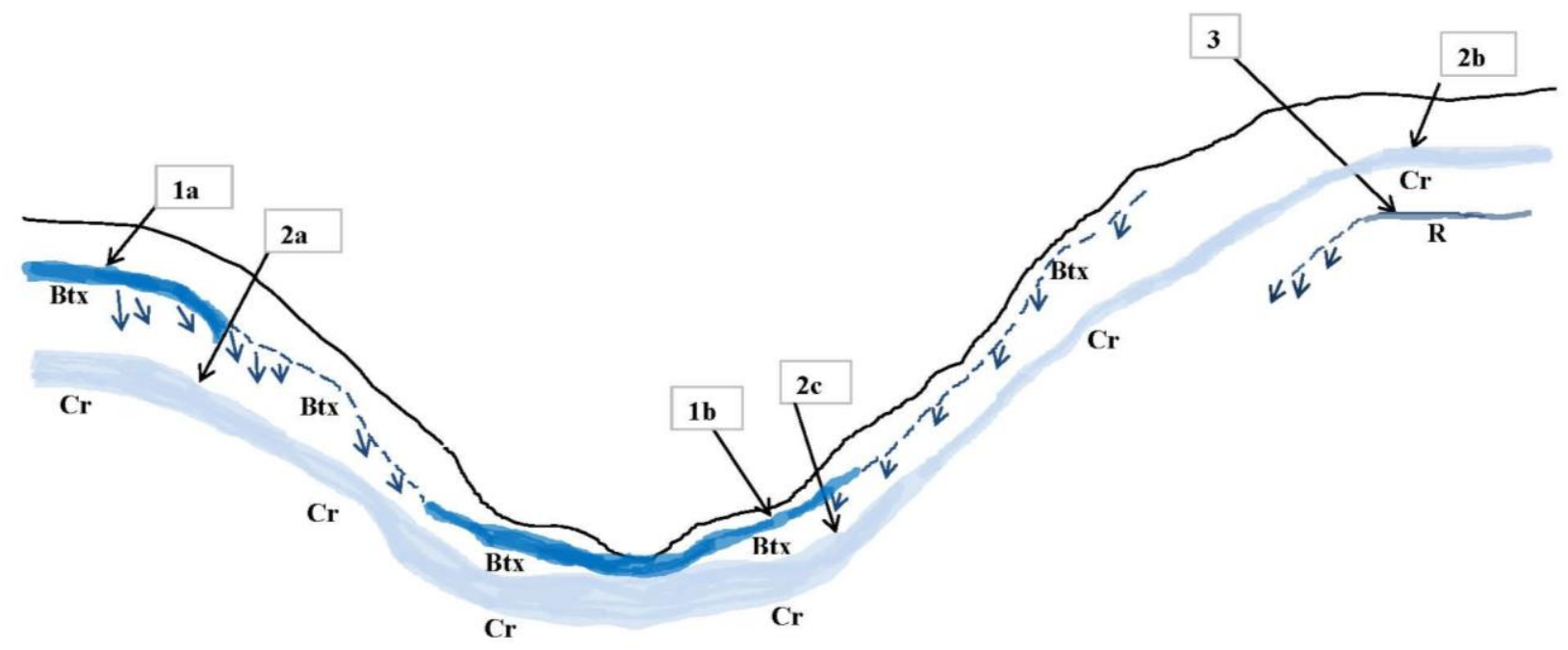

Figure 3-15: The Concept Model of water perching in winter. Depicted are two separate perching water tables. 1a-Water perched above the fragipan at the summit. 1b-Water perched above the fragipan at the footslope. 2a-Water perched above the paralithic contact beneath the fragipan at the summit. 2b- Water perched above the paralithic contact at the non-fragipan summit. 2c- Water perched above the paralithic contact beneath the fragipan at the footslope. 3- A small amount of water may be perched at the contact with the underlying bedrock.

The model suggests that water perched above the fragipan at the summit location (Figure 3-15, 1a), moves into and through the fragipan, after which the properties of the underlying paralithic contact restricts further vertical flow (Figure 3-15, 2a). At the summit location where the non-fragipan soil occurs, the paralithic contact perches water (Figure 3-15, 2b) and a small amount of water may be found at the contact with the underlying bedrock (Figure 3-15, 3). It is surmised that most of the water, moves laterally off slope above the paralithic contact. The lateral water movement is driven primarily by surface slope gradient as well as the subsurface slope gradient of the underlying stratigraphy. As the 
water reaches the backslope location, it continues to move above the paralithic contact below the fragipan layer. The fragipan layer, although perching water for a brief time (less than one day) after storm events or during peak snowmelt periods, does not move an appreciable amount of water above the contact. The wettest location on the hillslope is the footslope, at which both the fragipan (Figure 3-15, 1b) and paralithic contact (Figure 3-15, 2c) perched water table systems are most expressed. At the footslope position there is an increase in the volume of water due to the contribution from upslope areas. The concept shows both perching systems contributing to the volume flow of the stream. An observation while on site is that the water in the stream is flowing on top of the fragipan. Evidence of fragipan properties may be observed along the stream banks throughout the watershed. This leads to the conclusion that the fragipan horizon extends into the stream contributing to the overall streamflow.

The concept model for the watershed during the summer months (May through November) reveals a somewhat different scenario. During the summer season, perching water does not occur at the fragipan contact (Figure 3-16) for any appreciable length of time. Although point location results (described in earlier sections) reveal the presence of perching above the fragipan in most months, that water is transient, present sporadically, and for relatively brief periods following storm events. 


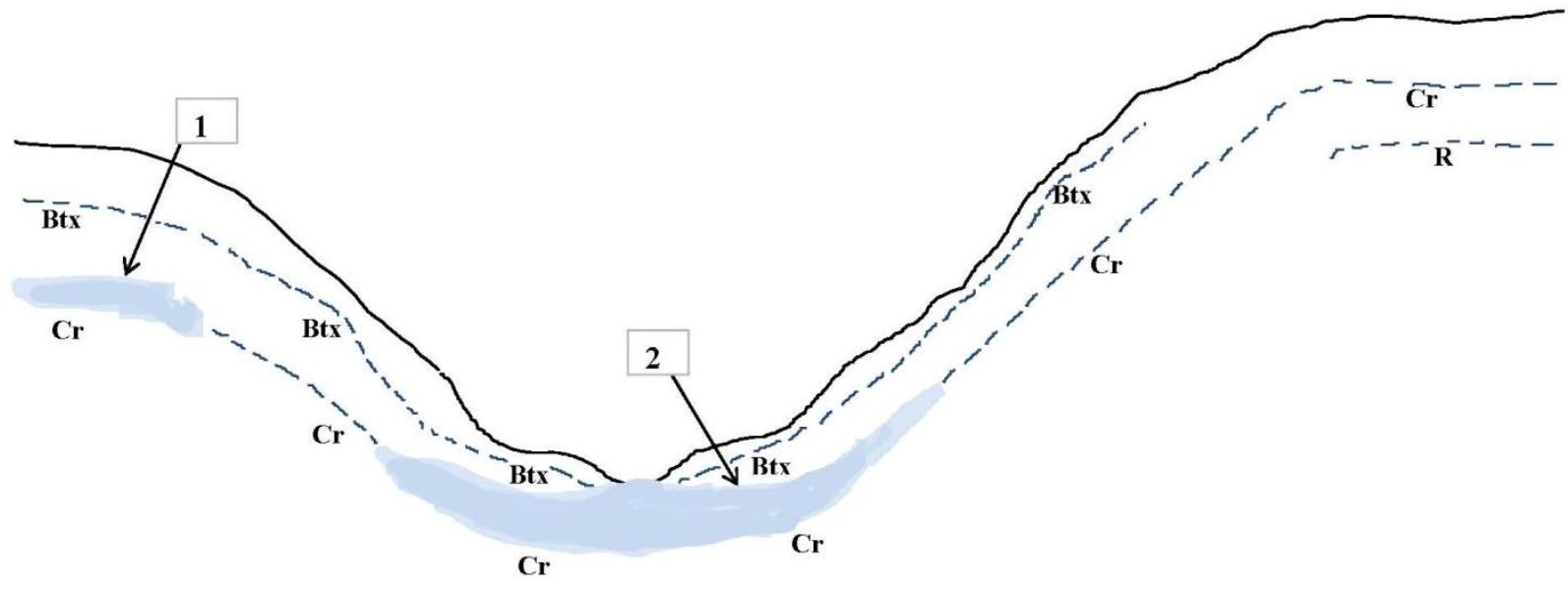

Figure 3-16: The Concept Model of water perching in summer. 1-Water perched above the paralithic contact beneath the fragipan at the summit. 2-Water perched above the paralithic contact beneath the fragipan at the footslope.

During the summer period, perching water is due to the properties of the underlying paralithic material that restricts vertical flow. Throughout the summer period, the perched water table is only present at the summit location where the fragipan soils occur.

However, the perching at these locations is beneath the fragipan at the paralithic contact (Figure 3-16, 1). At the summit location of the non-fragipan soil, no significant perching occurs. Since the summit locations are the highest in the elevation, they do not receive any upslope contribution of surface or subsurface lateral flow. The model for summer suggests that water that would have perched above the paralithic contact at the summit, has either moved laterally, driven primarily by slope gradient (surface as well as subsurface slope of the stratigraphy) or was taken up by the vegetation. Like the winter period, the concept for summer is that more water is present at the footslope positions. The wettest location on the hillslope is once again, the footslope, at which perching at the paralithic contact is well expressed (Figure 3-16,2). At the footslope position there is an increase in the volume of water due to the contribution from upslope areas. The concept of the summer period 
shows perching at the paralithic contact which alone, contributes to the volume flow of the stream. 


\section{Conclusions}

The fragipan soil at the summit (south) location classifies as fine-loamy, semiactive, mesic Typic Fragiudults. The control section from 3 to $58 \mathrm{~cm}$ has textures that range from silt loam to silty clay loam which results in a family level classification of fineloamy. A major result of the properties at this location is that these soils perch water on top of the fragipan zone during the growing season for a duration that is long enough to develop redoximorphic features above the pan. The soil moisture control section at this location is 10 to $30 \mathrm{~cm}$. Water is perching long enough during the growing season that redoximorphic features (depletions and concentrations) have developed in the zone that starts at $47 \mathrm{~cm}$ depth. The seasonal high water table during the growing season (when soil temperature is above biological zero, $5^{\circ} \mathrm{C}$ ) is at or near the same depth of redoximorphic features. The results of this analysis confirm that the soil morphology may be used to determine the depth to the seasonal high water table.

The fragipan soil at the backslope locations classify as fine, semiactive, mesic Typic Fragiudults (south) and fine-loamy, semiactive, mesic Aquic Fragiudults (north). The control section at the backslope locations are 6 to $59 \mathrm{~cm}$ at Backslope (south) and 3 to $58 \mathrm{~cm}$ at Backslope (north). The duration of water that is found perching above the fragipan at the backslope locations is less than one day. The soil moisture control section at both of these locations is 10 to $30 \mathrm{~cm}$. The water that is present at the shallow depth, causing redoximorphic features is water that has moved upward from horizons deeper in the soil profile. At the backslope (south), depletions occur in the zone that starts at $37 \mathrm{~cm}$ depth and masses and depletions are described immediately below this zone at $59 \mathrm{~cm}$ depth. At the backslope (north), masses and depletions are first described in the zone that 
starts at $33 \mathrm{~cm}$ depth (Table 3-1). The redoximorphic features above the first fragipan layer are the result of the deeper fragipan and subsequent paralithic contact further restricting downward movement, contributing to the water perching at this location. The seasonal high water table is at or near the recorded depth to redoximorphic features throughout the duration of this study. The redoximorphic features that occur at both backslope locations may partially be attributed to the perching of water on top of the first fragipan horizon as well as the contribution of water from deeper in the soil profile to shallow depths during high soil moisture times of the year.

The fragipan soil at the footslope locations classify as fine-loamy, semiactive, mesic Aquic Fragiudults (south) and fine, semiactive, mesic Aquic Fragiudults (north) respectively. The control section at the footslope locations are 6 to $52 \mathrm{~cm}$ at Footslope (south) and 3 to $65 \mathrm{~cm}$ at Footslope (north). A result of the properties at these locations is that water perches long enough during the biologically active season, at both locations, such that redoximorphic features have developed. The soil moisture control section at these locations is 10 to $30 \mathrm{~cm}$. At the Footslope (north), depletions occur in the zone that starts at $25 \mathrm{~cm}$ depth and masses and deletions are described immediately below this zone at $52 \mathrm{~cm}$ depth. At the Footslope (north), depletions occur in the zone that starts at $38 \mathrm{~cm}$ depth and masses and depletions are described immediately below this zone at $65 \mathrm{~cm}$ depth. The seasonal high water table during the biologically active season is at or near the same depth of redoximorphic features throughout the duration of this study.

The moderately deep $(50 \mathrm{~cm}$ to $100 \mathrm{~cm}$ ) soil at the Summit (north) location with a paralithic contact but no fragipan classifies as fine-loamy, semiactive, mesic Oxyaquic Hapludults. The control section from 6 to $68 \mathrm{~cm}$ has fine earth textures that range from silt 
loam to silty clay loam, which results in a family level classification of fine-loamy. Similar to fragipan soils, these soils also perch water. Similar to the restrictive layer of fragipan, these soils have a soil moisture control section that is 10 to $30 \mathrm{~cm}$. The research results presented here supports the concept of soils that perch water on top of the paralithic contact during the biologically active season, such that the development of redoximorphic features has occurred. Redoximorphic depletions are described in these soils in the zone immediately above the paralithic contact that starts at $60 \mathrm{~cm}$. The seasonal high saturation during the biologically active season, is at or near the same depth of redoximorphic features throughout the duration of this study. The results of this analysis confirm that the soil morphology may be used to determine the depth to the seasonal high water table (Morgan and Stolt, 2006; Boersma et al., 1972; Simonson and Boersma, 1972; Vepraskas et al., 1974; Veneman et al., 1976; Richardson et al., 1992; Thompson et al., 1998; Szogi and Hudnall, 1998; D’Amore et al., 2000).

At all hillslope position locations throughout this site, as saturated flow moves deeper into the soil profile under the influence of gravity, it encounters water transmissionlimiting zones. This is in part due to increasing bulk density with depth; a decrease in porosity; a decrease in structure; and other properties of the soil which contribute to decreased $\mathrm{K}_{\mathrm{sat}}$ and the reduction of the rate of vertical flow. As water continues to move into these zones, it accumulates and builds-up resulting in zones of episaturation coinciding with season. As vegetation demand during the peak of the growing season draws water out of the soil, the thickness of saturation zones decreases. As a consequence, zones of soil saturation fluctuate with the vegetative demand on a seasonal manner. Redoximorphic features expressed throughout the soil may be used to determine the depth 
to the seasonal high zones of saturation. Additionally, the effect of the first-encountered fragipan layer on the perching of water varies by hillslope position. The summit and footslope position fragipan zones perch water for significant periods of time during the biologically active season as evidenced by the redoximorphic features (Morgan and Stolt, 2006; Boersma et al., and references therein) that have developed. Duration of saturation necessary for the development of redoximorphic feature varies depending on the soil environment, and is not specified (Soil Survey Staff, 1999). Genthner et al. (1998) found a correlation between drainage class and depth to and duration of saturation. They found water tables present for 30 to 90 days in well and moderately well drained soils. Daniels et al. (1971) found soils to be saturated for $25 \%$ of the year where at horizons in the soil where redoximorphic features were described. The wettest position, as expected is the convergent area of footslope position. This is consistent with conclusions made by Sklash and Farvolden (1979) in which a groundwater "ridge" is described adjacent to streams. The main difference in the research presented here is that this observation extends the effect to a seasonal timescale rather than the post-storm event effect. As water moves down gradient by the forces of gravity both vertically through the soil profile as well as laterally from higher elevations toward lower, an accumulation occurs. This accumulating water contributes to a groundwater rise in a manner similar to the variable source area concept described in earlier research (Sklash and Farvolden, 1979; and others). At different point locations throughout the watershed, there is a contribution by adjacent areas to the groundwater at the point. It is through this concept of water movement that at lower elevation locations, there is a larger contributing area that adds to the subsequent, 
disproportionately higher rise in water table. It is through this process that the footslope location, as expected, is the wettest. The data from this research supports this concept.

The relatively thin zones of saturation at the backslope locations are credited to the decrease in bulk density with depth at the respective zones of observation. A lower bulk density of the first encountered fragipan zone when compared to deeper in the soil profile may be the explanation of why there is little perching at the contact. This phenomenon is consistent with the degradation process of the fragipan. As a pan is in the process of developing, the upper part of the horizon exhibits the most densic properties. Once fully developed, the pan then begins to degrade. Regardless of the mechanism, the degradation process is characterized by the breaking apart of the horizon. As this occurs, the structure of the horizon increases which in turn, causes the bulk density to decrease. As the pan degradation process continues, water is allowed to move more freely through the newly created macropores, via preferential flow, to the contact with the more restrictive zones below. It is proposed that this may be occurring at the study location.

Although this research was performed within West Virginia, the implications of this research apply to a much broader geographical area. The fragipan landscape model (Figures 3-15 and 3-16) consists of concepts developed using the point data from the monitoring equipment and the understanding of the link between the property-based processes on the hillslope with the observable hydrology. Patterns that emerge while using the concepts described throughout this dissertation may be used to make predictions (Tromp-van Meerveld and McDonnell, 2006) of where the water table is perching throughout the hillslope by position. As a result of this research having been performed on a benchmark soilscape, it is intended that the data collected and the associated concept 
model be utilized for the development and update of soil interpretations of fragipan landscapes. By linking processes and the resultant patterns that emerge may aid in the efficiency of decisions that surround the determination of ground-truth locations. Landscape models of benchmark soilscapes may be utilized as a soil survey update tool to enable the mapping of large areas with relatively fewer on-site observations. It is intended for this model to be used (tested and edited) while developing and revising soil map units within MLRA 127 and adjacent regions where soils with fragic properties occur as a significant percentage of the landscape. Quantifying landscapes with interpretive models is the current business model. Given the high demand for better soil interpretations and limited time for field observations, research which is designed with extrapolation to a larger geographical area in mind is essential. The need for sound research-based models is arguably more important today than at any time in the past.

Future research may consider the stage of fragipan development or degradation. This may be accomplished by opening soil pits to the top of the pan layer and carefully describing and quantifying the first encountered fragipan characteristics as described by Ciolkosz and Waltman (2000). Comparing the results of the fragipan horizons with depth will enable a thorough understanding of the prediction of future behavior of water in response to the development or degradation of the layer. The redoximorphic features present at the site are currently supported by the piezometric data. However, as the pan continues to degrade, it is feasible and most likely that the water will no longer continue to perch for significant periods of time during the growing season. At such time that this prediction occurs, the model of water movement through the landscape will convert to that 
of a bedrock controlled model in which the effect of a deep or very deep, lithic or paralithic contact will prevail.

Finally, as with any point measurement study, there is the expectation of a negative correlation between the reliability of the model with distance from the site. Testing the concept model by updating the soils map near the site will instill confidence in the performance of the model. By doing so will tell the analyst of any potential weaknesses in the model. It is anticipated that as the watershed size is increased, soil profile descriptions taken at key locations will enhance the model performance. Focusing fewer but more strategically placed observations will enhance the accuracy of the model. In this manner, as mapping is updated so too is the fragipan catena concept model. It is only through incremental enhancements that the development of the most robust model may be made. 


\section{Literature Cited}

Amoozegar, A., 1989. A compact, constant-head permeameter for measuring saturated hydraulic conductivity of the vadose zone. Soil Sci. Soc. Am. J. 53:1356-1361.

Beckman, G.G. 1984. The place of "genesis" in the classification of soils. Austral. J. Soil Res. 22:1-14.

Boersma, L., G.H. Simonson, and D.G. Watts. 1972. Soil Morphology and Water Table Relations: I. Annual Water Table Fluctuations. Soil Sci. Soc. Am. J. 36:644-648.

Buol, S.W., R.J. Southard, R.C. Graham, and P.A. McDaniel. 2003. Soil Genesis and Classification. $5^{\text {th }}$ Edition. Ames, IA, Iowa University Press.

Buol, S.W. and H. Eswaran. 2000. Oxisols. Advances in Agronomy, 68:151-195.

Bryant, R.B. 1989. Physical Processes of Fragipan Formation. Soil Science Society of America Special Publication no. 24:141-151.

Calmon, M. and R. Day. 1999. Sampling Period Intervals for Monitoring Water Tabel Dynamics in Perched Water Table Systems. Soil Science, 164(10):740-749.

Cardwell, D.H. 1975. Geologic History of West Virginia. Educational Series. Robert B. Erwin, Director and State Geologist. West Virginia Geological and Economic Survey.

Carter, B.J. and E.J. Ciolkosz. 1991. Slope gradient and aspect effects on soils developed from sandstone in Pennsylvania. Geoderma, 49:199-213.

Carvell, K. L. 1983. A Summary of 1973-1982 Weather Data from the West Virginia University Forest. W.Va. Forestry Notes No. 10.

Chamran, F., P.E. Gessler, and O.A. Chadwick, 2002. Spatially Explicit Treatment of Soil-Water Dynamics along a Semiarid Catena. Soil Sci. Soc. Am. J. 66:1571-1583.

Ciolkosz, E.J. and W.J. Waltman. 2000. Pennsylvania's Fragipans. Agronomy Series Number 147. Agronomy Department. The Pennsylvania State University, University Park, PA.

Corwin, D.L., J. Hopmans, and G.H. de Rooij. 2006. From Field- to Landscape-Scale Vadose Zone Processes: Scale Issues, Modeling, and Monitoring. Vadose Zone Journal 5:129-139. doi:10.2136/vzj2006.0004.

D’Amore, D.V., S.R. Stewart, J.H. Huddleston, and J.R. Glasmann. 2000. Stratigraphy and Hydrology of the Jackson-Fraqier Wetland, Oregon. Soil Sci. Soc. Am. J. 64:1535-1543.

Dabney, S.M. and H.M. Selim. 1987. Anisotropy of a fragipan soil: vertical vs. horizontal hydraulic conductivity. Soil Sci. Soc. Am. J. 51:3-6. 
Daniels, R.B., E.E. Gamble, and L.A. Nelson. 1971. Relations between soil morphology and water table levels on a dissected North Carolina Coastal Plain surface. Soil Science Society of America Proceedings, 35:781-784.

Day, R.L., M.A. Calmon, J.M. Stitler, J.D. Jabro, and R.L. Cunningham. 1998. Water Balance and Flow Patterns in a Fragipan Using In Situ Soil Block Design. Soil Science 167:7, 517-528.

Dingman, S.L. 2008. Physical Hydrology. $2^{\text {nd }}$ edition. Waveland Press, Inc. Long Grove, IL

Drohan, P. S. Dadio, W. Waltman, D. Lindbo, E. Ciolkosz, and S. Waltman. Testing the Unified Theory of Fragipan Genesis: Geomorphic Trends Between Fragipans, EolianAffected Soils, and Periglacial Landscapes. Soil Sci Soc. Am. Proceedings. 2009 Annual Convention, Pittsburgh, PA. Currently in review with Journal of Quaternary Research.

Duncan, M.M. and D.P. Franzmeier. 1999. Role of Free Silicon, Aluminum, and Iron in Fragipan Formation. Soil Sci. Soc. Am. J. 63:923-929.

Famiglietti, J.S., J.W. Rudnicki, and M. Rodell. 1998. Variability in surface moisture content along a hillslope transect: Rattlesnake Hill, Texas. Journal of Hydrology, 210:259-281.

Ford, C.R., and J.M. Vose. 2007. Tsuga Canadensis (L.) Carr. Mortality Will Impact Hydrologic Process in Southern Appalachian Forest Ecosystems. Ecological Applications, 17(4):1156-1167.

Fujimoto, M., N. Ohte, and M. Tani, 2011. Effects of hillsope topography on runoff response in a small catchment in the Fudoji Experimental Watershed, central Japan. Hydrological Processes. DOI: 10.1002/hyp.7943.

Gburek, W.J., B.A. Needelman, and M.S. Srinivasan. 2006. Fragipan controls on runoff generation: Hydropedological implications at landscape and watershed scales. Geoderma, 131:330-344. doi:10.1016/j.geoderma.2005.03.021

Genthner, M.H., W.L. Daniels, R.L. Hodges, and P.J. Thomas. 1998. Redoximorphic Featues and Seasonal Water Table Relations, Upper Coastal Plain, Virginia. Soil Sci. Soc. Am. J. 54:43-60.

Gerrard, J. 1993. Soil Geomorphology - Present dilemmas and future challenges. Geomorphology, 7:61-84.

Glazovskaya, M.A., 1972. Soils of the World. Volume I. Soil Families and Soil Types. Moscow University Publishers. Published for the United States Department of Agriculture, and the National Science Foundation, Washington, D.C., by Amerind Publishing Co. Pvt. Ltd., New Delhi. 1983.

Grossman, R.B. and F.J. Carlisle. 1969. Fragipan Soils of the Eastern United States. Advances in Agronomy Journal, 21:237-279. 
Grossman, R.B., F. Stephen, J.B. Fehrenbacher, and A.H. Beavers. 1959. Fragipan Soils of Illinois:III, Micromorphological studies of the Hosmer silt loam. Soil Science Society of America Proceedings, 23:73-75.

Hall, G.F., 1983. Pedology and geomorphology. Pedogenesis and Soil Taxonomy, I. Concepts and Interactions, Wilding, L.P., N.E. Smeck, and G.F. Hall (Eds.), Elsevier, Amsterdam, pp.117-140.

Hare, C.E., 1957. Geology of Coopers Rock State Forest and Mont Chateau State Park. State Park Bulletin No.5. Paul H. Price, Director and State Geologist. West Virginia Geological and Economic Survey. 26 p, 14 pl, 3 f.

Hawley, M.E., T.J. Jackson, and R.H. McCuen. 1983. Surface Soil Moisture Variation on Small Agricultural Watersheds. Journal of Hydrology, 62:179-200.

Heald, W.R. and A.S. Rogowski. 1977. Soil Water Movement in a Sloping Fragipan System. Watershed Research in eastern North America; a workshop to compare results. 279:919, 385-399.

Hole, F.D. 1978. An approach to landscape analysis with emphasis on soils. Geoderma, $21: 1-23$

Jacobs, P.M., L.T. West, and J.N. Shaw. 2002. Redoximorphic Features as Indicators of Seasonal Saturation, Lowndes County, Georgia. Soil Sci. Soc. Am. J. 27:212-215.

Jenny, H. 1941. Factors of Soil Formation: A System of Quantitative Pedology. McGrawHill, New York.

Johnson, W.M., 1963. The pedon and the polypedon. Soil Sci. Soc. Am. Proc. 27:212-215.

Karathanasis, A.D., 1987. Mineral Solubility Relationships in Fragiudalfs of Western Kentucky. Soil Sci. Soc. Am. J. 51:475-481.

Keim R.F., A.E. Skaugset, and M. Weiler. 2006. Storage of water on vegetation under simulated rainfall of varying intensity. Advances in Water Resources, 29:974-986. DOI:10.1016/j.advwatres.2005.07.017.

Lagacherie, P., J.M. Robbez-Masson, N. Nguyen-The, and J.P. Barthes, 2001. Mapping of reference area representativity using a mathematical soilscape distance. Geoderma 101:105-118.

Lin, H.S. 2010. Linking principles of soil formation and flow regimes. Journal of Hydrology, 393:3-19. DOI:10.1016/j.jhydrol.2010.02.013.

Lin, H.S. 2003. Hydropedology: bridging disciplines, scales, and data. Vadose Zone Journal 2:1-11.

Lin, H.S., J. Bouma, Y. Pachepsky, A. Western, J. Thompson, R. van Genuchten, H-J Vogel, and A. Lilly. 2006. Hydropedology: Synergistic integration of pedology and hydrology. Water Resources Research, 42:W05301, doi:10.1029/2005WR004085. 
Lin, H.S., W. Kogelmann, C. Walker, and M.A. Bruns. 2006. Soil moisture patterns in a forested catchment: A hydropedological perspective. Geoderma, 131:345-368. DOI:10.1016/j.geoderma.2005.03.013.

Lindbo, D.L., F.E. Rhoton, J.M. Bigham, W.H. Hudnall, F.S. Jones, N.E. Smeck, and D.D. Tyler. 1995. Loess Toposequences in the Lower Mississippi River Valley: I. Fragipan Morphology and Identification. Soil Sci. Soc. Am. J. 59:487-500.

Lindbo, D.L., F.E. Rhoton, W.H. Hudnall, N.E. Smeck, J.M. Bighan, and D.D. Tyler. 2000. Fragipan Degradation and Nodule Formation in Glossic Fragiudalfs of the Lower Mississippi River Valley. Soil Sci. Soc. Am. J. 64:1713-1722.

McDaniel, P.A. and A.L. Falen. 1994. Temporal and spatial patterns of episaturation in a fragixeralf landscape. Soil Sci. Soc. Am. J. 58(5):1451-1457.

McDaniel, P.A., R.W. Gabehart, A.L. Falen, J.E. Hammel, and R.J. Reuter. 2001. Perched Water Tables on Argixeroll and Fragixeralf Hillslopes. Soil Sci. Soc. Am. J. 65:805-810.

McDaniel, P.A., M.P. Regan, E. Brooks, J. Boll, S. Barndt, A. Falen, S.K. Young, J.E. Hammel, 2008. Linking fragipans, perched water tables, and catchment-scale hydrological processes. Catena, 73:166-173 DOI: 10.1016/j.catena.2007.05.011

Miller, F.P., N. Holowaychuk, and L.P. Wilding. 1971. Canfield silt loam, a Fragiudalf: I. Macromorphological, physical, and chemical properties. Soil Science Society of America Proceedings, 35:319-324.

Moore, R.D. 2005. Slug Injection Using Salt in Solution. Streamline Watershed Management Bulletin. 8:2.

Morgan, C.P. and M.H. Stolt. 2006. Soil Morphology-Water Table Cumulative Duration Relationships in Southern New England. Soil Sci. Soc. Am. J. 70:816-824.

Norfleet, M.L., 1992. The relationship of fragipan strength and expression to the morphology, mineralogy, and soil solution composition of fragipan soils of Kentucky. Ph.D. Dissertation, University of Kentucky.

Parlange, M.B., T.S. Steenhuis, D.J. Timlin, F. Stagnitti, and R.B. Bryant. 1989. Subsurface Flow Above a Fragipan Horizon. Soil Science 148:2, 77-86.

Payton, R.W. 1992. Fragipan formation in argillic brown earths (Fragiudalfs) of the Milfield, north-east England. I. Evidence for a periglacial stage of development. Journal of Soil Science 43:621-644.

Reid, I. 1973. The Influence of Slope Orientation Upon the Soil Moisture Regime, and its Hydrogeomorphological Significance. Journal of Hydrology, 19:309-321.

Richardson. J.L., L.P. Widing, and R.B. Daniels. 1992. Recharge and discharge of groundwater in aquic conditions illustrated with flownet analysis. Geoderma 53:65-78. 
Roton, F.E. and M.J.M. Romkens. 1998. Water Distribution in a Fragipan Soil During the Growing Season. Agronomy Journal. 90:368-375.

Rowe, P.B. 1963. Streamflow Increases After Removing Woodland-Riparian Vegetation From a Southern California Watershed. Journal of Forestry, 61(5):365-370.

Ruhe, R.V., 1975. Geomorphology: Geomorphic Processes and Surficial Geology. Houghton Mifflin Company, Boston.

Scalenghe, R., G. Certini, G. Corti, E. Zanini, and F.C. Ugolini. 2004. Segregated Ice and Liquefaction Effects on Compaction of Fragipans. Soil Sci. Soc. Am. J. 68:204-214.

Schaetzl, R., and S. Anderson. 2005. Soils: Genesis and Geomorphology. Cambridge University Press, UK.

Schoeneberger, P.J., and D.A. Wysocki, E.C. Benham, and W.D. Broderson (editors), 2002. Field book for describing and sampling soils, Version 2.0. Natural Resources Conservation Service, National Soil Survey Center, Lincoln, NE.

Simonson, G.H. and L. Boersma. 1972. Soil Morphology and Water Table Relations: II. Correlation Between Annual Water Table Fluctuations and Profile Features. Soil Sci. Soc. Am. Proc. 36:649-653

Sklash, M.G. and R.N. Farvolden. 1979. The Role of Groundwater in Storm Runoff. Journal of Hydrology. 43:45-65.

Soil Survey Division Staff. 1993. Soil Survey Manual. United States Department of Agriculture Handbook No. 18.

Soil Survey Staff. 1999. Soil Taxonomy, $2^{\text {nd }}$ edition. United States Department of Agriculture, Natural Resources Conservation Service.

Soil Survey Staff. 2010. Keys to Soil Taxonomy, eleventh edition. United States Department of Agriculture, Natural Resources Conservation Service.

Soil Survey Staff, Natural Resources Conservation Service, United States Department of Agriculture. Official Soil Series Descriptions [Online WWW]. Available URL: http://soils.usda.gov/technical/classification/osd/index.html [accessed 10 February 2008]. USDA-NRCS, Lincoln, NE.

Soil Survey Staff, Natural Resources Conservation Service, United States Department of Agriculture. Soil Survey of Marion and Monongalia County, West Virginia [Online WWW \} at http://soildatamart.nrcs.usda.gov/Survey.aspx ?State=WV [Accessed 10 September 2008].

Soil Survey Laboratory Staff. 2004. Soil survey laboratory methods manual. USDA-NRCS Soil Survey Investigations Report No. 42. U.S. Govt. Print. Office, Washington, DC.

Sprecher, S.W. 2008. Installing monitoring wells in soils (Version 1.0). National Soil Survey Center, Natural Resources Conservation Service, USDA, Lincoln, NE. 
Stolt, M.H., M.H. Genthner, W.L. Daniels, V.A. Groover, and S. Nagle. 1998. Quantifying Iron, Manganese, and Carbon Fluxes in Near-Surface Horizons of Palustrine Wetlands. Soil Sci. Soc. Am. J. 54:25-42.

Szogi, A.A. and W.H. Hudnall. 1998. Soil Morphology and Frequency of Diagnostic Wet Soil Conditions. Soil Sci. Soc. Am. J. 54:61-76.

Thompson, J.A., J.C. Bell, and C.W. Zanner. 1998. Hydrology and Hydric Soil Extent with a Mollisol Catena in Southeastern Minnesota. Soil Science Society of America Journal. 62:1126-1133.

Tromp-van Meerveld, H.J. and J.J. McDonnell. 2006. Threshold relations in subsurface stromflow:2. The fill and spill hypothesis. Water Resources Research. Vol.42. W02411. doi:10.1029/2004WR003800.

United States Department of Agriculture, Natural Resources Conservation Service. 2006. Land Resource Regions and Major Land Resource Areas of the United States, the Caribbean, and the Pacific Basin. U.S. Department of Agriculture Handbook 296.

U.S. Department of Agriculture, Natural Resources Conservation Service, 2007. National Soil Survey Handbook, title 430-VI. [Online] Available:

http://soils.usda.gov/technical/handbook/

Veneman, P.L.M., M.J. Vepraskas, and J. Bouma. 1976. The Physical Significance of Soil Mottling in a Wisconsin Toposequence. Geoderma 15:103-118.

Vepraskas, M.J., M.G. Baker, and J. Bouma. 1974. Soil Mottling and Drainage in a Mollic Hapludalf as related to Suitability for Septic Tank Construction. Soil Sci. Soc. Am. J. 38:497-501.

Weisenborn, B.N. and R.J. Schaetzl. 2005. Range of Fragipan Expression in Some Michigan Soils: I. Morphological, Micromorphological, and Pedogenic Characterization. Soil Science Sci. Am. J. 69:168-177.

Wilding, L.P. and H. Lin. 2006. Advancing the frontiers of soil science towards a geosciences. Geoderma 131:257-274.

Wilding, L.P. 2000. Pedology. Handbook of Soil Science. M.E. Sumner, editor. Pp. E1-E4. CRC Press, Boca Raton, FL 


\section{Appendix}

\subsection{NSSL Results}

\subsubsection{NSSL Site Summit (south)}

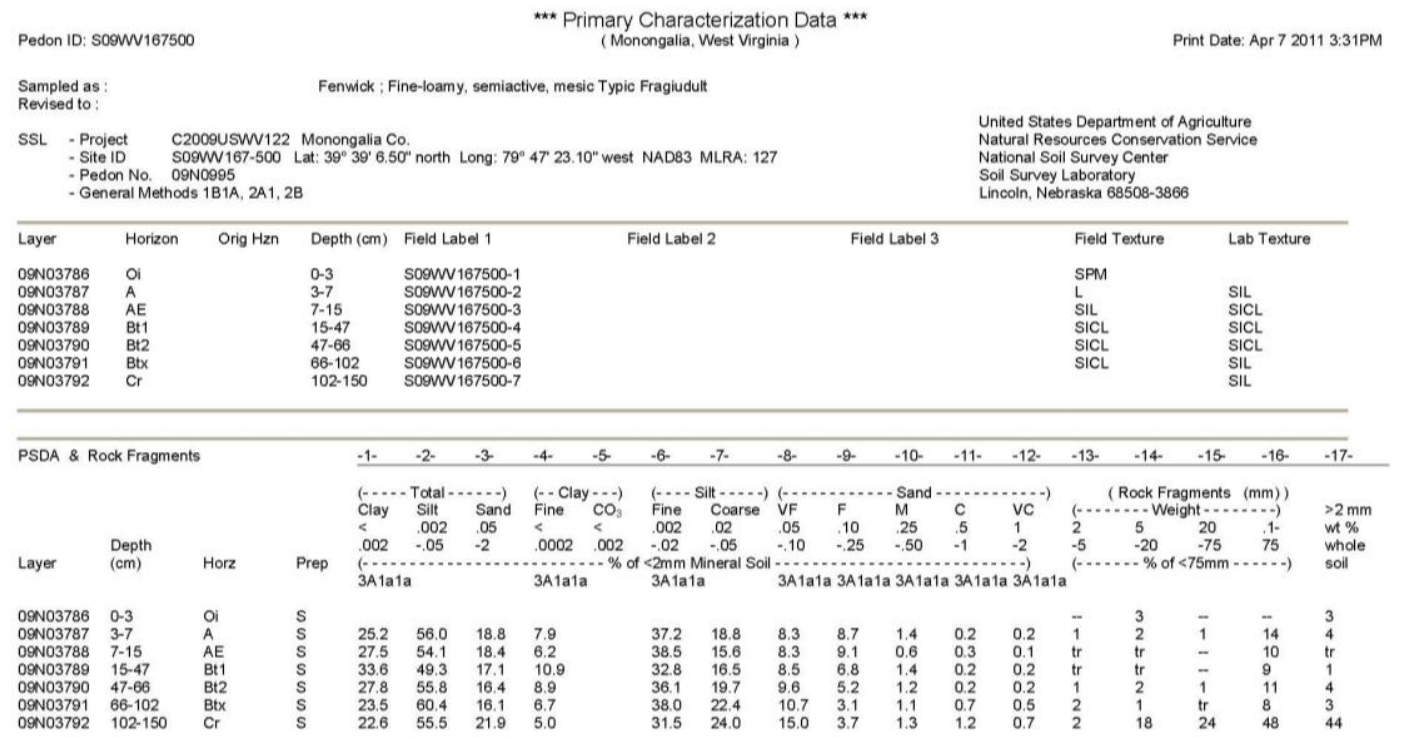

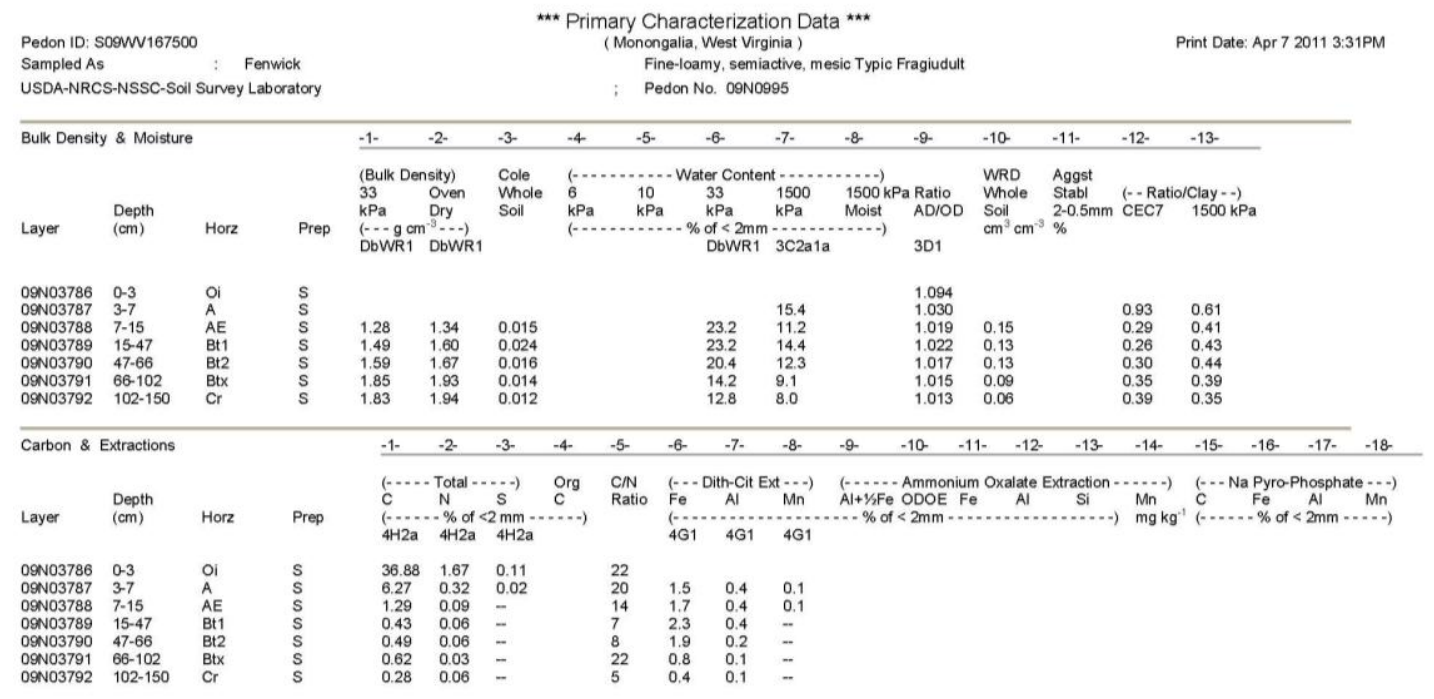




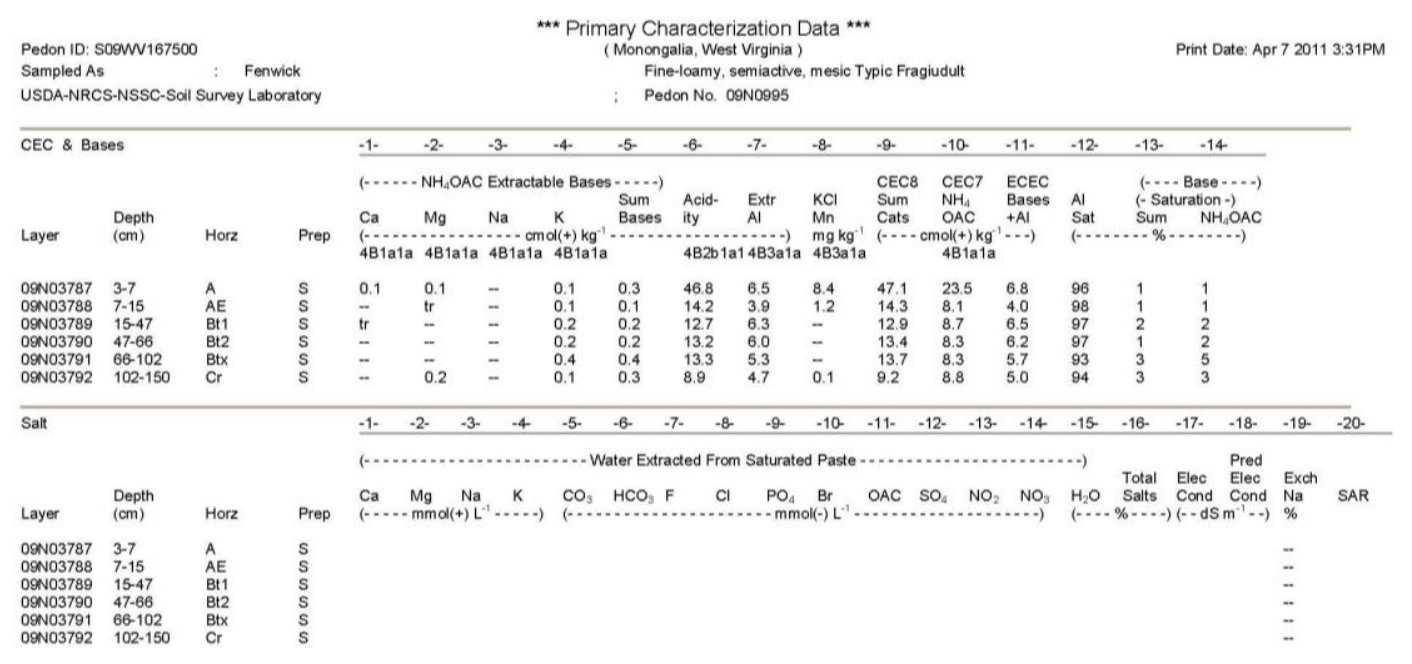

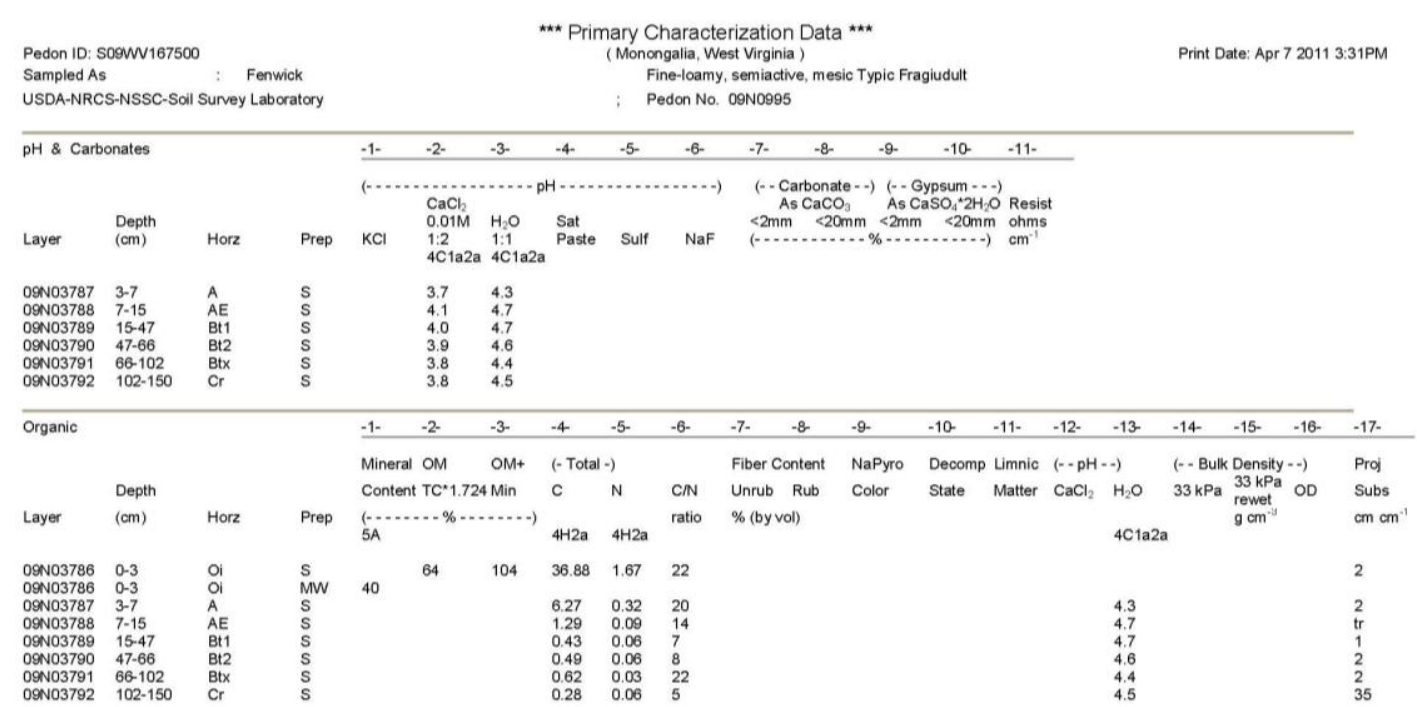

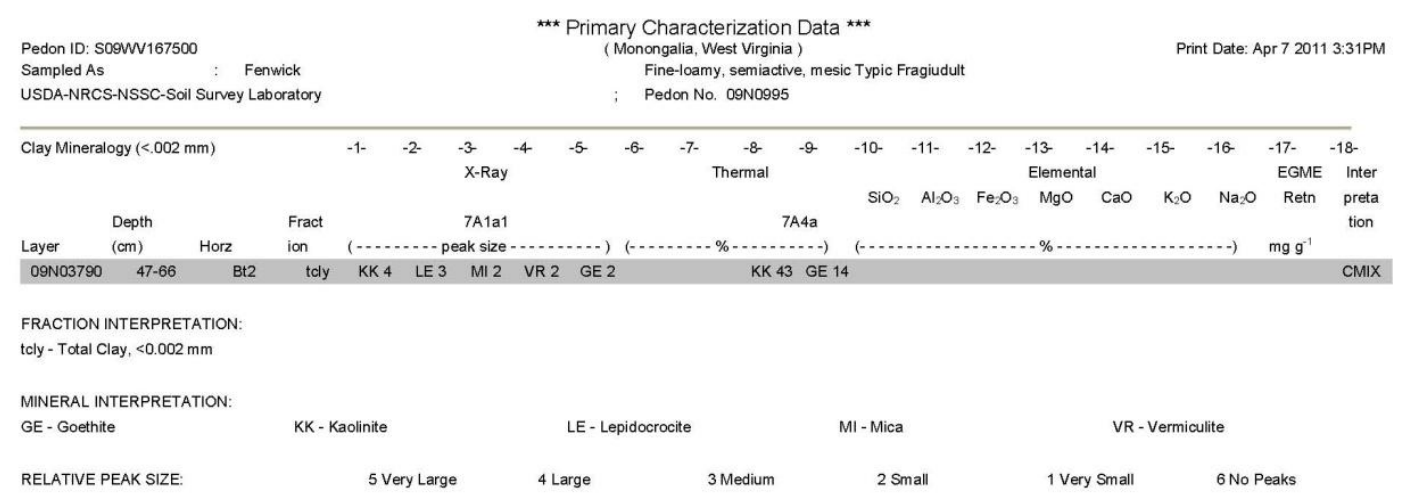




\subsubsection{NSSL Site Backslope (south)}

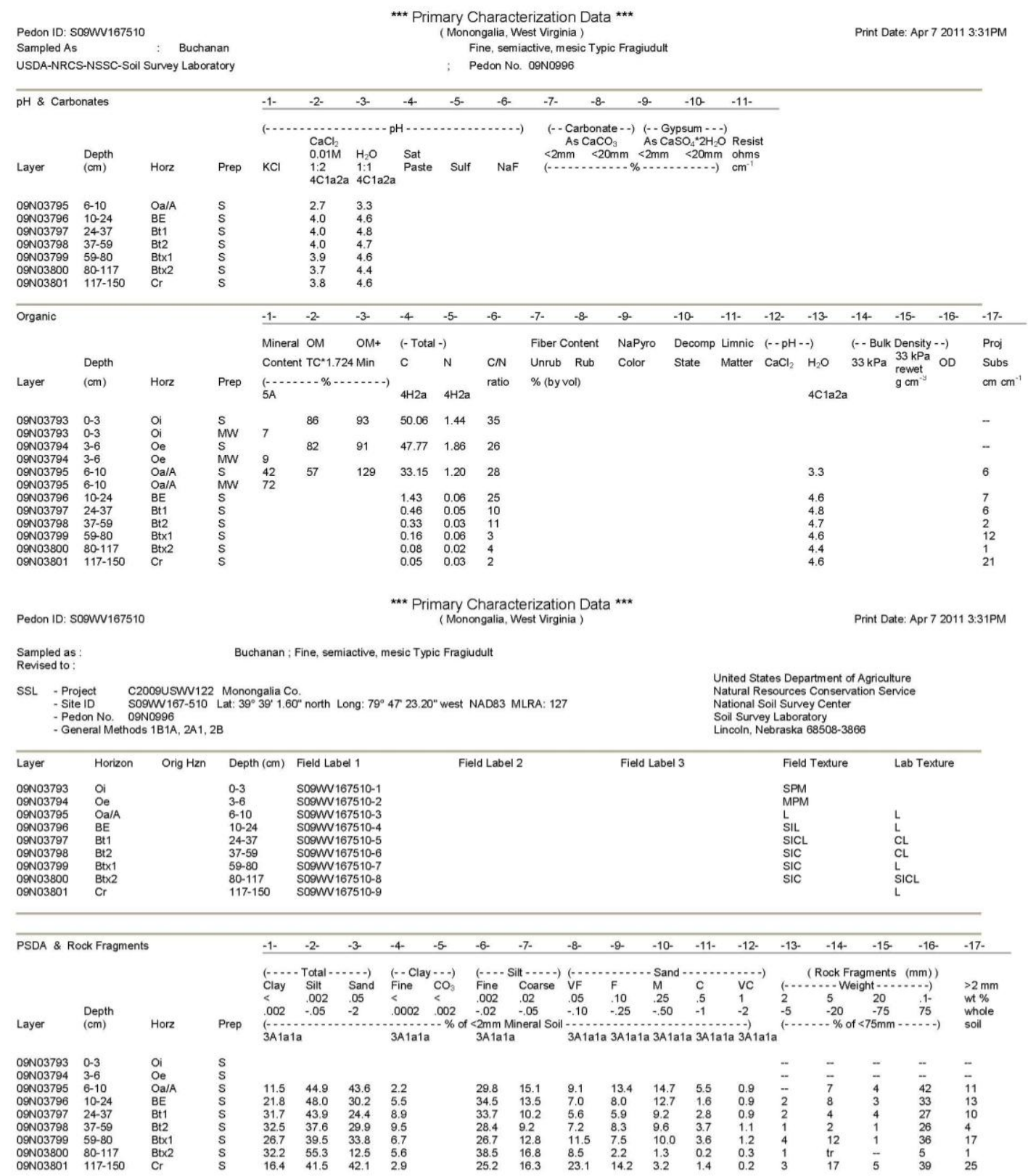




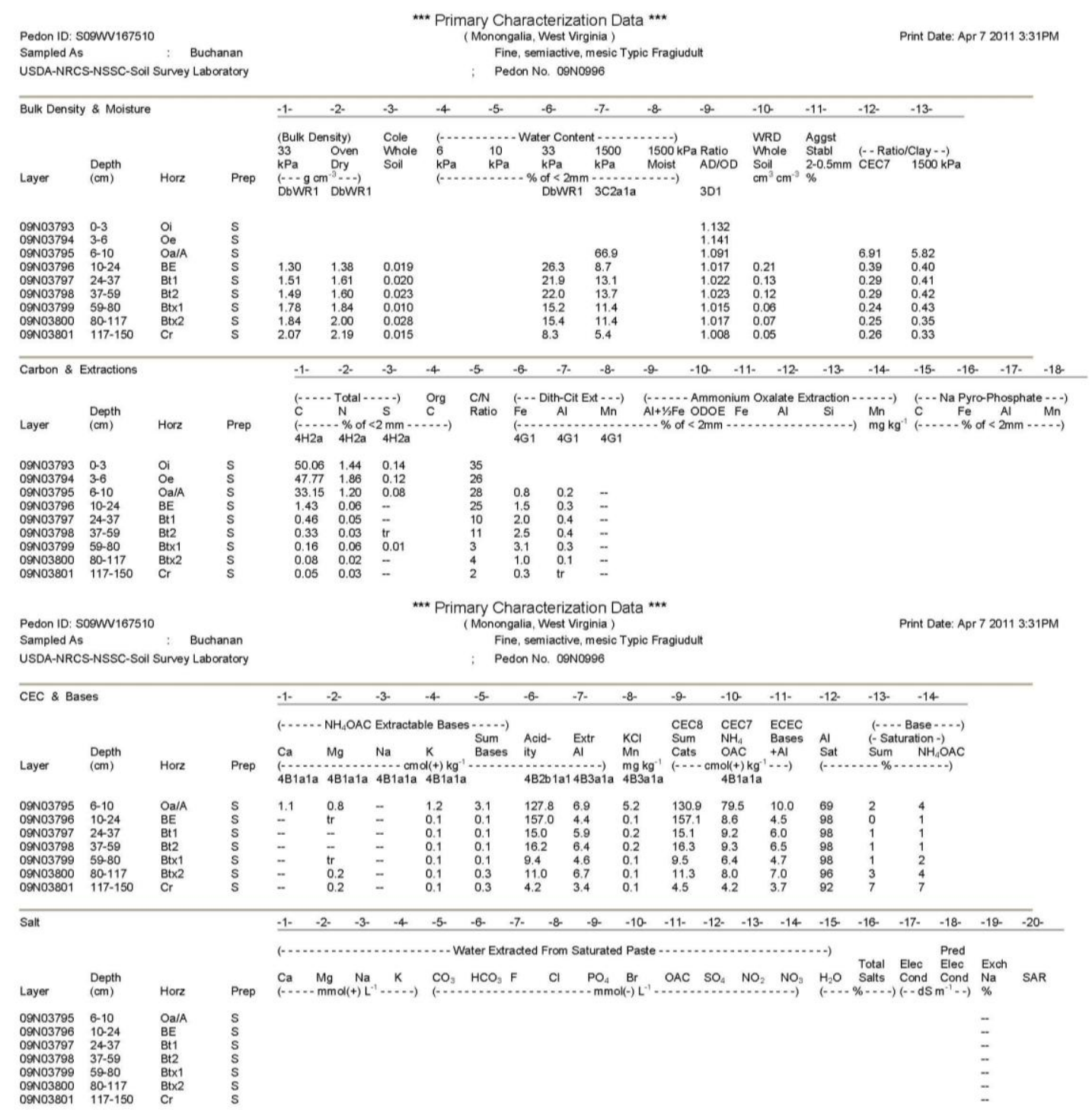




\subsubsection{NSSL Site Footslope (south)}

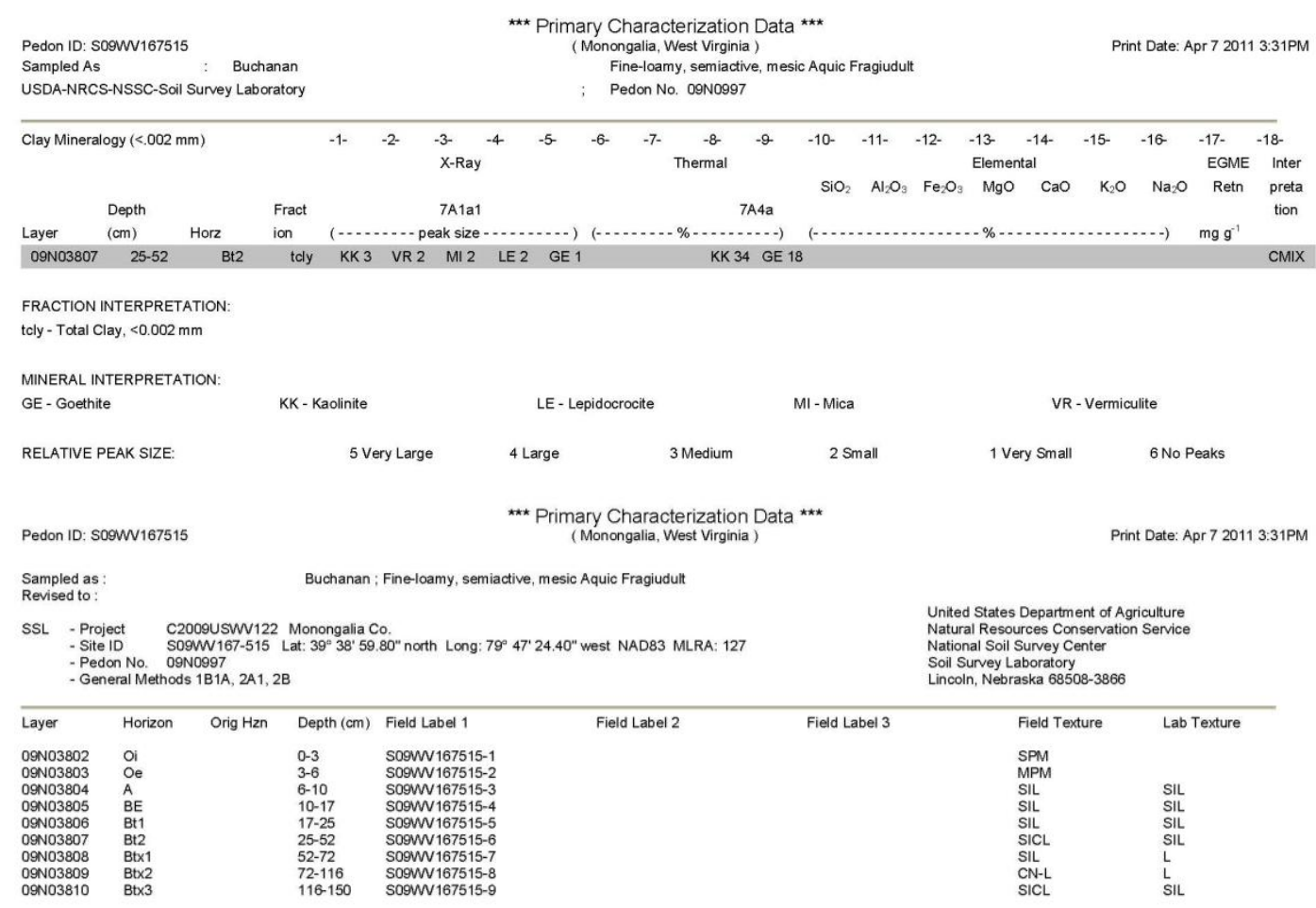

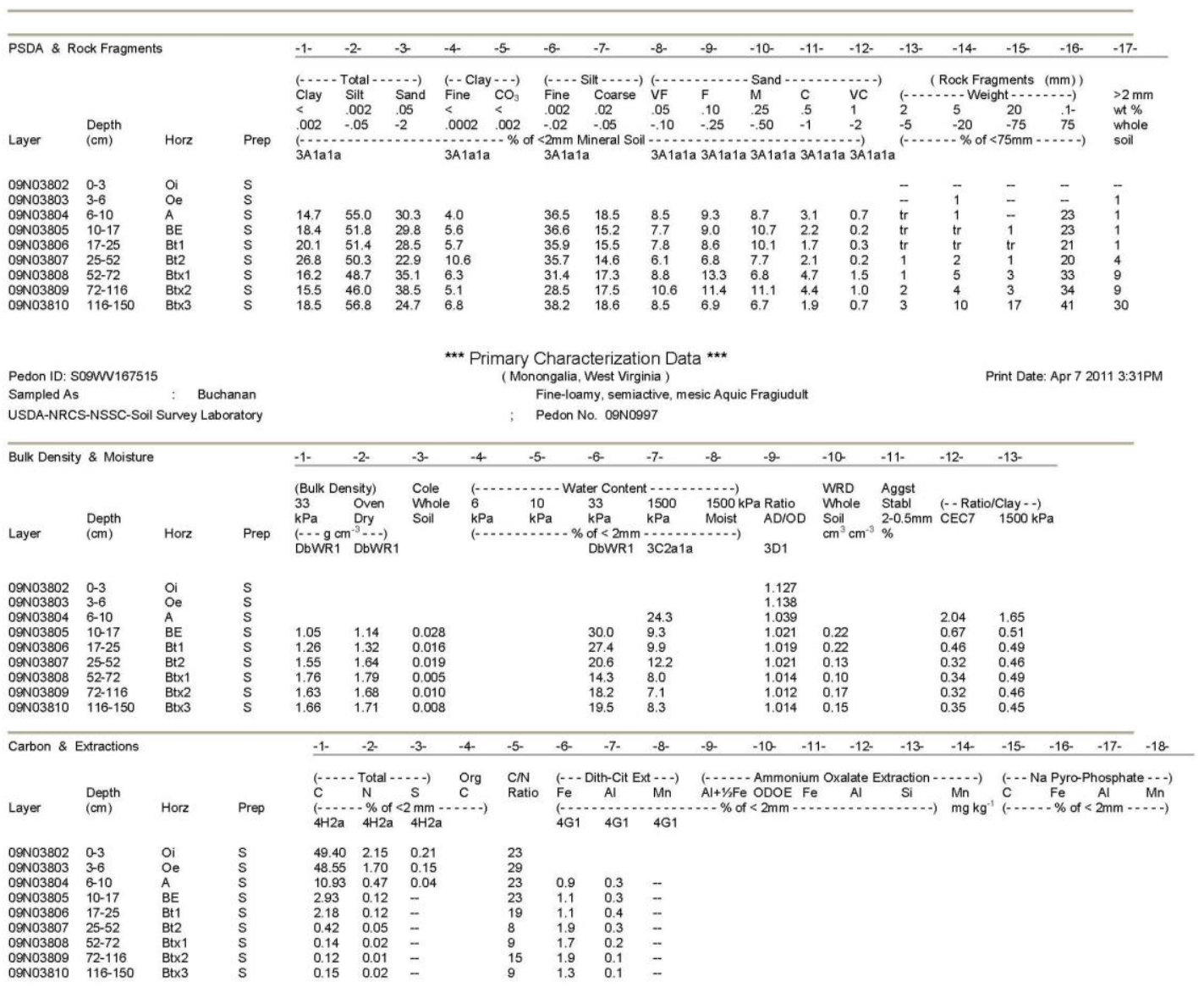




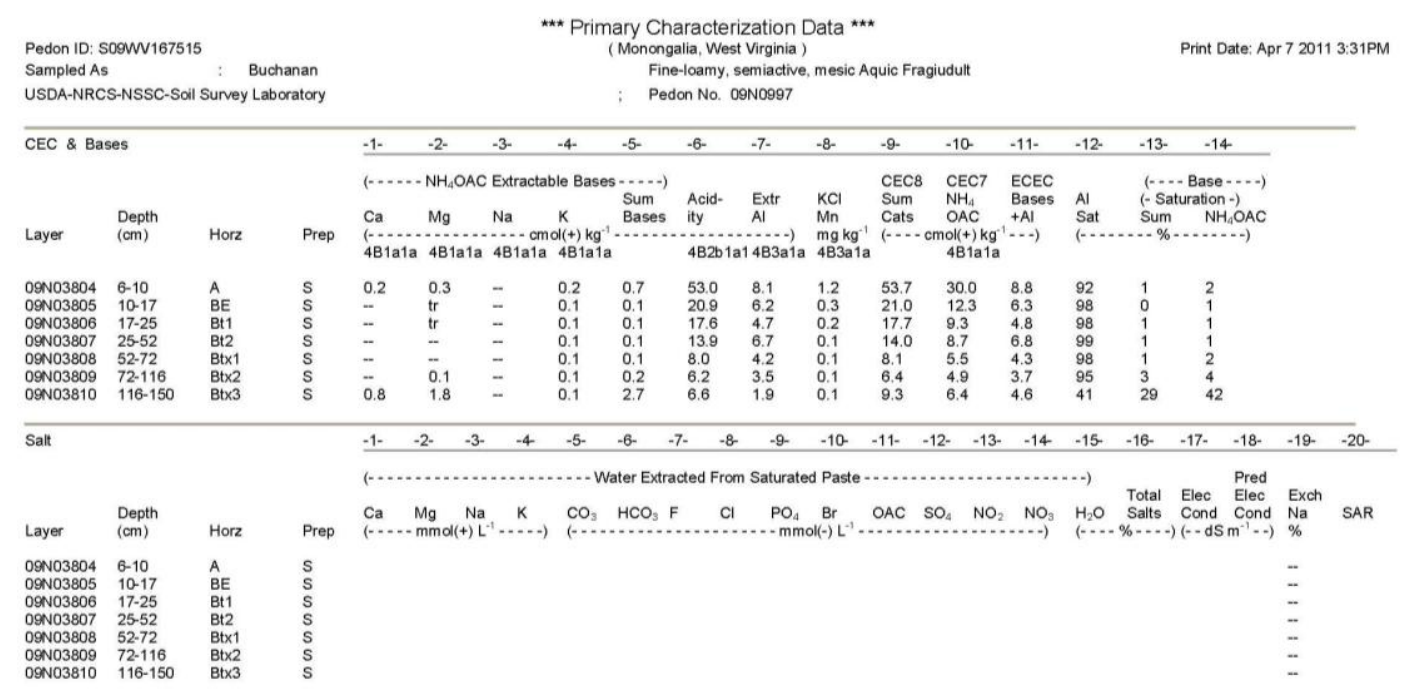

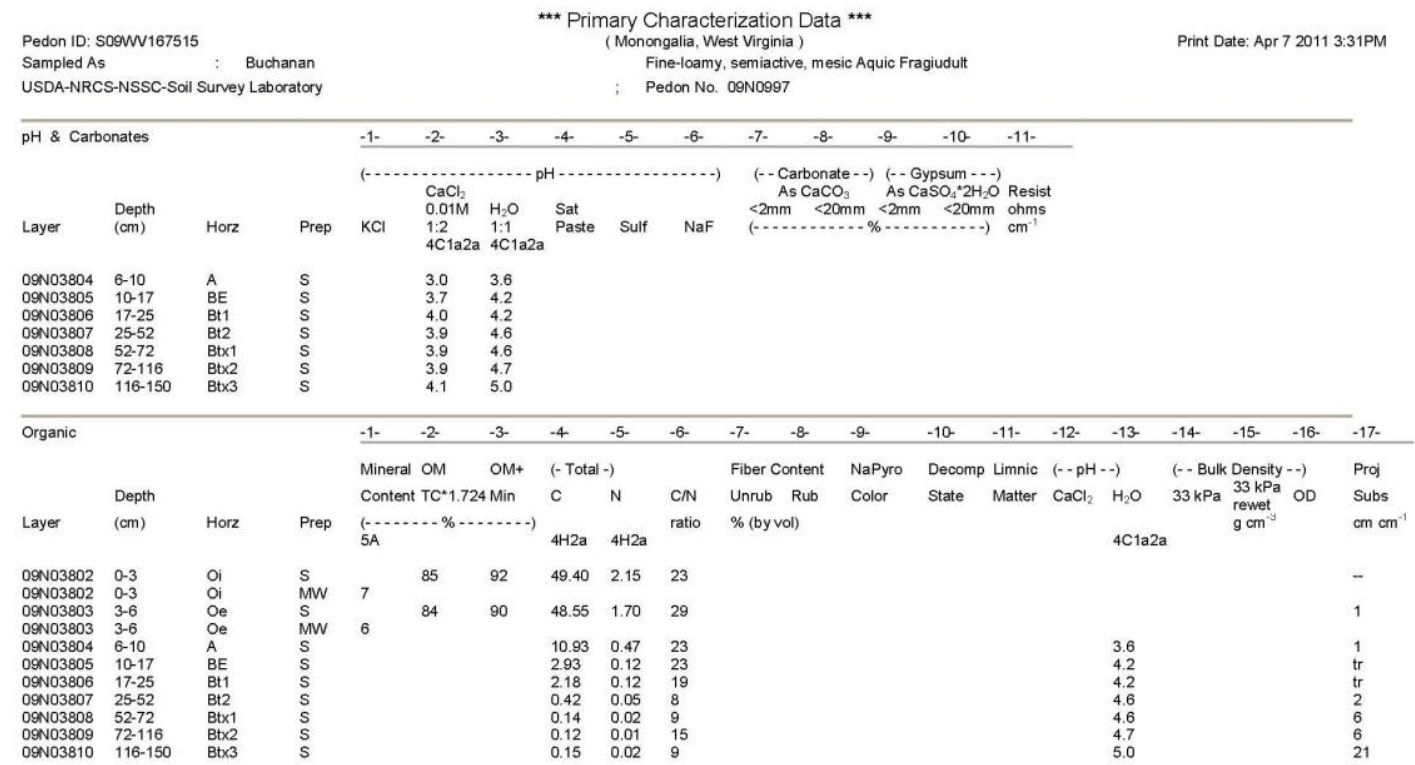




\subsubsection{NSSL Site Footslope (north)}

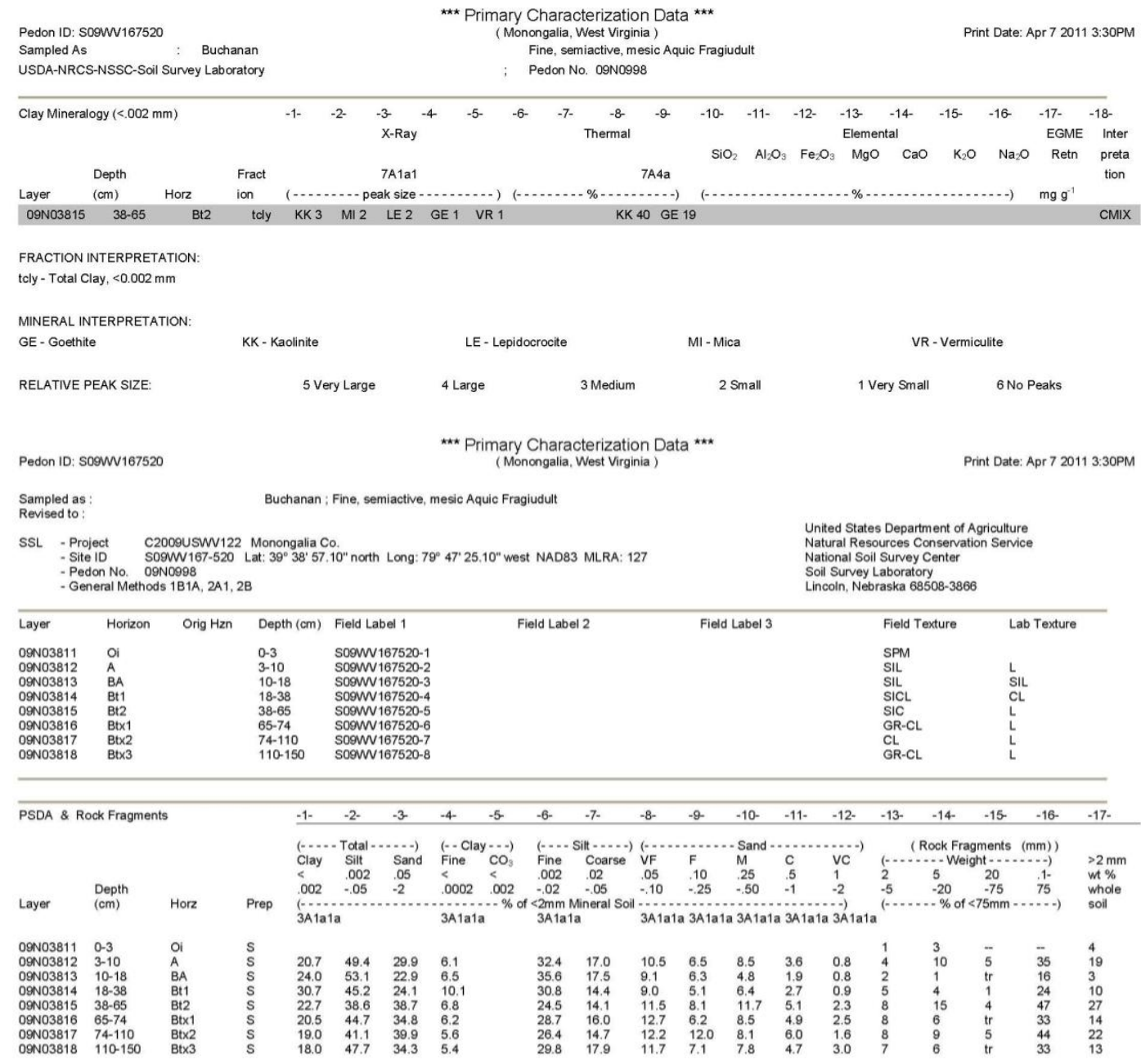




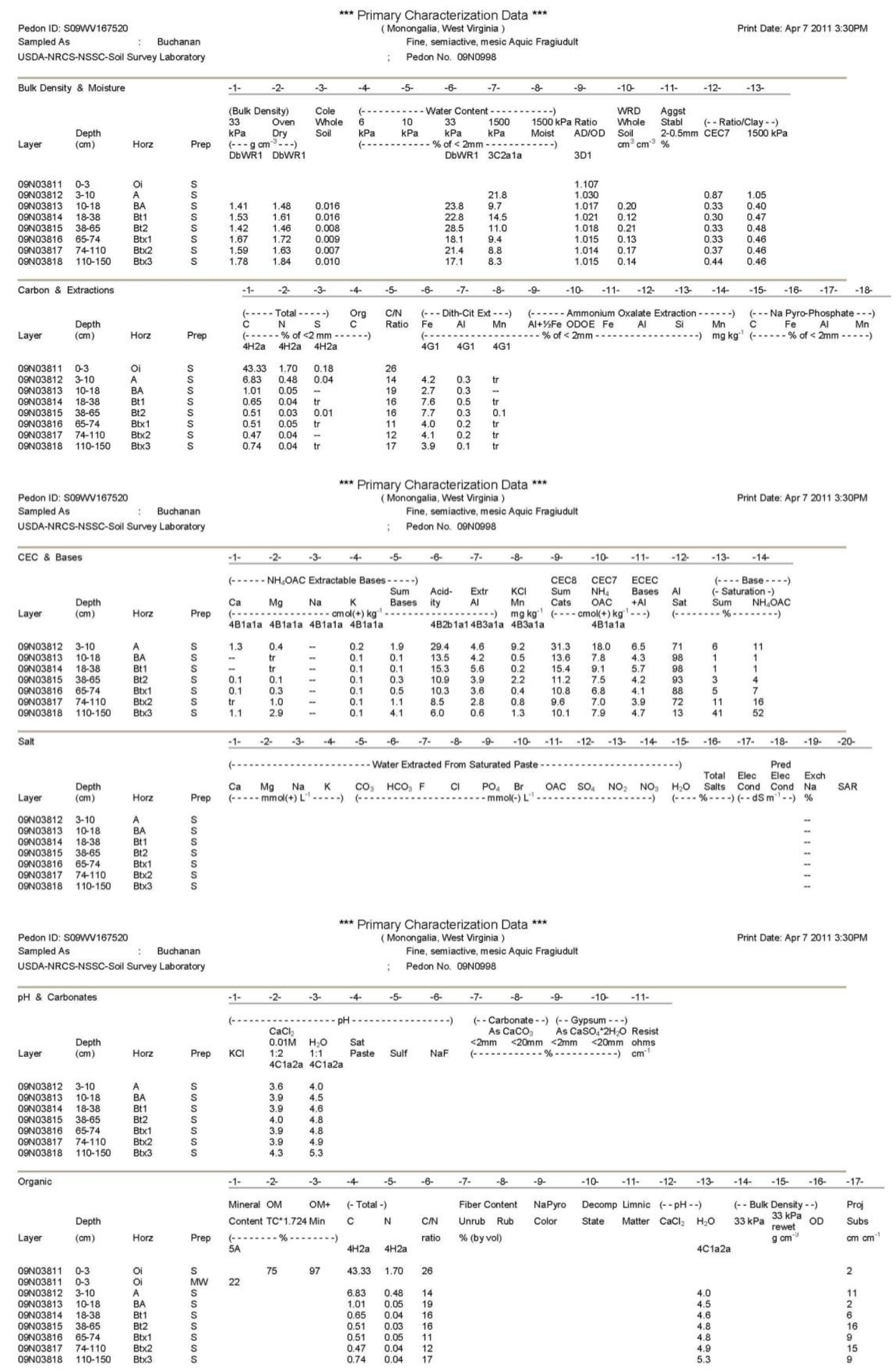




\section{NSSL Site Backslope (north)}

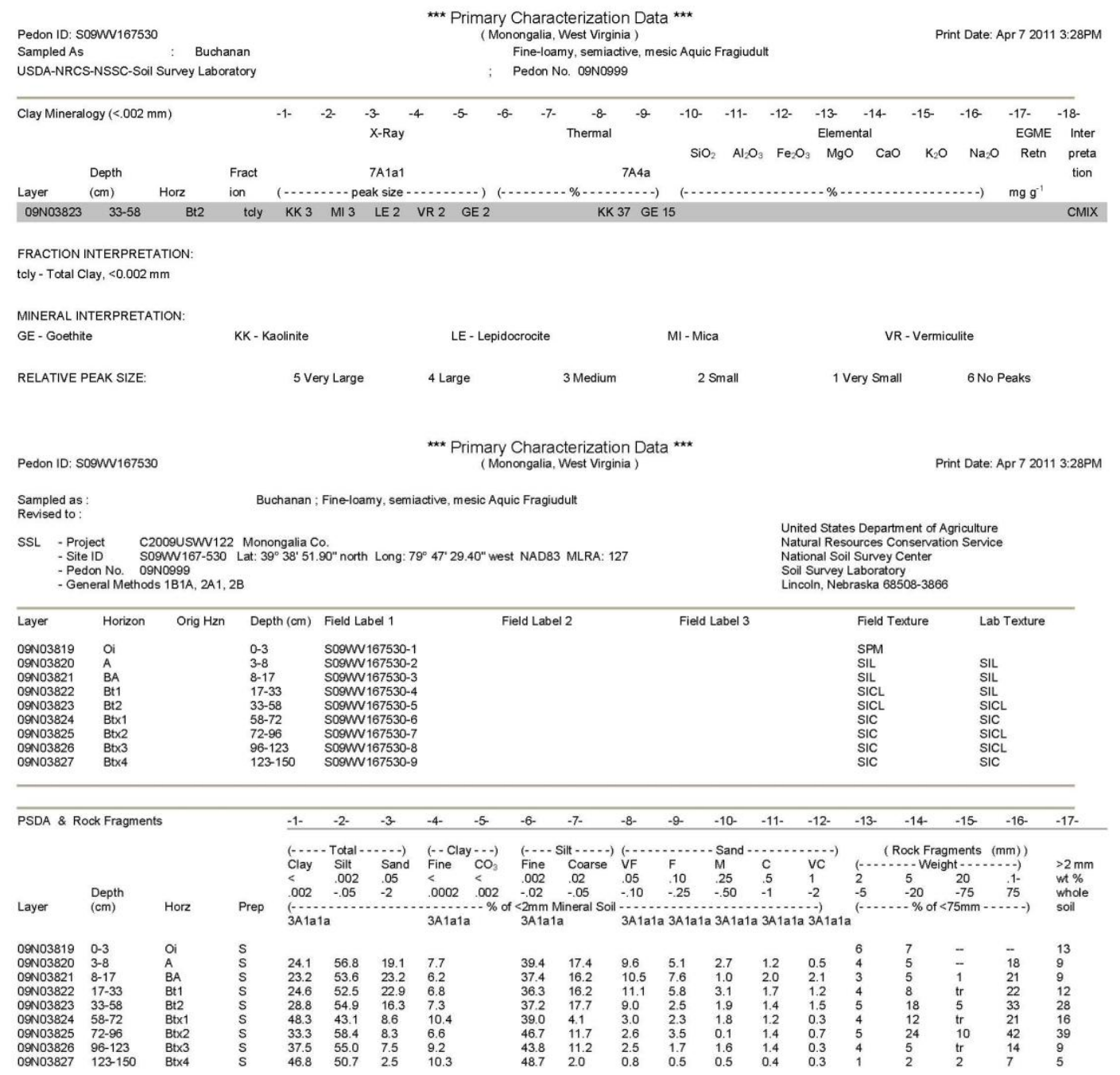




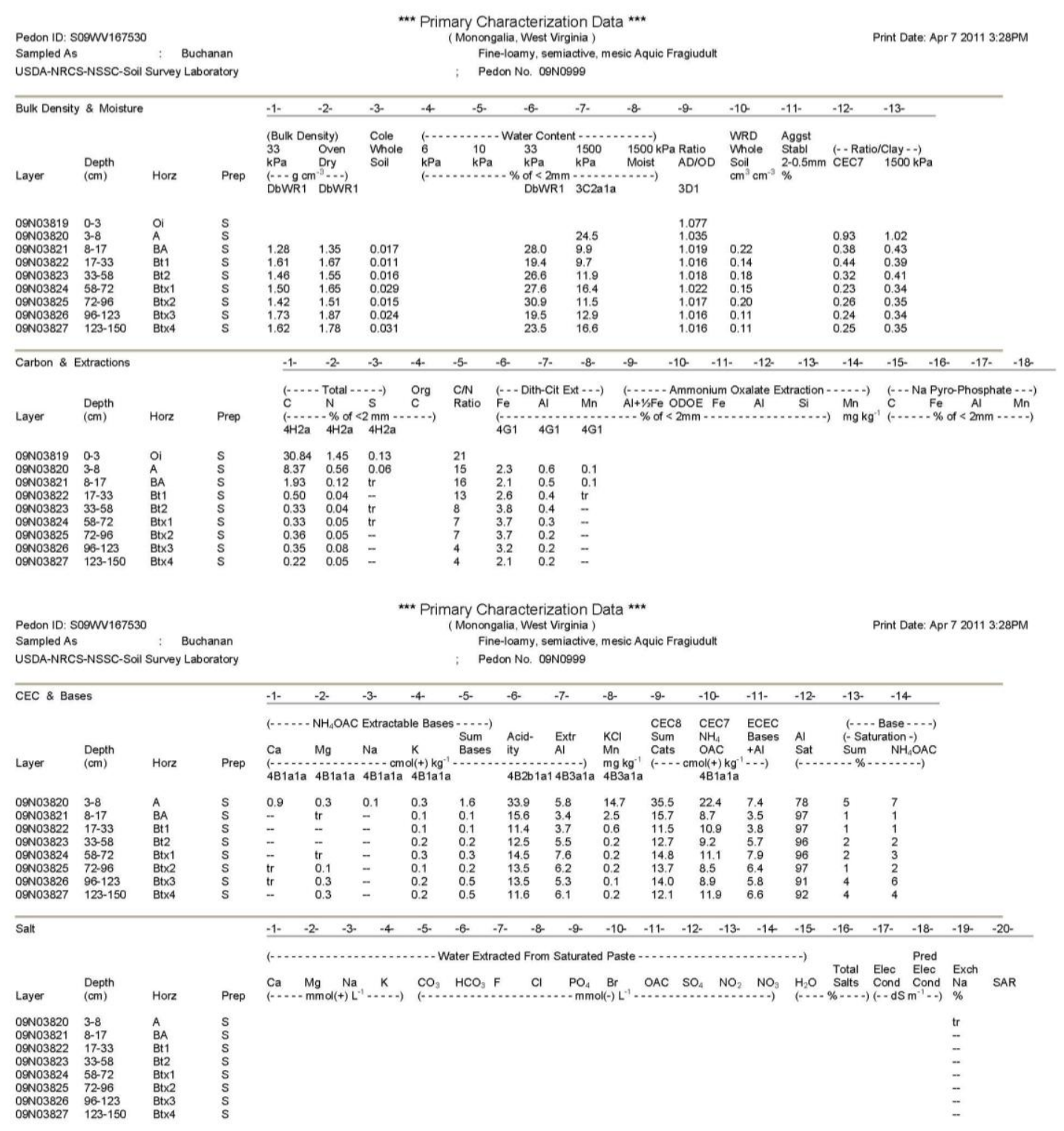




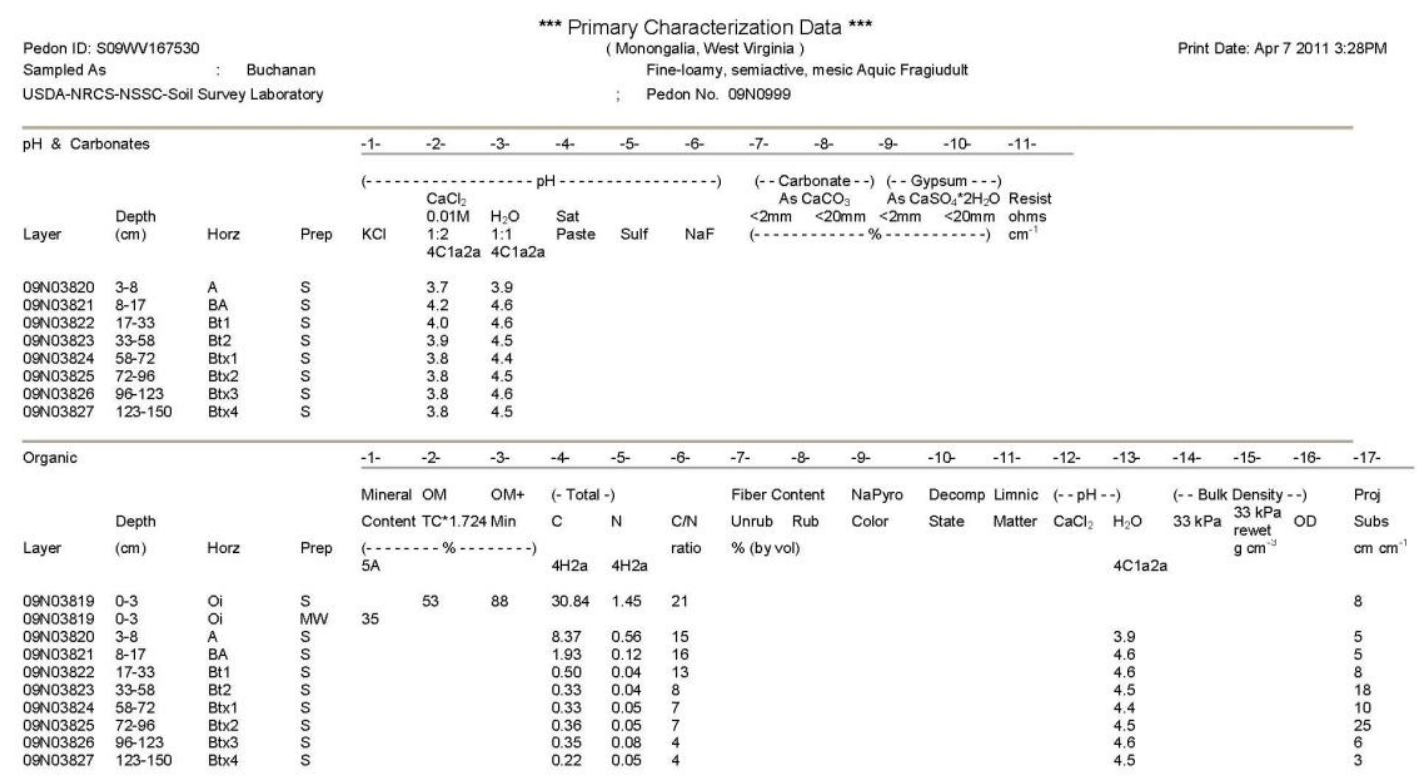




\subsubsection{NSSL Site Summit (north)}

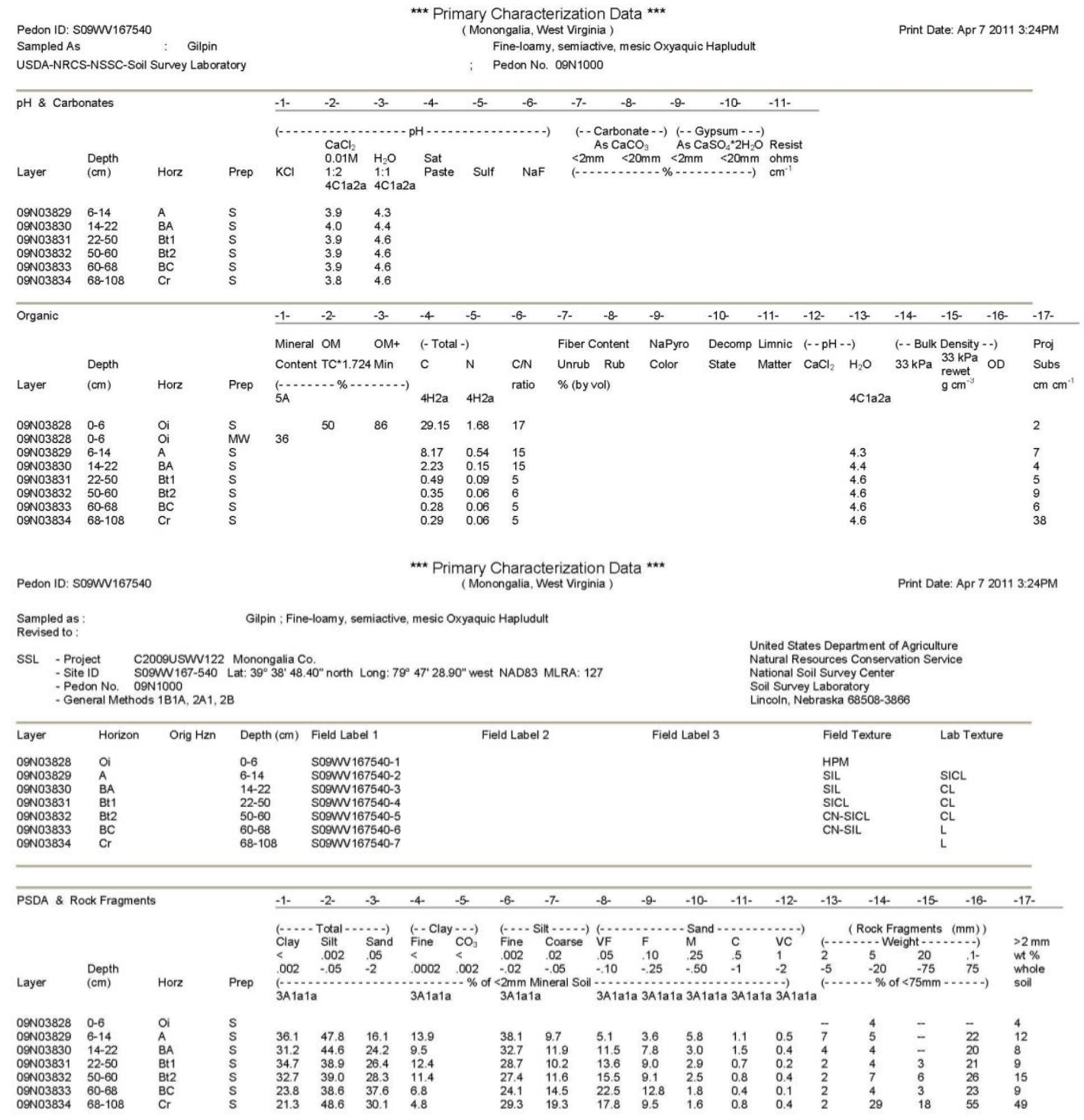




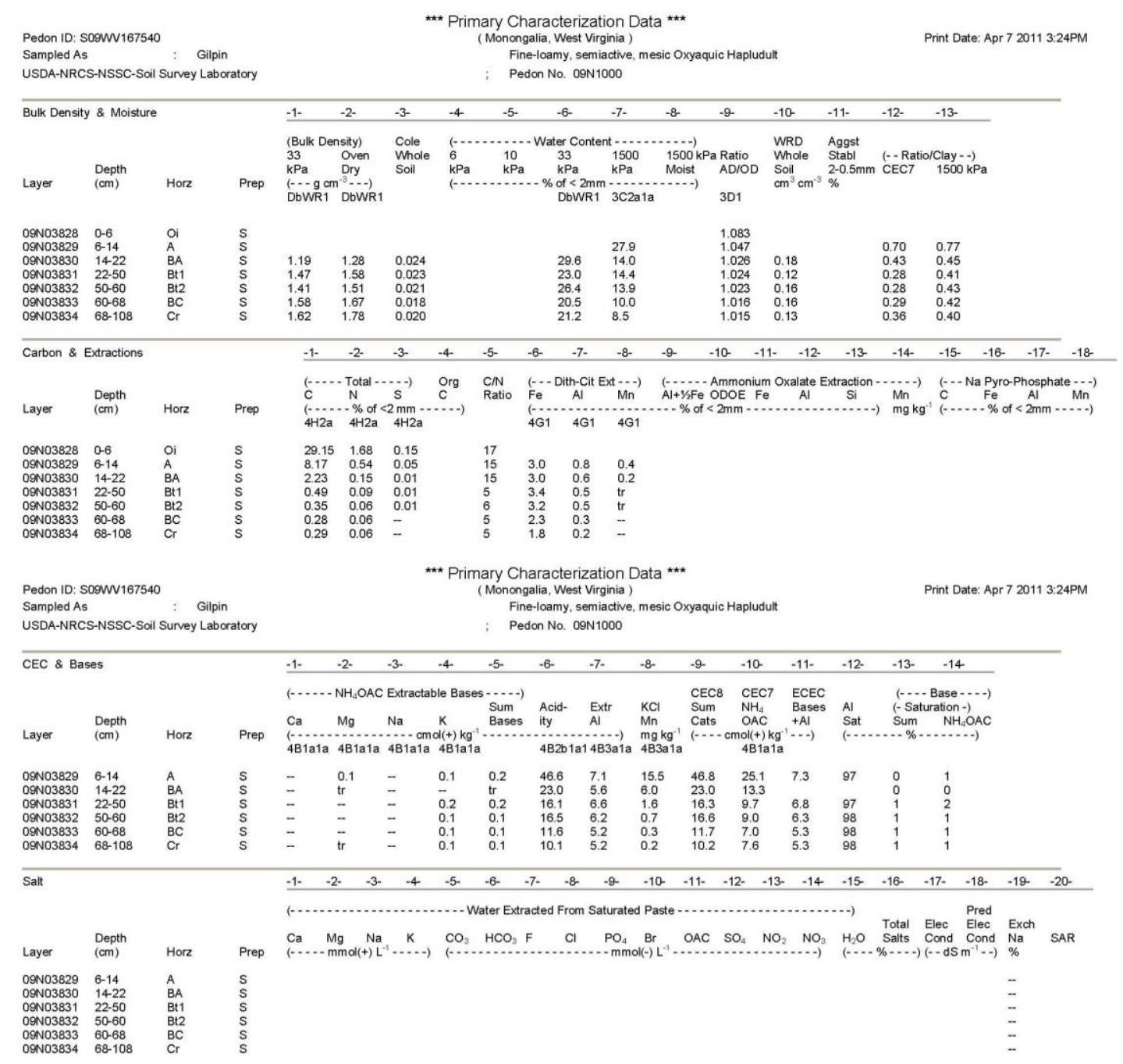




\subsection{Frame Bulk Density}

\subsubsection{Frame Bulk Density Site Summit (south)}

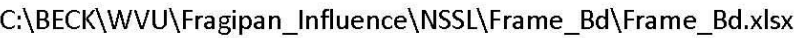

Relative Elevation Method for Bulk Density

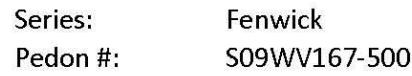

A

2109.44

2105

43.6

2061.4

3015

2353

961

2054

1392

0.322297955

1397.014995

1.03

1356. 325238

0.642978818

2.65

0.757366484 


\subsubsection{Frame Bulk Density Site Backslope (south)}

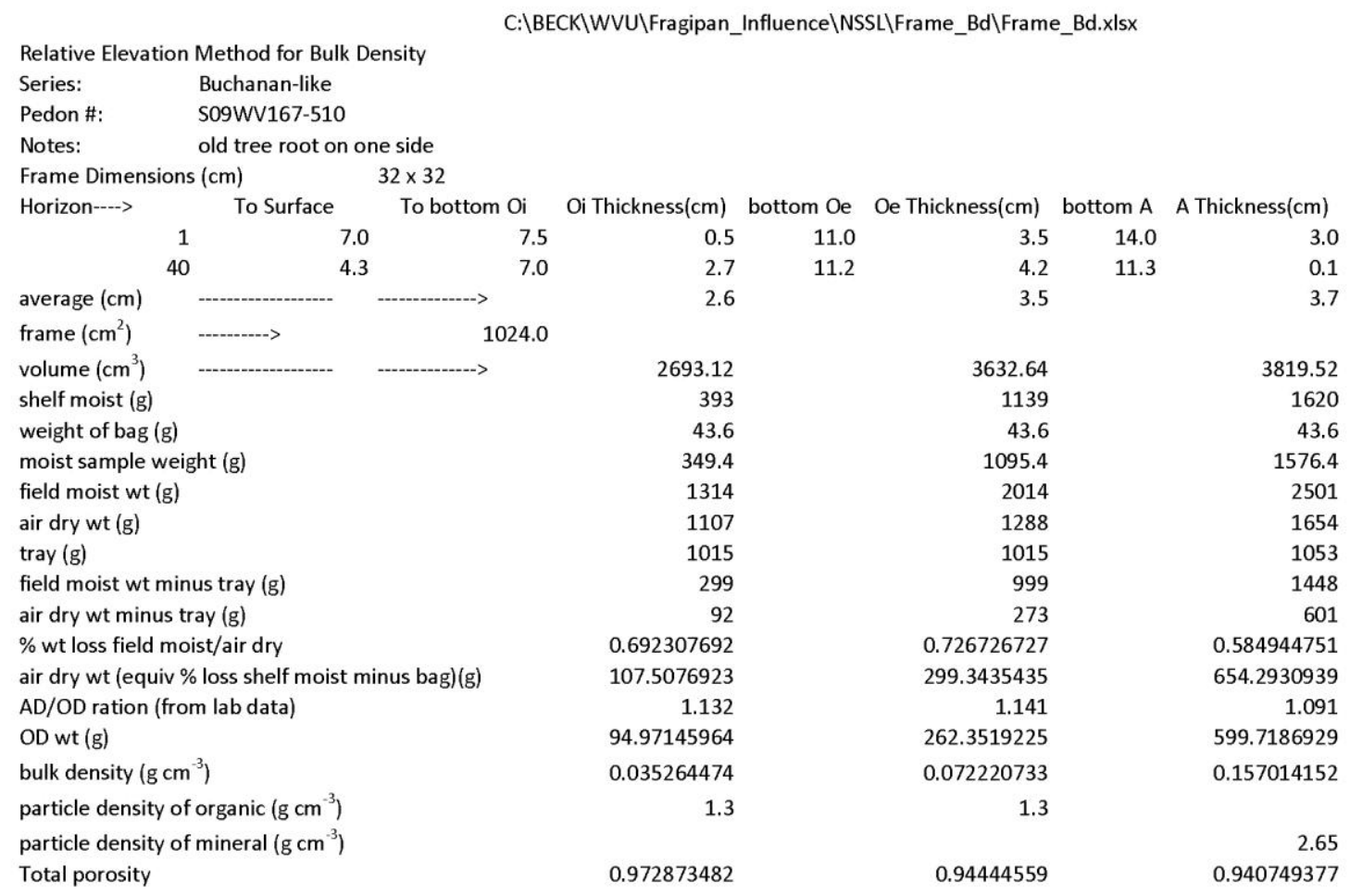




\subsubsection{Frame Bulk Density Site Footslope (south)}

\begin{tabular}{|c|c|c|c|c|c|c|c|}
\hline \multicolumn{8}{|c|}{ C: $\backslash B E C K \backslash W V U \backslash$ Fragipan_Influence $\backslash N S S L \backslash F r a m e \_B d \backslash F r a m e \_B d . x \mid s x$} \\
\hline \multicolumn{8}{|c|}{ Relative Elevation Method for Bulk Density } \\
\hline Series: & \multicolumn{7}{|c|}{$\begin{array}{l}\text { n Method for Bulk Density } \\
\text { Buchanan }\end{array}$} \\
\hline Pedon \#: & \multicolumn{7}{|l|}{ So9WV167-515 } \\
\hline \multicolumn{8}{|l|}{ Notes: } \\
\hline \multicolumn{2}{|c|}{ Frame Dimensions $(\mathrm{cm})$} & \multicolumn{6}{|l|}{$32 \times 32$} \\
\hline Horizon----> & To Surface & To bottom Oi & Oi Thickness $(\mathrm{cm})$ & bottom Oe & Oe Thickness $(\mathrm{cm})$ & bottom A & A Thickness $(\mathrm{cm})$ \\
\hline & 4.3 & 6.5 & 2.2 & 9.9 & 3.4 & 13.0 & 3.1 \\
\hline 4 & 5.3 & 6.8 & 1.5 & 10.5 & 3.7 & 14.1 & 3.6 \\
\hline average $(\mathrm{cm})$ & 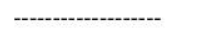 & -.--------> & 1.5 & & 3.9 & & 3.4 \\
\hline frame $\left(\mathrm{cm}^{2}\right)$ & -..----> & 1024.0 & & & & & \\
\hline volume $\left(\mathrm{cm}^{3}\right)$ & 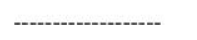 & - & 1484.8 & & 3968 & & 3494.4 \\
\hline shelf moist (g) & & & 258 & & 1128 & & 2644 \\
\hline weight of bag ( $\mathrm{g}$ & & & 43.6 & & 43.6 & & 43.6 \\
\hline moist sample we & ight (g) & & 214.4 & & 1084.4 & & 2600.4 \\
\hline field moist wt (g & & & 1181 & & 1975 & & 3550 \\
\hline air dry wt (g) & & & 1077 & & 1338 & & 2603 \\
\hline tray $(\mathrm{g})$ & & & 1020 & & 976 & & 965 \\
\hline field moist wt $\mathrm{m}$ & nus tray $(\mathrm{g})$ & & 161 & & 999 & & 2585 \\
\hline air dry wt minus & tray (g) & & 57 & & 362 & & 1638 \\
\hline$\%$ wt loss field $\mathrm{m}$ & oist/air dry & & 0.645962733 & & 0.637637638 & & 0.366344294 \\
\hline air dry wt (equiv & $\%$ loss shelf moist $n$ & minus bag)(g) & 75.90559006 & & 392.9457457 & & 1647.758298 \\
\hline$A D / O D$ ration $(\mathrm{fr}$ & om lab data) & & 1.127 & & 1.138 & & 1.039 \\
\hline OD wt (g) & & & 67.3518989 & & 345.2950314 & & 1585.90789 \\
\hline bulk density ( $\mathrm{g} \mathrm{c}$ & & & 0.045360923 & & 0.087019917 & & 0.453842688 \\
\hline particle density & f organic $\left(\mathrm{g} \mathrm{cm}^{-3}\right)$ & & 1.3 & & 1.3 & & \\
\hline particle density & f mineral $\left(\mathrm{g} \mathrm{cm}^{-3}\right)$ & & & & & & 2.65 \\
\hline Total porosity & & & 0.965106982 & & 0.933061602 & & 0.828738608 \\
\hline
\end{tabular}




\subsubsection{Frame Bulk Density Site Footslope (north)}

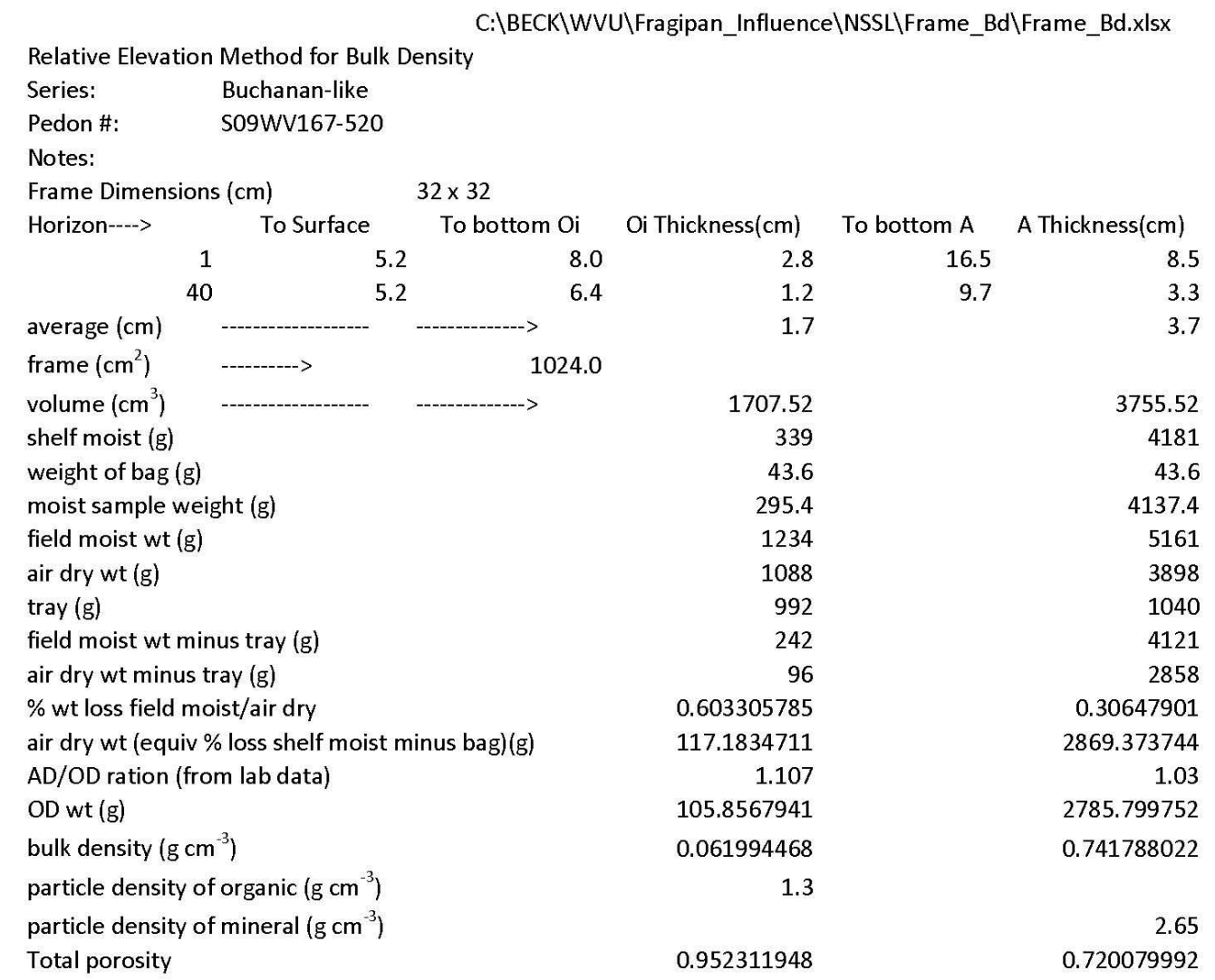




\subsubsection{Frame Bulk Density Site Backslope (north)}

$C: \backslash B E C K \backslash W V U \backslash F r a g i p a n \_I n f l u e n c e \backslash N S S L \backslash F r a m e \_B d \backslash F r a m e \_B d . x l s x$

Relative Elevation Method for Bulk Density

Series: Buchanan

Pedon \#: $\quad$ S09WV167-530

Notes:

Frame Dimensions $(\mathrm{cm})$

Horizon---> To Surface To bottom Oi Oi Thickness $(\mathrm{cm})$ To bottom A A Thickness $(\mathrm{cm})$

$\begin{array}{rrrrrr}1 & 5.4 & 6.0 & 0.6 & 7.7 & 1.7 \\ 40 & 5.5 & 7.0 & 1.5 & 9.1\end{array}$

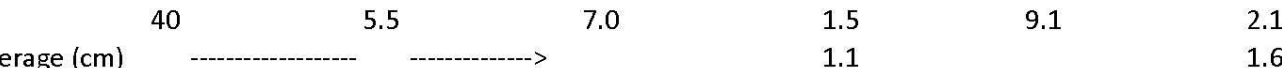

frame $\left(\mathrm{cm}^{2}\right) \quad-1024.0$

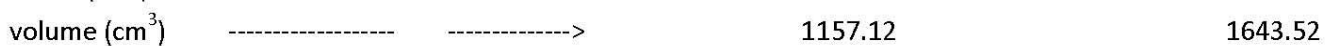

shelf moist (g) $\quad 451 \quad 1515$

weight of bag (g) $\quad 43.6 \quad 43.6$

$\begin{array}{lll}\text { moist sample weight }(\mathrm{g}) & 407.4 & 1471.4\end{array}$

field moist wt (g) $\quad 1288 \quad 2479$

$\begin{array}{lll}\text { air dry wt }(\mathrm{g}) & 1114 & 2028\end{array}$

$\begin{array}{lll}\text { tray }(\mathrm{g}) & 949 & 1019\end{array}$

field moist wt minus tray (g) $\quad 339 \quad 1460$

air dry wt minus tray (g) $\quad 165 \quad 1009$

$\begin{array}{llr}\% \text { wt loss field moist/air dry } & 0.513274336 & 0.30890411\end{array}$

air dry wt (equiv \% loss shelf moist minus bag)(g) $\quad 198.2920354 \quad 1016.878493$

AD/OD ration (from lab data) $\quad 1.077 \quad 1.035$

OD wt (g) $\quad 184.1151675$

982.4912977

bulk density $\left(\mathrm{g} \mathrm{cm}^{-3}\right)$

0.159115016

0.597796983

particle density of organic $\left(\mathrm{g} \mathrm{cm}^{-3}\right)$

1.3

particle density of mineral $\left(\mathrm{g} \mathrm{cm}^{-3}\right)$

2.65

Total porosity

0.877603834

0.774416233 


\subsubsection{Frame Bulk Density Site Summit (north)}

\begin{tabular}{|c|c|c|c|c|c|}
\hline \multicolumn{6}{|c|}{ 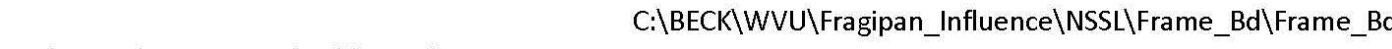 } \\
\hline \multicolumn{6}{|c|}{ Relative Elevation Method for Bulk Density } \\
\hline Series: & \multicolumn{5}{|c|}{ Gilpin } \\
\hline Pedon \#: & \multicolumn{5}{|l|}{ so9wV167-540 } \\
\hline \multicolumn{6}{|l|}{ Notes: } \\
\hline \multicolumn{2}{|c|}{ Frame Dimensions (cm) } & \multicolumn{4}{|l|}{$32 \times 32$} \\
\hline \multirow[t]{3}{*}{ Horizon----> } & To Surface & To bottom Oi & Oi Thickness $(\mathrm{cm})$ & To bottom A & A Thickness $(\mathrm{cm})$ \\
\hline & 4.5 & 6.6 & 2.1 & 10.9 & 4.3 \\
\hline & 3.8 & 6.5 & 2.7 & 11.0 & 4.5 \\
\hline average $(\mathrm{cm})$ & 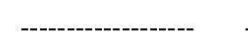 & 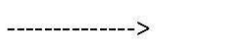 & 2.7 & & 4.5 \\
\hline frame $\left(\mathrm{cm}^{2}\right)$ & ---------> & 1024.0 & & & \\
\hline volume $\left(\mathrm{cm}^{3}\right)$ & ------------------ & ------------->> & 2810.88 & & 4597.76 \\
\hline shelf moist (g) & & & 690 & & 4783 \\
\hline weight of bag (g & & & 43.6 & & 43.6 \\
\hline moist sample we & eight (g) & & 646.4 & & 4739.4 \\
\hline field moist wt (g & & & 1555 & & 5680 \\
\hline air dry wt (g) & & & 1249 & & 4256 \\
\hline tray (g) & & & 974 & & 999 \\
\hline field moist wt $\mathrm{m}$ & inus tray $(\mathrm{g})$ & & 581 & & 4681 \\
\hline air dry wt minus & $\operatorname{tray}(\mathrm{g})$ & & 275 & & 3257 \\
\hline$\%$ wt loss field m & oist/air dry & & 0.526678141 & & 0.304208502 \\
\hline air dry wt (equiv & $\%$ loss shelf moist $m$ & ninus bag)(g) & 305.9552496 & & 3297.634223 \\
\hline$A D / O D$ ration $(\mathrm{fr}$ & om lab data) & & 1.083 & & 1.047 \\
\hline OD wt (g) & & & 282.5071557 & & 3149.602888 \\
\hline bulk density ( $\mathrm{g} \mathrm{c}$ & $\left.m^{-3}\right)$ & & 0.100504879 & & 0.68502986 \\
\hline particle density & f organic $\left(\mathrm{g} \mathrm{cm}^{-3}\right)$ & & 1.3 & & \\
\hline particle density & f mineral $\left(\mathrm{g} \mathrm{cm}^{-3}\right)$ & & & & 2.65 \\
\hline Total porosity & & & 0.922688554 & & 0.741498166 \\
\hline
\end{tabular}




\subsection{Schema of Sensors/Probes Installation}

\subsubsection{Schema of Sensors/Probes Site Summit (south)}

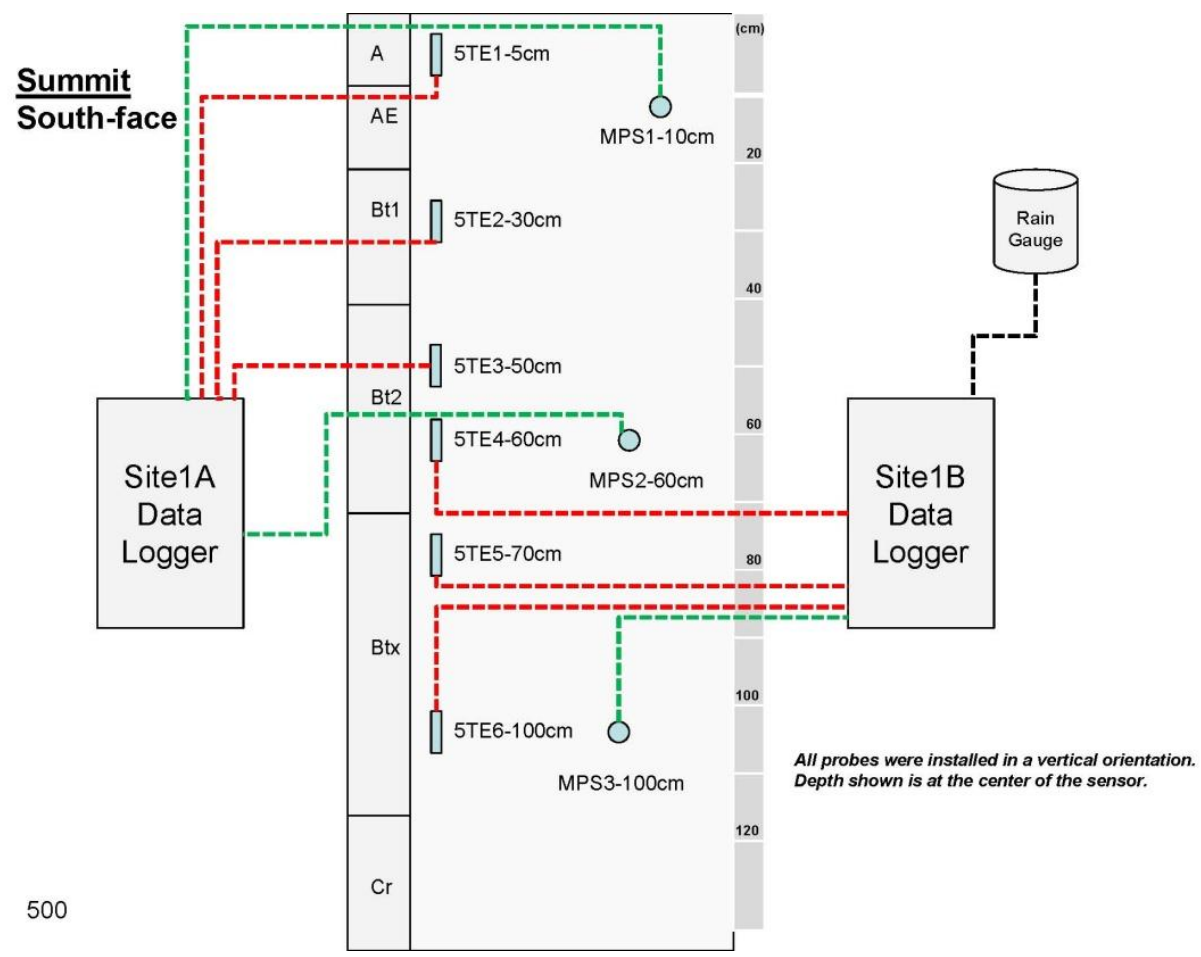




\subsubsection{Schema of Sensors/Probes Site Backslope (south)}

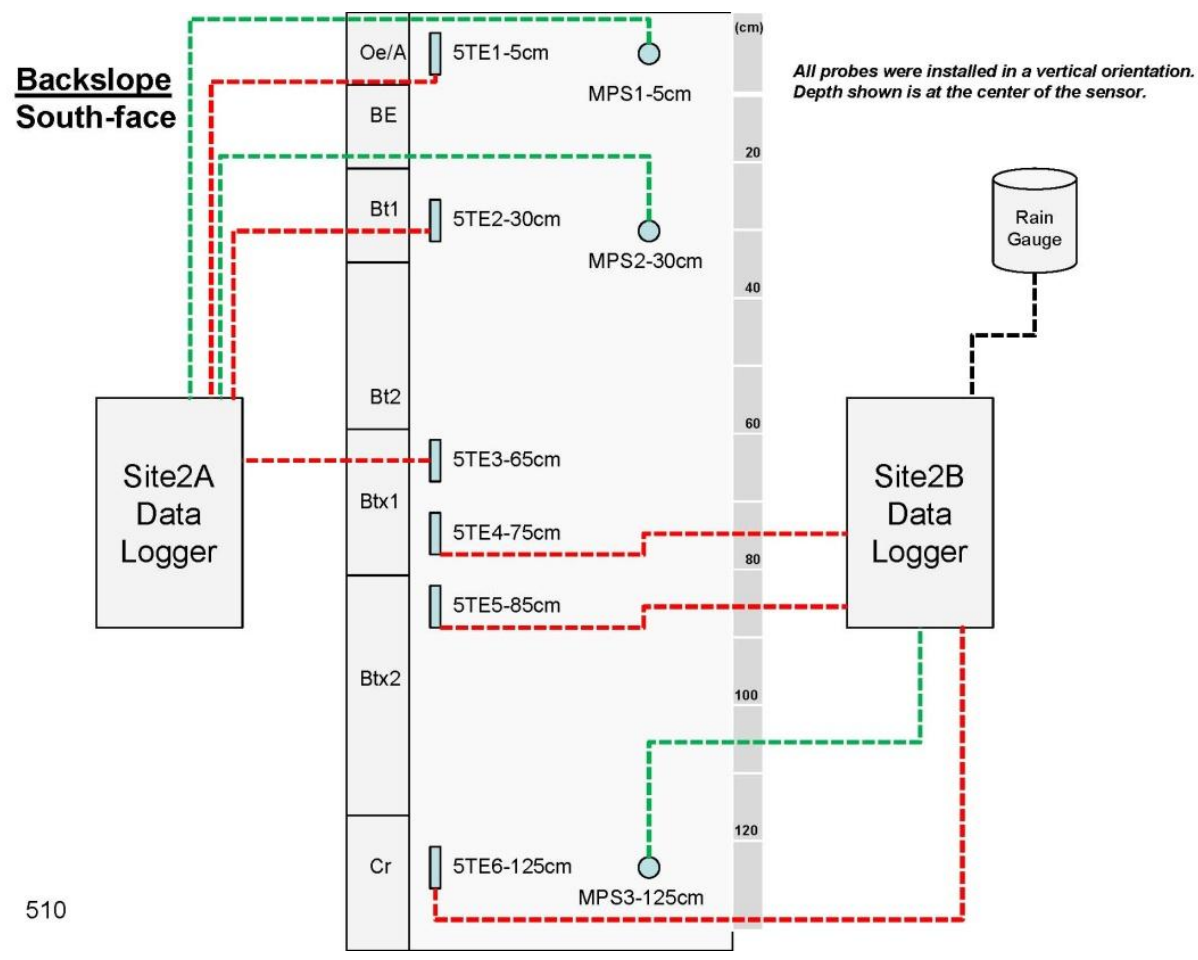

\subsubsection{Schema of Sensors/Probes Site Footslope (south)}

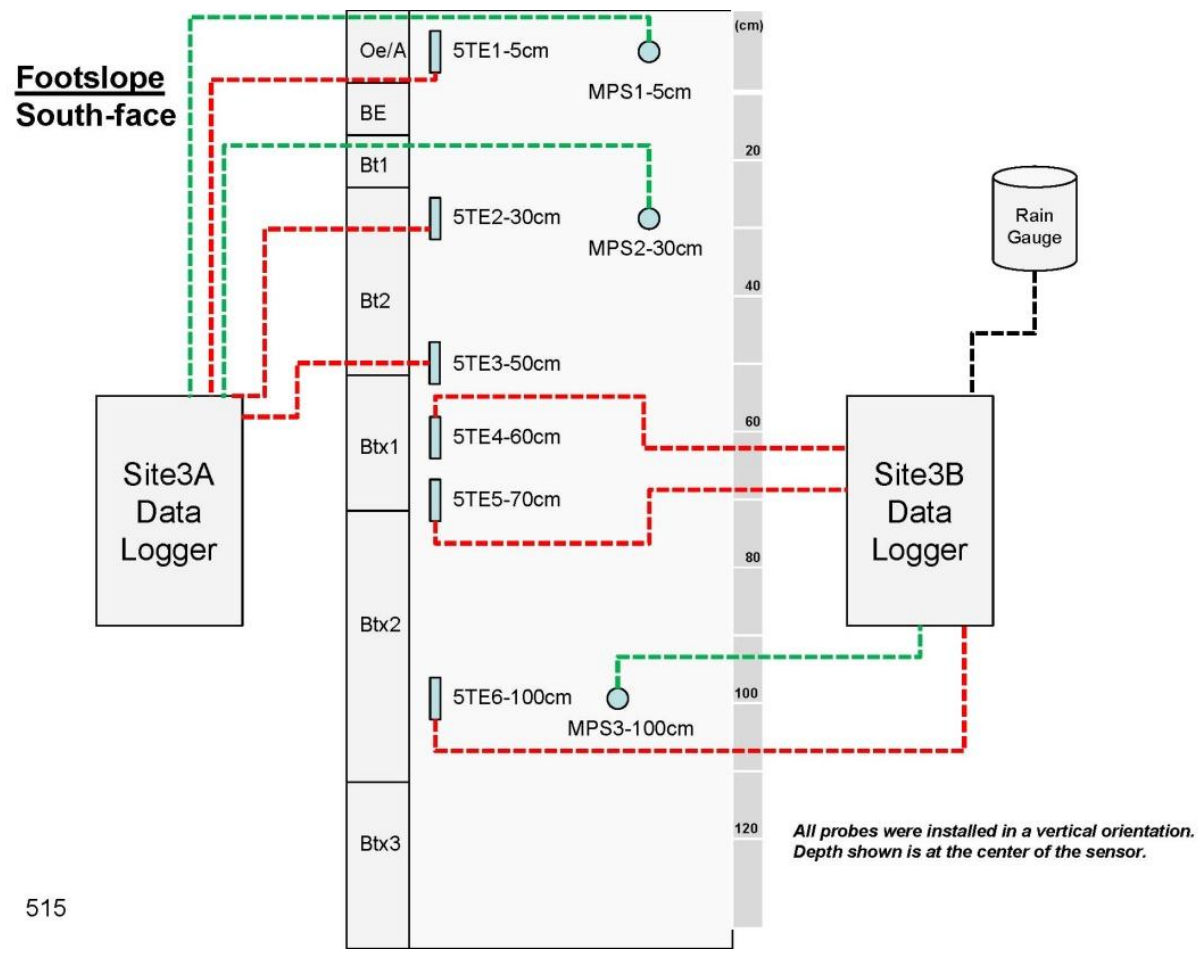




\subsubsection{Schema of Sensors/Probes Site Footslope (north)}

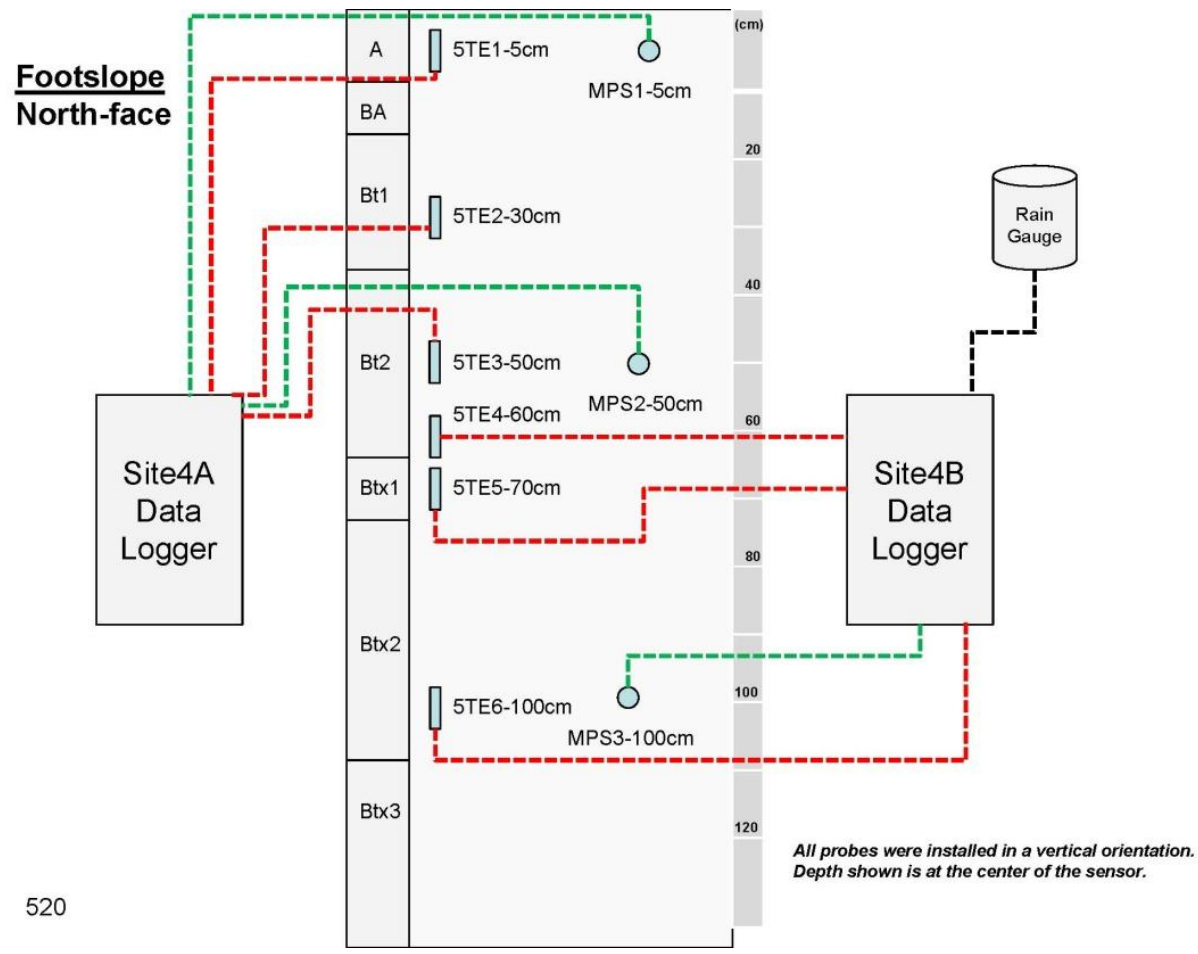

6.3.5. Schema of Sensors/Probes Site Backslope (north)

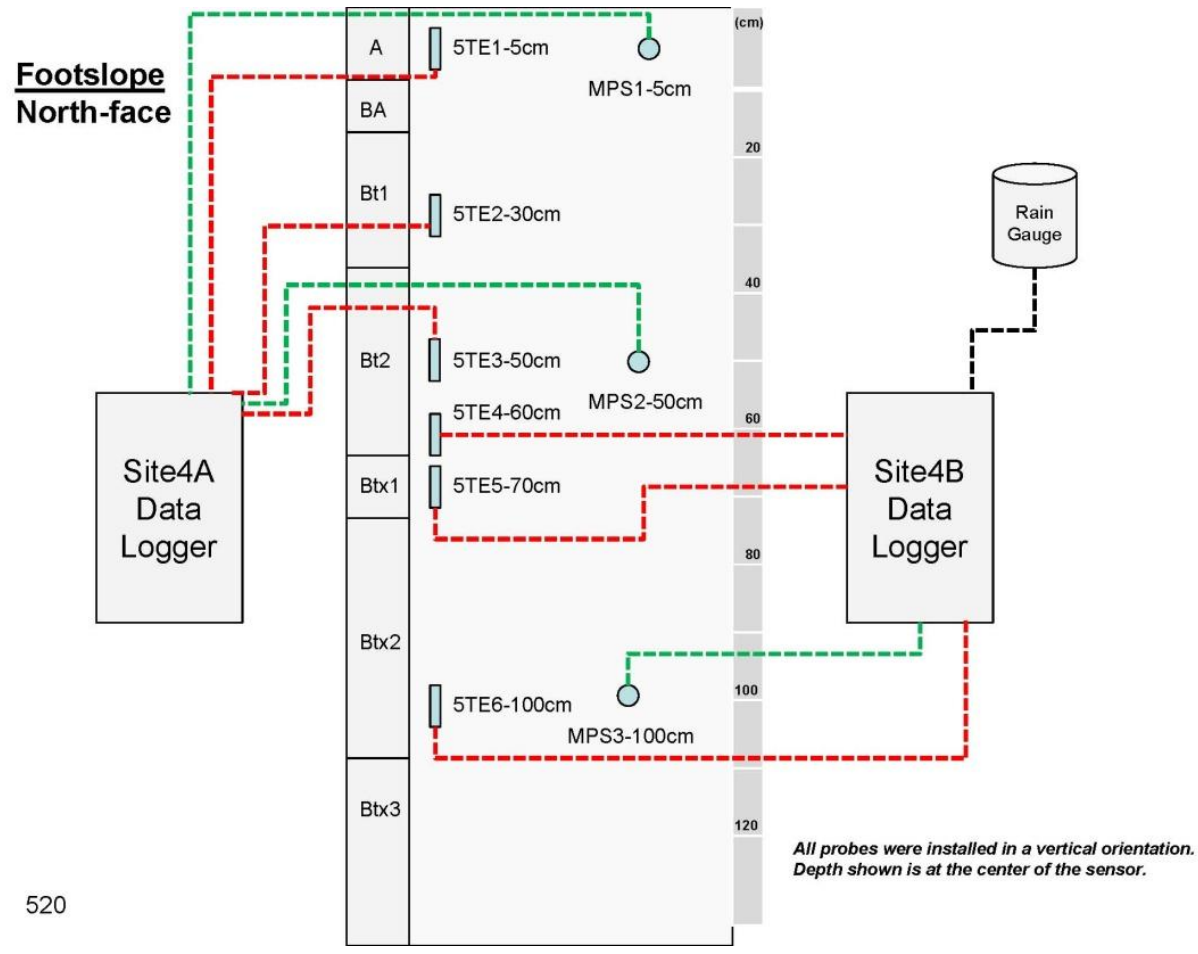




\subsubsection{Schema of Sensors/Probes Site Summit (north)}

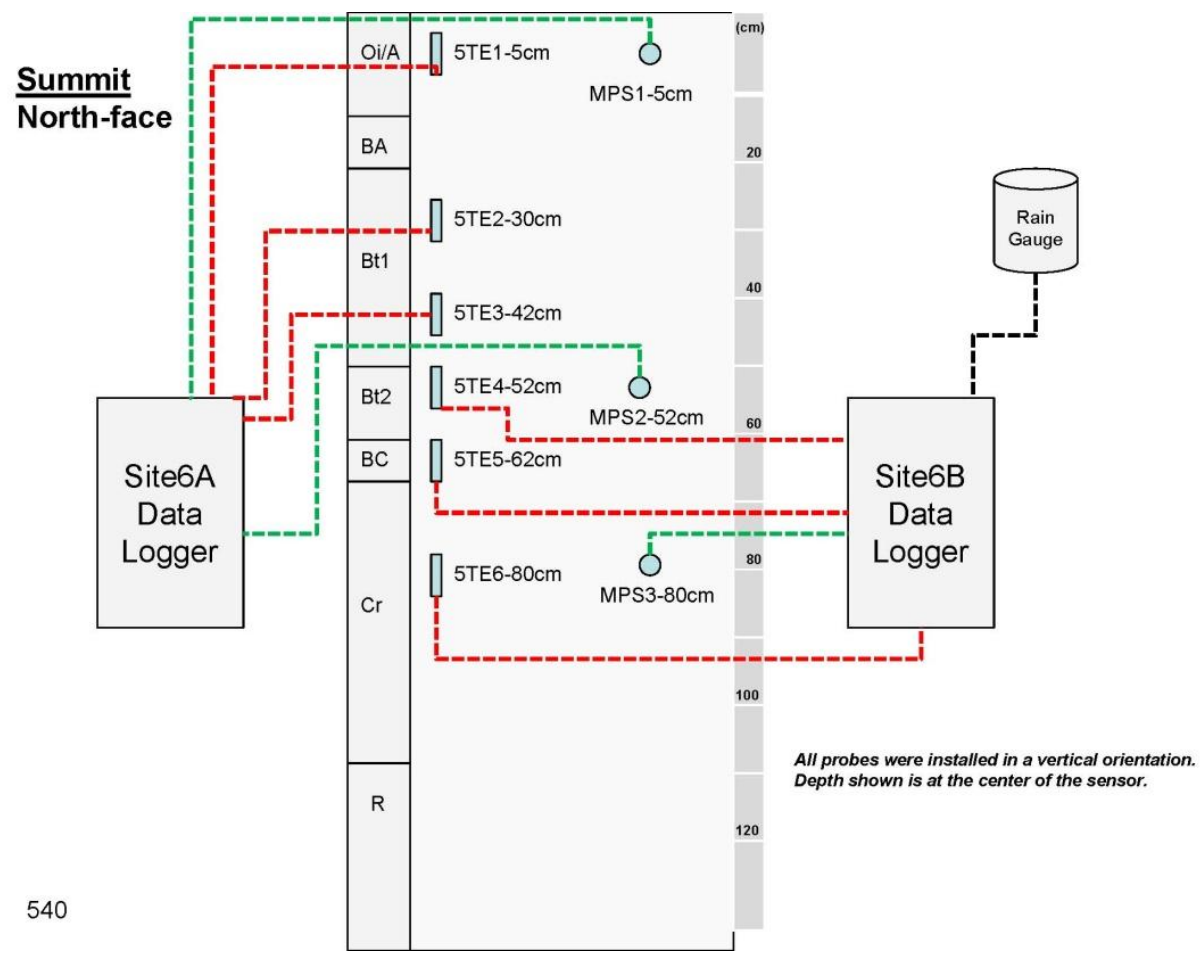




\subsection{Pedon Descriptions}

\subsubsection{Pedon Description Site Summit (south)}

Site Record ID: 21

Pedon Record ID: 21

Pedon ID: S09WV167-500

Site ID: S09WV167-500

Lab Pedon \#:S09WV167-500

Description Date: 7/31/2009

Print Date: 8/8/2009

Describer: BECK

Site Notes: Pedon Notes:

Soil Name As Described/Sampled: Fenwick

Soil Name As Correlated:

Classification:

Pedon Type:

Pedon Purpose:

Taxon Kind:

SSURGO MU:

Lat/Long: 39³9'6.5” north, 7947'23.1” west

UTM: 603830.75E, 4389812.11N -- Datum NAD83, Zone 17

Location Description:

Legal Description:

Landscape:

Landform:

Microfeature:

Anthropogenic Feature:

Geomorphic Component: Interfluve

Profile Pos: Summit

Slope: 10 percent

Elevation: 666.7 meters

Aspect: $210^{\circ}$

Shape: up/down: Linear; across: Linear

Complexity: Simple

Flooding:

Ponding:

Drainage: Moderately well drained

Runoff:

Permeability: 


\section{Erosion:}

\section{Primary Earth Cover: ; Secondary Earth Cover:}

\section{Parent Materials:}

Bedrock: Moderately cemented shale at 150 centimeters

\section{Particle Size Control Section:}

\begin{tabular}{|c|c|c|c|c|c|c|c|c|c|c|}
\hline Slope & $\begin{array}{c}\text { Elevatio } \\
\mathbf{n}\end{array}$ & $\begin{array}{c}\text { Aspec } \\
\mathbf{t}\end{array}$ & $\begin{array}{c}\text { MAA } \\
\mathbf{T}\end{array}$ & $\begin{array}{c}\text { MSA } \\
\mathbf{T}\end{array}$ & $\begin{array}{c}\text { MWA } \\
\mathbf{T}\end{array}$ & $\begin{array}{c}\text { MA } \\
\mathbf{P}\end{array}$ & $\begin{array}{l}\text { Frost } \\
\text {-Free } \\
\text { Days }\end{array}$ & $\begin{array}{c}\text { Drainage } \\
\text { Class }\end{array}$ & \begin{tabular}{|c|} 
Slope \\
Lengt \\
h
\end{tabular} & \begin{tabular}{|c} 
Upslop \\
e \\
Length
\end{tabular} \\
\hline $\begin{array}{l}10 \\
\text { percen } \\
t\end{array}$ & $\begin{array}{l}666.7 \\
\text { meters }\end{array}$ & $210^{\circ}$ & & & & & & $\begin{array}{l}\text { moderatel } \\
\text { y well }\end{array}$ & & \\
\hline
\end{tabular}

Oi --- 0 to 3 centimeters; black (10YR 2/1) moist, slightly decomposed plant material; structureless structure; common medium roots throughout, common very fine roots throughout and common fine roots throughout; clear smooth boundary.

A --- 3 to 7 centimeters; very dark grayish brown (10YR 3/2) moist, broken face, loam; moderate medium granular structure; common coarse roots throughout, common medium roots throughout, common fine roots throughout and common very fine roots throughout; 5 percent flat subangular strongly cemented 2 to 150 millimeters sandstone fragments; abrupt smooth boundary.

AE --- 7 to 15 centimeters; yellowish brown (10YR 5/4) moist, broken face, silt loam; weak medium subangular blocky structure; common coarse roots throughout, common medium roots throughout, common fine roots throughout and common very fine roots throughout; 10 percent flat subangular strongly cemented 2 to 150 millimeters sandstone fragments; clear wavy boundary.

Bt1 --- 15 to 47 centimeters; dark yellowish brown (10YR 4/6) moist, broken face, silty clay loam; moderate medium subangular blocky structure; common medium roots throughout, common fine roots throughout and common very fine roots throughout; 45 percent (common) continuous faint yellowish brown (10YR 5/4), moist, clay films on all faces of peds; 10 percent flat subangular strongly cemented 2 to 150 millimeters sandstone fragments; gradual wavy boundary.

Bt2 --- 47 to 66 centimeters; yellowish brown (10YR 5/6) moist, broken face, silty clay loam; strong medium subangular blocky structure; common medium roots throughout, common fine roots throughout and common very fine roots throughout; 45 percent (common) continuous faint yellowish brown (10YR 5/4), moist, clay films on all faces of peds; 5 percent (common) medium distinct strong brown (7.5YR 5/8), moist, iron-manganese masses throughout and 10 percent (common) medium distinct light gray (10YR 7/2), moist, iron depletions throughout; 10 percent flat subangular strongly cemented 2 to 150 millimeters sandstone fragments; gradual wavy boundary. 
Btx --- 66 to 102 centimeters; dark yellowish brown (10YR 4/6) moist, broken face, silty clay loam; strong medium prismatic parting to weak fine platy structure; common fine roots between peds, common very fine roots between peds, common fine roots in mat at top of horizon and common very fine roots in mat at top of horizon; 45 percent (common) continuous faint brown (10YR 5/3), moist, clay films on top faces of peds and 45 percent (common) continuous faint brown (10YR 5/3), moist, clay films on vertical faces of peds; 5 percent (common) medium strong brown (7.5YR 5/8), moist, iron-manganese masses and 15 percent (common) medium grayish brown (2.5Y 5/2), moist, iron depletions; 10 percent flat subangular strongly cemented 2 to 150 millimeters sandstone fragments; clear wavy boundary.

Cr --- 102 to 150 centimeters; dark yellowish brown (10YR 4/4) moist, exterior; common very fine roots between peds and common fine roots between peds. 


\subsubsection{Pedon Description Site Backslope (south)}

Site Record ID: 22

Pedon Record ID: 24

Pedon ID: S09WV167-510

Site ID: S09WV167-510

Lab Pedon \#:S09WV167-510

Description Date: 7/28/2009

Print Date: 8/8/2009

Describer: SATTLER/BECK

Site Notes: Pedon Notes:

Soil Name As Described/Sampled: Buchanan-like

Soil Name As Correlated:

Classification:

Pedon Type:

Pedon Purpose:

Taxon Kind:

SSURGO MU:

Lat/Long: 39³9'1.6” north, 7947'23.2” west

UTM: 603813.99E, 4389648.46N -- Datum NAD83, Zone 17

Location Description:

Legal Description:

Landscape:

Landform:

Microfeature:

Anthropogenic Feature:

Geomorphic Component: Side Slope

Profile Pos: Backslope: on lower third

Slope: 15 percent

Elevation: 643.6 meters

Aspect: $118^{\circ}$

Shape: up/down: Linear; across: Linear

Complexity: Simple

Flooding:

Ponding:

Drainage:

Runoff:

Permeability:

Erosion:

Primary Earth Cover: ; Secondary Earth Cover:

Parent Materials: 
Bedrock: Moderately cemented shale at 175 centimeters

Particle Size Control Section:

\begin{tabular}{|l|l|l|l|l|l|l|l|l|l|l|}
\hline Slope & $\begin{array}{c}\text { Elevatio } \\
\mathbf{n}\end{array}$ & $\begin{array}{c}\text { Aspec } \\
\mathbf{t}\end{array}$ & $\begin{array}{c}\text { MAA } \\
\mathbf{T}\end{array}$ & $\begin{array}{c}\text { MSA } \\
\mathbf{T}\end{array}$ & $\begin{array}{c}\text { MWA } \\
\mathbf{T}\end{array}$ & $\begin{array}{c}\text { MA } \\
\mathbf{P}\end{array}$ & $\begin{array}{c}\text { Frost } \\
\text {-Free } \\
\text { Days }\end{array}$ & $\begin{array}{c}\text { Drainag } \\
\text { e Class }\end{array}$ & $\begin{array}{c}\text { Slope } \\
\text { Lengt } \\
\text { h }\end{array}$ & $\begin{array}{c}\text { Upslop } \\
\text { Length }\end{array}$ \\
\hline $\begin{array}{l}15 \\
\text { percen } \\
\mathrm{t}\end{array}$ & $\begin{array}{l}643.6 \\
\text { meters }\end{array}$ & $118^{\circ}$ & & & & & & & & \\
\hline
\end{tabular}

Oi --- 0 to 3 centimeters; black (10YR 2/1) moist, slightly decomposed plant material; structureless structure; clear smooth boundary.

Oe --- 3 to 6 centimeters; black (10YR 2/1) moist, broken face, moderately decomposed plant material; weak medium granular structure; very friable; common medium roots throughout, common fine roots throughout and common very fine roots throughout; abrupt smooth boundary.

A --- 6 to 10 centimeters; very dark grayish brown (10YR 3/2) moist, broken face, loam; moderate medium granular structure; very friable; common medium roots throughout, common fine roots throughout and common very fine roots throughout; extremely acid, $\mathrm{pH} \mathrm{4}$; clear wavy boundary.

BE --- 10 to 24 centimeters; yellowish brown (10YR 5/4) moist, broken face, silt loam; weak medium subangular blocky structure; friable; common coarse roots throughout, common medium roots throughout, common fine roots throughout and common very fine roots throughout; clear wavy boundary.

Bt1 --- 24 to 37 centimeters; dark yellowish brown (10YR 4/6) moist, silty clay loam; moderate medium subangular blocky structure; friable; common medium roots throughout, common fine roots throughout and common very fine roots throughout; 35 percent (common) continuous faint (10Y 5/4), moist, clay films on all faces of peds; clear wavy boundary.

Bt2 --- 37 to 59 centimeters; dark yellowish brown (10YR 4/6) moist, silty clay; moderate medium subangular blocky structure; firm; common medium roots throughout, common fine roots throughout and common very fine roots throughout; 35 percent (common) continuous faint yellowish brown (10YR 5/4), moist, clay films on all faces of peds; 1 percent (few) medium faint iron depletions in matrix; extremely acid, $\mathrm{pH} 4$; gradual wavy boundary.

Btx1 --- 59 to 80 centimeters; yellowish brown (10YR 5/6) moist, silty clay; moderate medium subangular blocky parting to weak medium platy structure; very firm; common fine roots in mat at top of horizon, common very fine roots in mat at top of horizon, common fine roots between peds and common very fine roots between peds; 35 percent (common) continuous faint yellowish brown (10YR 5/4), moist, clay films on top faces of peds and 35 percent (common) continuous faint yellowish brown (10YR 5/4), moist, clay films on vertical faces of 
peds; 5 percent (common) medium distinct brownish yellow (10YR 6/8), moist, ironmanganese masses on vertical faces of peds and 10 percent (common) medium distinct 5 percent light brownish gray (10YR 6/2), moist and 5 percent light gray (10YR 7/2), moist, iron depletions on vertical faces of peds; extremely acid, $\mathrm{pH} 4$; gradual wavy boundary.

Btx2 --- 80 to 117 centimeters; light gray (10YR 7/1) moist, silty clay; strong medium prismatic parting to moderate fine platy structure; very firm; common fine roots between peds and common very fine roots between peds; 35 percent (common) continuous distinct brown (10YR 5/3), moist, clay films on vertical faces of peds; 10 percent (common) medium distinct brownish yellow (10YR 6/8), moist, iron-manganese masses on vertical faces of peds; clear wavy boundary.

Cr --- 117 to 150 centimeters; light gray (10YR 7/1) moist, moderately decomposed plant material; weak medium granular structure; moderate excavation difficulty; common medium roots throughout, common fine roots throughout and common very fine roots throughout. 


\subsubsection{Pedon Description Site Footslope (south)}

Site Record ID: 23

Pedon Record ID: 25

Pedon ID: S09WV167-515

Site ID: S09WV167-515

Lab Pedon \#:S09WV167-515

Description Date: 7/28/2009

Print Date: 8/8/2009

Describer: NOLL/CARPENTER

Site Notes:

Pedon Notes:

Soil Name As Described/Sampled: Buchanan

Soil Name As Correlated:

Classification:

Pedon Type:

Pedon Purpose:

Taxon Kind:

SSURGO MU:

Lat/Long: 39³8'59.8” north, 7947'24.4” west

UTM: 603812.16E, 4389605.18N -- Datum NAD83, Zone 17

Location Description:

Legal Description:

Landscape:

Landform:

Microfeature:

Anthropogenic Feature:

Geomorphic Component: Base Slope

Profile Pos: Footslope

Slope: 7 percent

Elevation: 636.5 meters

Aspect: $220^{\circ}$

Shape: up/down: Concave; across: Linear

Complexity: Simple

Flooding:

Ponding:

Drainage:

Runoff:

Permeability:

Erosion:

Primary Earth Cover: ; Secondary Earth Cover: 


\section{Parent Materials:}

Bedrock:

\section{Particle Size Control Section:}

\begin{tabular}{|l|l|l|l|l|l|l|l|l|l|l|}
\hline Slope & $\begin{array}{c}\text { Elevatio } \\
\mathbf{n}\end{array}$ & $\begin{array}{c}\text { Aspec } \\
\mathbf{t}\end{array}$ & $\begin{array}{c}\text { MAA } \\
\text { T }\end{array}$ & $\begin{array}{c}\text { MSA } \\
\text { T }\end{array}$ & $\begin{array}{c}\text { MWA } \\
\text { T }\end{array}$ & $\begin{array}{c}\text { MA } \\
\text { P }\end{array}$ & $\begin{array}{c}\text { Frost } \\
\text {-Free } \\
\text { Days }\end{array}$ & $\begin{array}{c}\text { Drainag } \\
\text { e Class }\end{array}$ & $\begin{array}{c}\text { Slope } \\
\text { Lengt } \\
\text { h }\end{array}$ & $\begin{array}{c}\text { Upslop } \\
\text { Length }\end{array}$ \\
\hline $\begin{array}{l}7 \\
\text { percen } \\
t\end{array}$ & $\begin{array}{l}636.5 \\
\text { meters }\end{array}$ & $220^{\circ}$ & & & & & & & & \\
\hline
\end{tabular}

Oi --- 0 to 3 centimeters; very dark brown (10YR 2/2) moist, slightly decomposed plant material; structureless structure; very friable; clear wavy boundary.

Oe --- 3 to 6 centimeters; very dark brown (10YR 2/2) moist, broken face, moderately decomposed plant material; weak medium granular structure; very friable; clear wavy boundary.

A --- 6 to 10 centimeters; very dark grayish brown (10YR 3/2) moist, broken face, silt loam; weak medium granular structure; very friable; very strongly acid, $\mathrm{pH} 4.5$; clear wavy boundary.

BE --- 10 to 17 centimeters; yellowish brown (10YR 5/4) moist, broken face, silt loam; weak fine subangular blocky parting to moderate fine granular structure; friable; clear wavy boundary.

Bt1 --- 17 to 25 centimeters; brownish yellow (10YR 6/6) moist, broken face, silt loam; moderate fine subangular blocky structure; firm; 35 percent (common) continuous distinct yellowish brown (10YR 5/4), moist, clay films on all faces of peds; gradual wavy boundary.

Bt2 --- 25 to 52 centimeters; brownish yellow (10YR 6/8) moist, broken face, silty clay loam; moderate medium subangular blocky structure; firm; 35 percent (common) continuous distinct yellowish brown (10YR 5/4), moist, clay films on all faces of peds; 1 percent (few) fine faint light yellowish brown (10YR 6/4), moist, iron depletions throughout and 1 percent (few) fine distinct light gray (10YR 7/2), moist, iron depletions throughout; very strongly acid, $\mathrm{pH} 4.5$; gradual wavy boundary.

Btx1 --- 52 to 72 centimeters; light yellowish brown (10YR 6/4) moist, broken face, silt loam; strong medium prismatic parting to weak medium platy structure; very firm; 35 percent (common) continuous faint pale brown (10YR 6/3), moist, clay films on vertical faces of peds and 35 percent (common) continuous faint pale brown (10YR 6/3), moist, clay films on top faces of peds; 10 percent (common) medium distinct brownish yellow (10YR 6/8), moist, ironmanganese masses in matrix and 10 percent (common) medium distinct light gray (10YR 7/2), moist, iron depletions in matrix; gradual wavy boundary. 
Btx2 --- 72 to 116 centimeters; light gray (10YR 7/2) moist, broken face, channery loam; moderate medium prismatic structure; very firm; 35 percent (common) continuous faint pale brown (10YR 6/3), moist, clay films on all faces of peds; 40 percent (many) medium distinct 35 percent brownish yellow (10YR 6/8), moist and 5 percent light yellowish brown (10YR $6 / 4$ ), moist, iron-manganese masses on vertical faces of peds; gradual wavy boundary.

Btx3 --- 116 to 150 centimeters; light gray (10YR 7/2) moist, broken face, silty clay loam; strong medium prismatic structure; very firm; 10 percent (few) continuous distinct pale brown (10YR 6/3), moist, clay films on vertical faces of peds; 20 percent (many) medium distinct brownish yellow (10YR 6/8), moist, iron-manganese masses on vertical faces of peds; very strongly acid, $\mathrm{pH} 4.5$. 


\subsubsection{Pedon Description Site Footslope (north)}

Site Record ID: 24

Pedon Record ID: 26

Pedon ID: S09WV167-520

Site ID: S09WV167-520

Lab Pedon \#:S09WV167-520

Description Date: 7/28/2009

Print Date: 8/8/2009

Describer: NOLL

Site Notes: Pedon Notes: Soil Name As Described/Sampled: Buchanan-like

Soil Name As Correlated:

Classification:

Pedon Type:

Pedon Purpose:

Taxon Kind:

SSURGO MU:

Lat/Long: $39^{\circ} 38^{\prime} 57.1^{\prime \prime}$ north, $79^{\circ} 47^{\prime} 25.1$ " west

UTM: 603787.08E, 4389521.57N -- Datum NAD83, Zone 17

Location Description:

Legal Description:

Landscape:

Landform:

Microfeature:

Anthropogenic Feature:

Geomorphic Component: Base Slope

Profile Pos: Footslope

Slope: 10 percent

Elevation: 635.9 meters

Aspect: $2^{\circ}$

Shape: up/down: Concave; across: Linear

Complexity: Simple

Flooding:

Ponding:

Drainage:

Runoff:

Permeability:

Erosion:

Primary Earth Cover: ; Secondary Earth Cover:

Parent Materials: 


\section{Bedrock:}

\section{Particle Size Control Section:}

\begin{tabular}{|l|l|l|l|l|l|l|l|l|l|l|}
\hline Slope & $\begin{array}{c}\text { Elevatio } \\
\mathbf{n}\end{array}$ & $\begin{array}{c}\text { Aspec } \\
\mathbf{t}\end{array}$ & $\begin{array}{c}\text { MAA } \\
\mathbf{T}\end{array}$ & $\begin{array}{c}\text { MSA } \\
\mathbf{T}\end{array}$ & $\begin{array}{c}\text { MWA } \\
\mathbf{T}\end{array}$ & $\begin{array}{c}\text { MA } \\
\mathbf{P}\end{array}$ & $\begin{array}{c}\text { Frost } \\
\text {-Free } \\
\text { Days }\end{array}$ & $\begin{array}{c}\text { Drainag } \\
\text { e Class }\end{array}$ & $\begin{array}{c}\text { Slope } \\
\text { Lengt } \\
\text { h }\end{array}$ & $\begin{array}{c}\text { Upslop } \\
\text { Length }\end{array}$ \\
\hline $\begin{array}{l}10 \\
\text { percen } \\
\mathrm{t}\end{array}$ & $\begin{array}{l}635.9 \\
\text { meters }\end{array}$ & $22^{\circ}$ & & & & & & & & \\
\hline
\end{tabular}

O --- 0 to 3 centimeters; very dark brown (10YR 2/2) moist, slightly decomposed plant material; structureless structure; very friable; clear wavy boundary.

A --- 3 to 10 centimeters; dark grayish brown (10YR 4/2) moist, silt loam; moderate medium granular parting to moderate fine granular structure; very friable; common very fine roots throughout, common fine roots throughout, common medium roots throughout and common coarse roots throughout; 5 percent flat subangular strongly cemented 2 to 75 millimeters sandstone fragments; very strongly acid, $\mathrm{pH} 4.5$; clear wavy boundary.

BA --- 10 to 18 centimeters; yellowish brown (10YR 5/4) moist, silt loam; moderate medium subangular blocky parting to moderate fine subangular blocky structure; friable; common very fine roots throughout, common fine roots throughout and common medium roots throughout; 5 percent flat subangular strongly cemented 2 to 150 millimeters sandstone fragments; clear wavy boundary.

Bt1 --- 18 to 38 centimeters; yellowish brown (10YR 5/6) moist, silty clay loam; moderate medium subangular blocky parting to moderate fine subangular blocky structure; firm; common fine roots throughout and common very fine roots throughout; 35 percent (common) continuous faint yellowish brown (10YR 5/4), moist, clay films on all faces of peds; 2 percent nonflat subrounded moderately cemented 2 to 75 millimeters sandstone fragments and 2 percent flat subangular strongly cemented 2 to 150 millimeters sandstone fragments; gradual wavy boundary.

Bt2 --- 38 to 65 centimeters; brownish yellow (10YR 6/6) moist, silty clay; moderate fine subangular blocky parting to weak fine platy structure; firm; common fine roots throughout and common very fine roots throughout; 35 percent (common) continuous faint yellowish brown (10YR 5/4), moist, clay films on all faces of peds; 15 percent (common) coarse distinct light gray (10YR 7/2), moist, iron depletions in matrix; 8 percent nonflat subrounded moderately cemented 2 to 75 millimeters sandstone fragments; very strongly acid, $\mathrm{pH} 4.5$; gradual wavy boundary.

Btx1 --- 65 to 74 centimeters; yellowish brown (10YR 5/6) moist, gravelly clay loam; moderate medium prismatic parting to weak fine platy structure; firm; common very fine roots between peds; 35 percent (common) continuous faint pale brown (10YR 6/3), moist, clay films on top faces of peds and 35 percent (common) continuous faint pale brown (10YR 6/3), moist, clay films on vertical faces of peds; 5 percent (common) medium black (10YR 2/1), moist, 
iron-manganese concretions throughout, 15 percent (common) coarse brownish yellow (10YR 6/8), moist, iron-manganese masses in matrix and 15 percent (common) coarse light gray (10YR 7/2), moist, iron depletions in matrix; 15 percent flat subangular strongly cemented 2 to 150 millimeters sandstone fragments; clear wavy boundary.

Btx2 --- 74 to 110 centimeters; light yellowish brown (10YR 6/4) moist, clay loam; moderate medium prismatic parting to moderate medium platy structure; very firm; common very fine roots between peds; 35 percent (common) continuous faint pale brown (10YR 6/3), moist, clay films on vertical faces of peds; 3 percent flat subangular strongly cemented 2 to 150 millimeters sandstone fragments and 10 percent nonflat subrounded moderately cemented 2 to 75 millimeters sandstone fragments; clear wavy boundary.

Btx3 --- 110 to 150 centimeters; brownish yellow (10YR 6/8) moist, gravelly clay loam; strong medium prismatic structure; very firm; 10 percent (few) continuous faint pale brown (10YR 6/3), moist, clay films on vertical faces of peds; 25 percent nonflat subrounded moderately cemented 2 to 75 millimeters sandstone fragments; very strongly acid, $\mathrm{pH} 4.5$. 


\subsubsection{Pedon Description Site Backslope (north)}

Site Record ID: 25

Pedon Record ID: 27

Pedon ID: S09WV167-530

Site ID: S09WV167-530

Lab Pedon \#:S09WV167-530

Description Date: 7/28/2009

Print Date: 8/10/2009

Describer: NOLL

Site Notes: Pedon Notes: Soil Name As Described/Sampled: Buchanan

Soil Name As Correlated:

Classification:

Pedon Type:

Pedon Purpose:

Taxon Kind:

SSURGO MU:

Lat/Long: 39³8'51.9” north, 7947'29.4” west

UTM: 603696.46E, 4389344.65N -- Datum NAD83, Zone 17

Location Description:

Legal Description:

Landscape:

Landform:

Microfeature:

Anthropogenic Feature:

Geomorphic Component: Side Slope

Profile Pos: Backslope: on upper third

Slope: 16 percent

Elevation: 666 meters

Aspect: $302^{\circ}$

Shape: up/down: Convex; across: Linear

Complexity: Simple

Flooding:

Ponding:

Drainage:

Runoff:

Permeability:

Erosion:

Primary Earth Cover: ; Secondary Earth Cover:

Parent Materials: 


\section{Bedrock:}

\section{Particle Size Control Section:}

\begin{tabular}{|l|l|l|l|l|l|l|l|l|l|l|}
\hline Slope & $\begin{array}{c}\text { Elevatio } \\
\mathbf{n}\end{array}$ & $\begin{array}{c}\text { Aspec } \\
\mathbf{t}\end{array}$ & $\begin{array}{c}\text { MAA } \\
\mathbf{T}\end{array}$ & $\begin{array}{c}\text { MSA } \\
\mathbf{T}\end{array}$ & $\begin{array}{c}\text { MWA } \\
\mathbf{T}\end{array}$ & $\begin{array}{c}\text { MA } \\
\mathbf{P}\end{array}$ & $\begin{array}{c}\text { Frost } \\
\text {-Free } \\
\text { Days }\end{array}$ & $\begin{array}{c}\text { Drainag } \\
\text { e Class }\end{array}$ & $\begin{array}{c}\text { Slope } \\
\text { Lengt } \\
\text { h }\end{array}$ & $\begin{array}{c}\text { Upslop } \\
\text { Length }\end{array}$ \\
\hline $\begin{array}{l}16 \\
\text { percen } \\
\mathrm{t}\end{array}$ & $\begin{array}{l}666 \\
\text { meters }\end{array}$ & $302^{\circ}$ & & & & & & & & \\
\hline
\end{tabular}

Oi --- 0 to 3 centimeters; very dark brown (10YR 2/2) moist, slightly decomposed plant material; structureless structure; very friable; common coarse roots throughout, common medium roots throughout, common fine roots throughout and common very fine roots throughout; abrupt wavy boundary.

A --- 3 to 8 centimeters; very dark grayish brown (10YR 3/2) moist, silt loam; weak medium granular structure; friable; common coarse roots throughout, common medium roots throughout, common fine roots throughout and common very fine roots throughout; 2 percent nonflat subrounded moderately cemented 2 to 75 millimeters sandstone fragments; clear wavy boundary.

BA --- 8 to 17 centimeters; brown (10YR 4/3) moist, silt loam; weak medium subangular blocky parting to moderate fine granular structure; friable; common medium roots throughout, common fine roots throughout and common very fine roots throughout; 2 percent nonflat subrounded moderately cemented 2 to 75 millimeters sandstone fragments; clear wavy boundary.

Bt1 --- 17 to 33 centimeters; light yellowish brown (10YR 6/4) moist, silty clay loam; moderate medium subangular blocky structure; friable; common fine roots throughout and common very fine roots throughout pores; 35 percent (common) continuous faint yellowish brown (10YR 5/4), moist, clay films on all faces of peds; 5 percent nonflat subrounded moderately cemented 2 to 75 millimeters sandstone fragments; clear wavy boundary.

Bt2 --- 33 to 58 centimeters; yellowish brown (10YR 5/6) moist, silty clay loam; strong medium subangular blocky structure; firm; common fine roots between peds and common very fine roots between peds; 35 percent (common) continuous faint yellowish brown (10YR 5/4), moist, clay films on all faces of peds; 2 percent (common) medium distinct light gray (10YR $7 / 2$ ), moist, iron depletions in matrix and 2 percent (common) medium faint brownish yellow (10YR 6/8), moist, iron-manganese masses in matrix; 4 percent flat subangular strongly cemented 2 to 150 millimeters sandstone fragments and 4 percent nonflat subrounded moderately cemented 2 to 75 millimeters sandstone fragments; clear wavy boundary.

Btx1 --- 58 to 72 centimeters; light gray (10YR 7/2) moist, silty clay; strong medium prismatic parting to strong medium subangular blocky structure; firm; common very fine roots between peds; 35 percent (common) continuous faint brown (10YR 5/3), moist, clay films on vertical faces of peds and 35 percent (common) continuous faint brown (10YR 5/3), moist, clay films 
on top faces of peds; 2 percent (common) medium distinct light gray (10YR 7/2), moist, iron depletions on vertical faces of peds and 2 percent (common) medium distinct brownish yellow (10YR 6/8), moist, iron-manganese masses on vertical faces of peds; 4 percent flat subangular strongly cemented 2 to 150 millimeters sandstone fragments and 4 percent nonflat subrounded moderately cemented 2 to 75 millimeters sandstone fragments; gradual wavy boundary.

Btx2 --- 72 to 96 centimeters; grayish brown (10YR 5/2) moist, silty clay; moderate medium prismatic structure; very firm; 35 percent (common) continuous faint brown (10YR 5/3), moist, clay films on vertical faces of peds; 7 percent (common) medium faint light gray (10YR 7/2), moist, iron depletions on vertical faces of peds and 8 percent (common) medium distinct brownish yellow (10YR 6/8), moist and, iron-manganese masses on vertical faces of peds; 5 percent flat subangular strongly cemented 2 to 150 millimeters sandstone fragments and 5 percent nonflat subrounded moderately cemented 2 to 75 millimeters sandstone fragments; gradual wavy boundary.

Btx3 --- 96 to 123 centimeters; brownish yellow (10YR 6/8) moist, silty clay; moderate medium prismatic structure; very firm; 10 percent (few) continuous faint pale brown (10YR 6/3), moist, clay films on vertical faces of peds; 20 percent (many) medium light gray (10YR $7 / 2$ ), moist, iron depletions on vertical faces of peds; 5 percent flat subangular strongly cemented 2 to 150 millimeters sandstone fragments and 5 percent nonflat subrounded moderately cemented 2 to 75 millimeters sandstone fragments; gradual wavy boundary.

Btx4 --- 123 to 150 centimeters; light gray (10YR 7/2) moist, silty clay; strong medium prismatic structure; very firm; 10 percent (few) continuous faint pale brown (10YR 6/3), moist, clay films on vertical faces of peds; 20 percent (many) medium distinct light brownish gray (10YR 6/2), moist, iron depletions on vertical faces of peds; 5 percent flat subangular strongly cemented 2 to 150 millimeters sandstone fragments and 5 percent nonflat subrounded moderately cemented 2 to 75 millimeters sandstone fragments. 


\subsubsection{Pedon Description Site Summit (north)}

Site Record ID: 27

Pedon Record ID: 29

Pedon ID: S09WV167-540

Site ID: S09WV167-540

Lab Pedon \#:S09WV167-540

Description Date: 7/28/2009

Print Date: 8/8/2009

Describer:

Site Notes: Pedon Notes:

Soil Name As Described/Sampled: Gilpin

Soil Name As Correlated:

Classification:

Pedon Type:

Pedon Purpose:

Taxon Kind:

SSURGO MU:

Lat/Long: 39³8'48.4” north, 7947'28.9” west

UTM: 603692.96E, 4389252.05N -- Datum NAD83, Zone 17

Location Description:

Legal Description:

Landscape:

Landform:

Microfeature:

Anthropogenic Feature:

Geomorphic Component: Interfluve

Profile Pos: Summit: on lower third

Slope: 7 percent

Elevation: 676.2 meters

Aspect: $292^{\circ}$

Shape: up/down: Linear; across: Convex

Complexity:

Flooding:

Ponding:

Drainage:

Runoff:

Permeability:

Erosion:

Primary Earth Cover: ; Secondary Earth Cover:

Parent Materials: 
Bedrock: Moderately cemented shale at 108 centimeters

Particle Size Control Section:

\begin{tabular}{|l|l|l|l|l|l|l|l|l|l|l|}
\hline Slope & $\begin{array}{c}\text { Elevatio } \\
\mathbf{n}\end{array}$ & $\begin{array}{c}\text { Aspec } \\
\mathbf{t}\end{array}$ & $\begin{array}{c}\text { MAA } \\
\mathbf{T}\end{array}$ & $\begin{array}{c}\text { MSA } \\
\mathbf{T}\end{array}$ & $\begin{array}{c}\text { MWA } \\
\mathbf{T}\end{array}$ & $\begin{array}{c}\text { MA } \\
\mathbf{P}\end{array}$ & $\begin{array}{c}\text { Frost } \\
\text {-Free } \\
\text { Days }\end{array}$ & $\begin{array}{c}\text { Drainag } \\
\text { e Class }\end{array}$ & $\begin{array}{c}\text { Slope } \\
\text { Lengt } \\
\text { h }\end{array}$ & $\begin{array}{c}\text { Upslop } \\
\text { Length }\end{array}$ \\
\hline $\begin{array}{l}l \\
\text { percen } \\
\mathrm{t}\end{array}$ & $\begin{array}{l}676.2 \\
\text { meters }\end{array}$ & $292^{\circ}$ & & & & & & & & \\
\hline
\end{tabular}

Oi --- 0 to 6 centimeters; very dark brown (10YR 2/2) moist, highly decomposed plant material; structureless structure; very friable; abrupt smooth boundary.

A --- 6 to 14 centimeters; very dark grayish brown (10YR 3/2) moist, silt loam; weak fine granular structure; very friable; common fine roots throughout and common very fine roots throughout; 2 percent nonflat subrounded moderately cemented 2 to 75 millimeters sandstone fragments; extremely acid, $\mathrm{pH} 4.3$; clear wavy boundary.

BA --- 14 to 22 centimeters; dark yellowish brown (10YR 4/4) moist, silt loam; weak medium subangular blocky parting to weak medium granular structure; friable; common coarse roots throughout, common medium roots throughout, common fine roots throughout and common very fine roots throughout; 2 percent nonflat subrounded moderately cemented 2 to 75 millimeters sandstone fragments; clear wavy boundary.

Bt1 --- 22 to 50 centimeters; dark yellowish brown (10YR 4/6) moist, silty clay loam; moderate medium subangular blocky structure; firm; common medium roots throughout, common fine roots throughout and common very fine roots throughout pores; 35 percent (common) continuous faint yellowish brown (10YR 5/4), moist, clay films on all faces of peds; 5 percent flat subangular strongly cemented 2 to 75 millimeters sandstone fragments; extremely acid, $\mathrm{pH} 4.3$; clear wavy boundary.

Bt2 --- 50 to 60 centimeters; dark yellowish brown (10YR 4/6) moist, channery silty clay loam; moderate medium subangular blocky structure; firm; common fine roots throughout and common very fine roots throughout; 35 percent (common) continuous faint yellowish brown (10YR 5/4), moist, clay films on all faces of peds; 15 percent flat subangular strongly cemented 2 to 75 millimeters sandstone fragments; clear wavy boundary.

BC --- 60 to 68 centimeters; dark yellowish brown (10YR 4/6) moist, channery silt loam; moderate medium subangular blocky structure; very firm; common fine roots in cracks and common very fine roots in cracks; 45 percent (many) medium distinct light gray (10YR 7/1), moist, iron depletions on faces of peds; 15 percent flat subangular strongly cemented 2 to 75 millimeters sandstone fragments; extremely acid, $\mathrm{pH} 4.3$; abrupt smooth boundary.

Cr --- 68 to 108 centimeters; dark yellowish brown (10YR 4/6) moist; massive; very firm; low excavation difficulty; clear smooth boundary. 
$\mathbf{R}$--- 108 centimeters; extremely firm; moderate excavation difficulty.

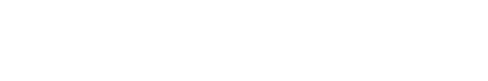 \\ Virginia University Libraries,
ou=Acquisitions Department,

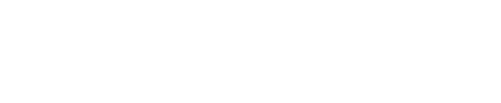

